\title{
Flooding and reequilibration of a series of Pittsburgh bed underground coal mines, 1980 to 2015
}

David D. M. Light

Follow this and additional works at: https://researchrepository.wvu.edu/etd

\section{Recommended Citation}

Light, David D. M., "Flooding and reequilibration of a series of Pittsburgh bed underground coal mines, 1980 to 2015" (2016). Graduate Theses, Dissertations, and Problem Reports. 6088.

https://researchrepository.wvu.edu/etd/6088

This Dissertation is protected by copyright and/or related rights. It has been brought to you by the The Research Repository @ WVU with permission from the rights-holder(s). You are free to use this Dissertation in any way that is permitted by the copyright and related rights legislation that applies to your use. For other uses you must obtain permission from the rights-holder(s) directly, unless additional rights are indicated by a Creative Commons license in the record and/ or on the work itself. This Dissertation has been accepted for inclusion in WVU Graduate Theses, Dissertations, and Problem Reports collection by an authorized administrator of The Research Repository @ WVU.

For more information, please contact researchrepository@mail.wvu.edu. 


\title{
FLOODING AND REEQUILIBRATION OF A SERIES OF PITTSBURGH BED UNDERGROUND COAL MINES, 1980 to 2015
}

\author{
David D. M. Light \\ Dissertation submitted \\ to the Department of Geology and Geography \\ at West Virginia University
}

in partial fulfillment of the requirements for the degree of

Doctor of Philosophy in

Geology

Joseph J. Donovan, Ph.D., Chair

Frank Borsuk, Ph.D.

John Renton, Ph.D.

Dorothy Vesper, Ph.D.

Timothy Warner, Ph.D.

Department of Geology and Geography

Morgantown, West Virginia

2015

Keywords: Mining Hydrogeology, Mine Porosity, Mine Inflow Copyright 2015 David D. M. Light 


\begin{abstract}
Flooding and Reequilibration of a Series of Pittsburgh Bed Underground Coal Mines, 1980 to 2015

David D. M. Light
\end{abstract}

This study examines the water-level elevation history of selected flooding and flooded underground mines in the Pittsburgh coal basin of SW Pennsylvania from the time of closure until post-flooding pool-level reequilibration. Mines within this mining district developed pools with nearly steady-state groundwater flow within 10 to 50 years after closure. Equilibrated pool levels within each of the mines were controlled by various combinations of spillage to the surface or other mines, pumpage, and barrier leakage. In a study of flooding in the Clarksville, PA area, field water-level observations, mine geometry, barrier hydraulic conductivity, recharge rates, and late-stage storage gains were parameterized to match known pumping rates and develop a fluid mass balance. Vertical infiltration (recharge and leakage) estimates were developed using a depth-dependent model based on the assumption that most vertical infiltration is focused in areas with $<75 \mathrm{~m}$ of overburden. A MODFLOW simulation of the nearly steadystate flow conditions was calibrated to hydraulic heads in observation wells and to known pumping rates by varying barrier hydraulic conductivity. The calibrated model suggests significant head-driven leakage between adjacent mines, both horizontally through coal barriers and vertically through interburden into an overlying mine. Calibrated barrier hydraulic conductivities were significantly greater than literature values for other mines at similar depths in the region. This suggests that some barriers may be hydraulically compromised by un-mapped entries, horizontal boreholes, or similar features that act to interconnect mines. These model results suggest that post-mining inter-annual equilibrium conditions are amenable to quantitative description using mine maps, sparse observation-well data, accurately-estimated pumping rates, and depth-dependent vertical infiltration estimates. Results are applicable to planning for postflooding water control schemes, although hydraulic testing may be required to verify model results.

In a second study of a nearby area, three mines were mapped to determine mining type distribution (longwall, etc.) and these mining-type areas assigned typical porosity values based on industry-standard extraction ratios. The porosity estimates were plotted against coal-base elevation contours to model the hypsometric distribution of porosity. Using pumping rates from active operations and these hypsometric porosities, the approximate duration of flooding was estimated for two of the mines; these overestimate the actual (observed) flooding time by 200$275 \%$. On the other hand, mine inflow rates estimated using observed water levels and the porosity model indicate temporal changes in the fluid mass balance for each mine that are consistent with spillage and/or barrier leakage between mines interpreted from water-level hydrographs. Results indicate that accurate prediction of the duration of mine flooding requires explicit consideration of groundwater conditions in adjacent mines and the potential for barrier leakage. 


\section{ACKNOWLEDGEMENTS}

I would like to express my gratitude to Dr. Joe Donovan whose enduring patience and encouragement allowed me to complete this manuscript. Eberhard Werner and the late Bruce Leavitt provided insight into various aspects of mining and mine hydrology. Information regarding mine operations was provided by Joe Lapkowicz, former mining engineer in Gateway mine. Ken Dufalla, President of the Izaak Walton League of Greene County, shared observations on the location and timing of surface discharges from Clyde and Pitt Gas mines. T. D. Light, J. Hawkins, and two anonymous reviewers provided comments that improved Chapter 3 


\section{TABLE OF CONTENTS}

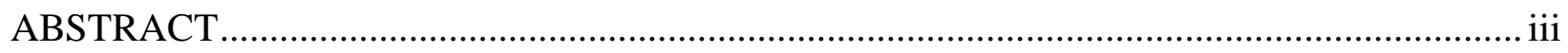

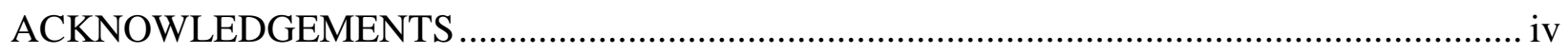

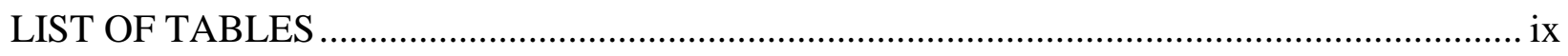

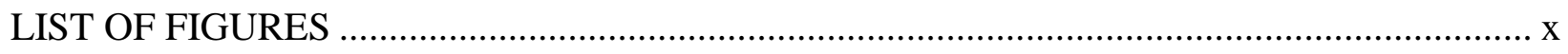

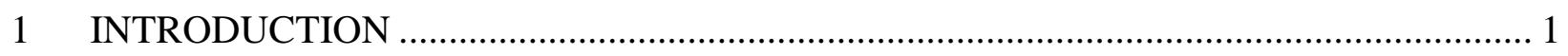

1.1 Groundwater Reequilibration in Underground Mines .................................................. 1

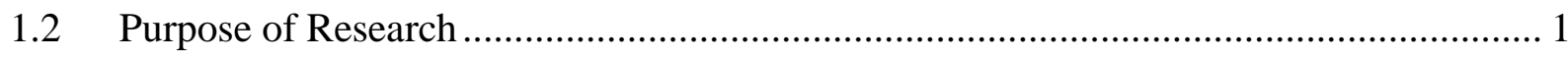

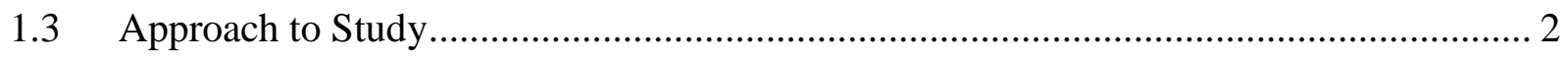

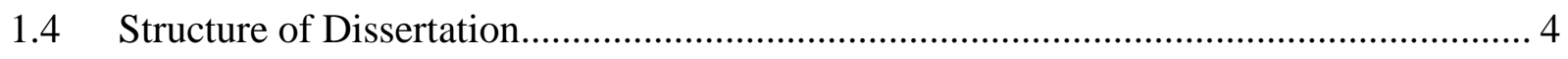

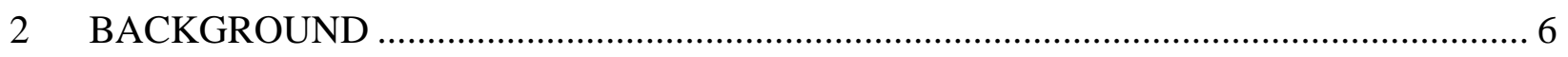

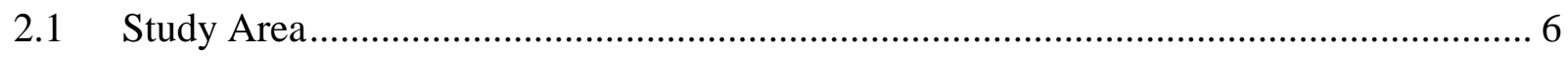

2.1.1 Location, Physiographic Description, and Climate ................................................ 6

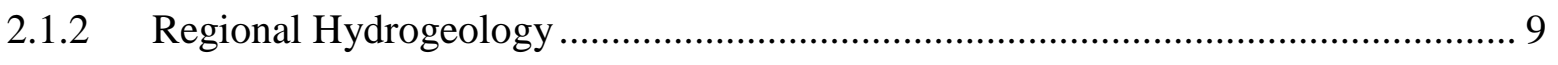

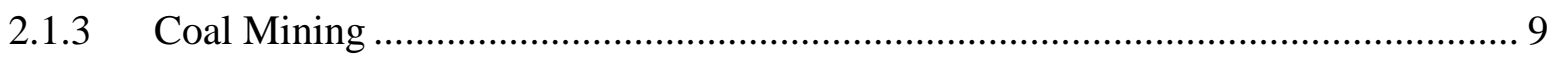

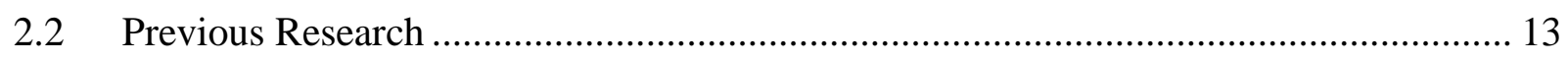

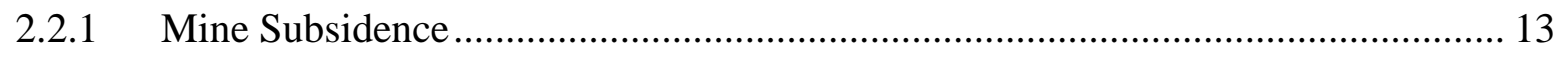

2.2.2 Mine Flooding/Mine Hydrogeology ………...................................................... 15 
2.3 Conceptual Model of Coal-mine Aquifers ............................................................... 16

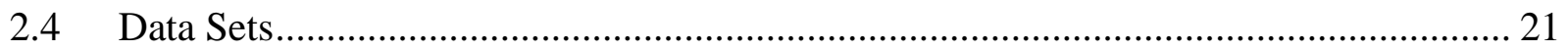

3 MINE-WATER FLOW BETWEEN CONTIGUOUS FLOODED UNDERGROUND COAL MINES WITH HYDRAULICALLY-COMPROMISED BARRIERS .................... 24

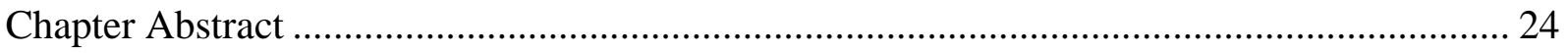

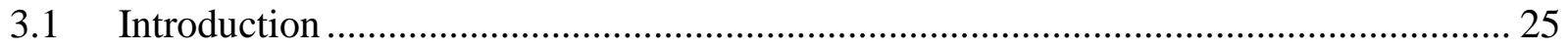

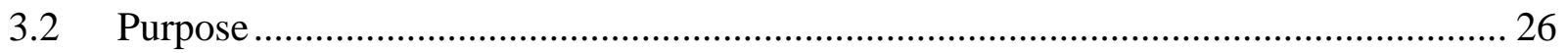

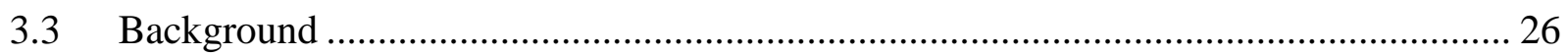

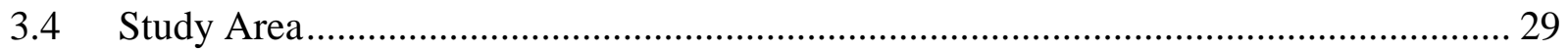

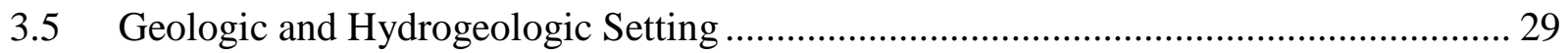

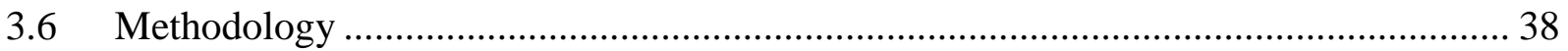

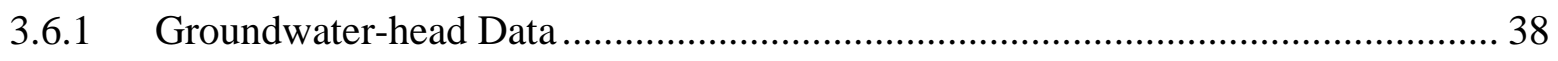

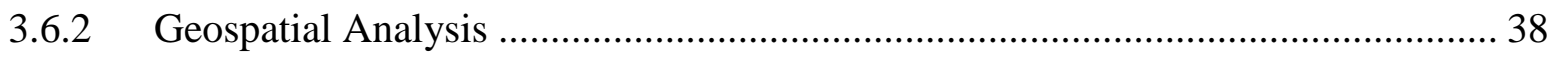

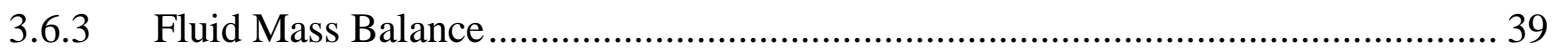

3.6.4 Groundwater-flow Model Development .......................................................... 42

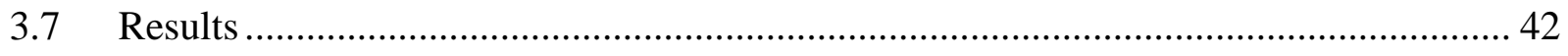

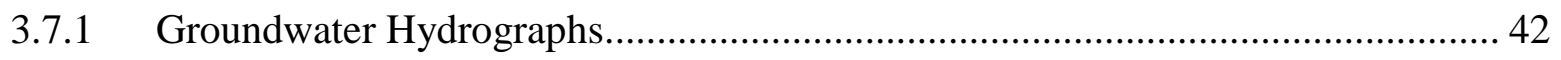

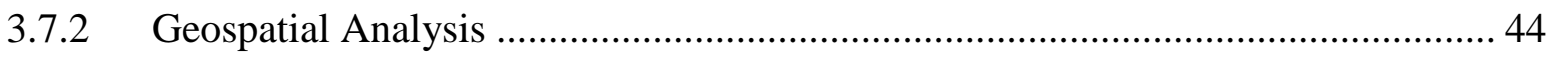

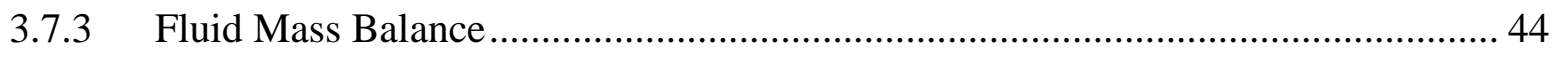




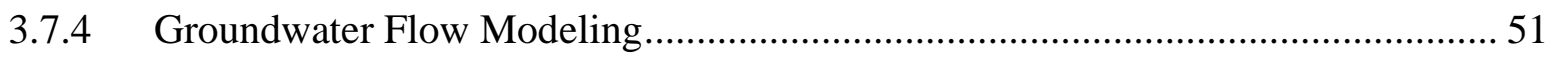

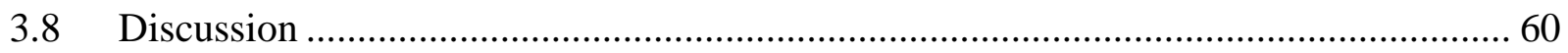

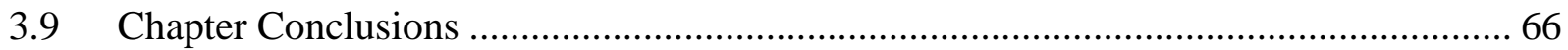

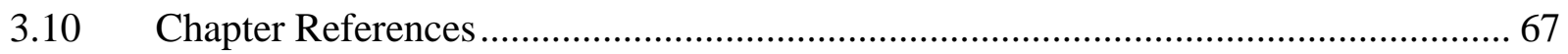

4 HYDROGRAPH ANALYSIS TO INFER FLOODING HISTORY OF A SERIES OF CONTIGUOUS, BELOW-DRAINAGE, UNDERGROUND COAL MINES, IN SOUTHWEST PENNSYLVANIA _.................................................................. 73

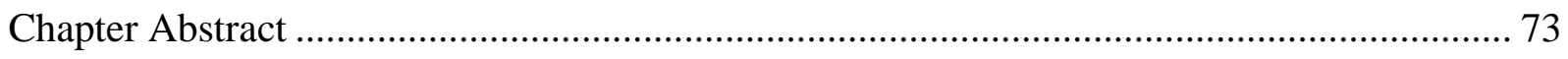

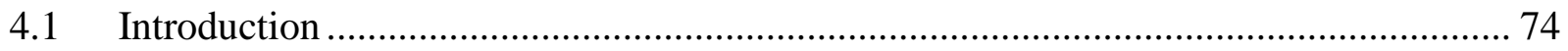

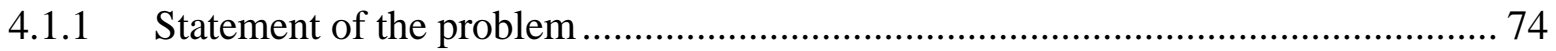

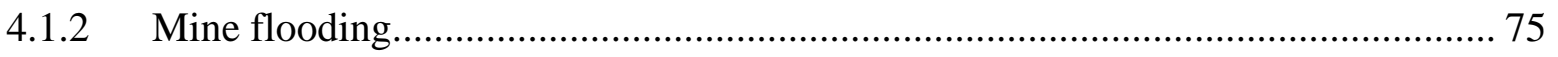

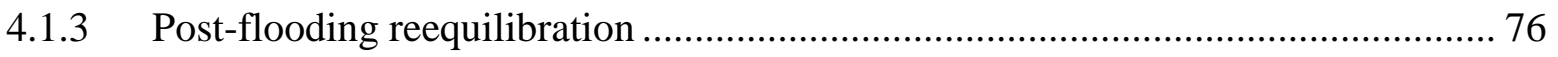

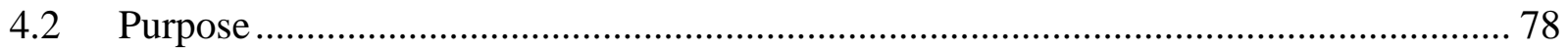

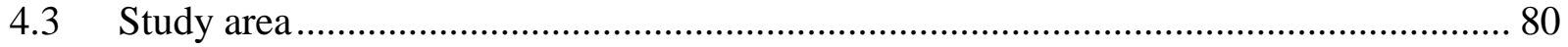

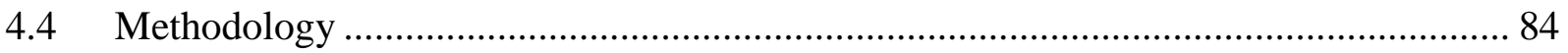

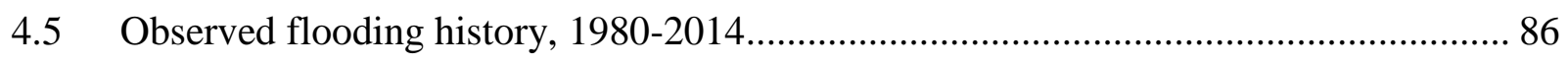

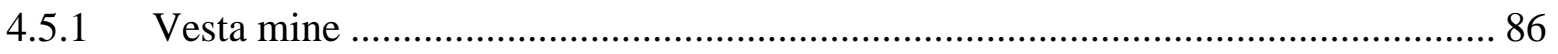

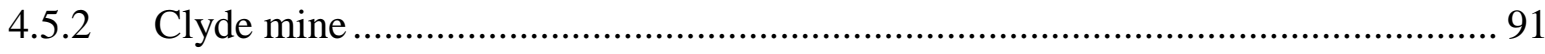

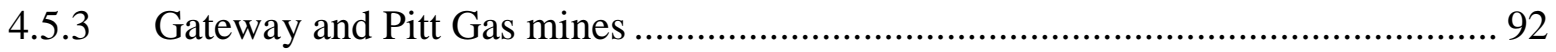




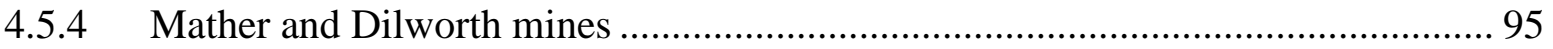

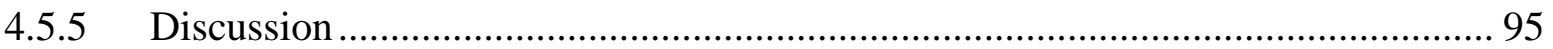

4.6 Mine porosity and flooding-duration models ...................................................... 97

4.6.1 Hypsometric model of pore volume ............................................................. 98

4.6.2 Flooding duration and rate models ......................................................... 101

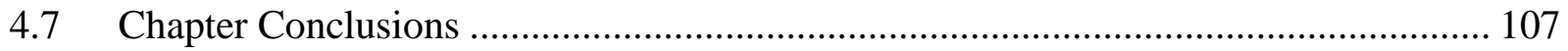

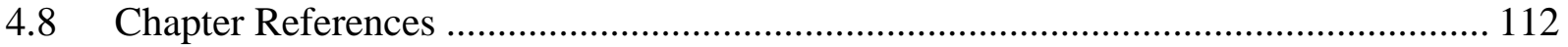

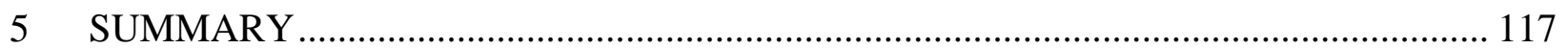

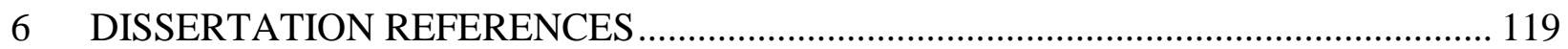




\section{LIST OF TABLES}

Table 3.1. Vertical infiltration rates for regional coal mines ...............................40

Table 3.2. Mine area and overburden distribution statistics ...................................45

Table 3.3. Measured barrier dimensions (refer to Figure 3.2 for barrier locations)

Table 3.4. Vertical infiltration, pumping, storage, and leakeage rates ..................48

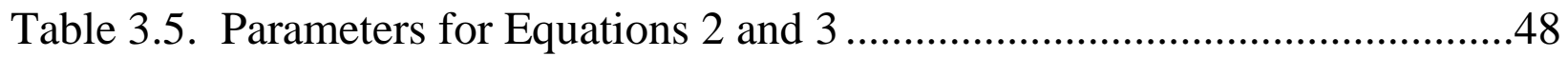

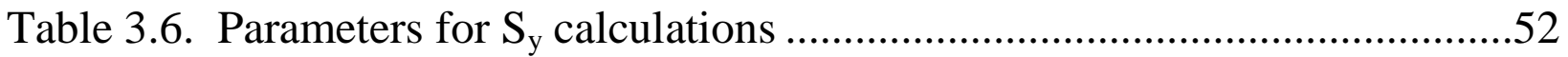

Table 3.7. Monthly (2011) extraction volumes for pumps in the study area (1000 $\left.\mathrm{m}^{3}\right)$

Table 3.8. Barrier leakage estimates for mines with multiple adjacent mines (refer to Figure 3.2 for barrier locations; refer to text for parameter definitions)

Table 3.9. Observed and modeled groundwater elevation heads in meters 59

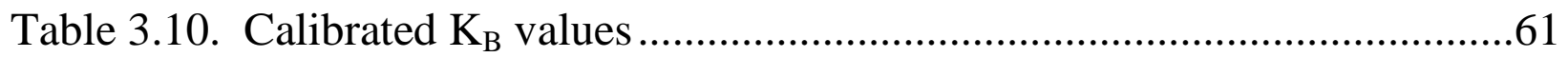

Table 4.1. Mine area, overburden statistics, and flooding dates ..........................83

Table 4.2. Monitoring well nomenclature, periods of record, and data sources ....85

Table 4.3. Estimated total pore volumes for Clyde, Gateway/Pitt Gas, and Vesta mines.

Table 4.4. Reported active-operation pumping rates 103 


\section{LIST OF FIGURES}

Figure 1.1. Conceptual model indicating areas where groundwater inflow (blue arrows) occurs primarily by recharge or leakage and areas of differing confinement by flooding level (not to scale).

Figure 2.1. The Pittsburgh coal basin (light grey) showing mines in the Pittsburgh (medium grey) and Sewickley (dark grey) seams..............7

Figure 2.2. Generalized stratigraphic column of the lower Monongahela Group (after Edmunds et al., 1999)............................................................

Figure 2.3. Plan view of typical mine showing spatial variation in mining method.....

Figure 2.4. Approximate extent of flooding as of 2015 (blue) in Pittsburgh seam mines (dark grey).

Figure 2.5. Post-mining overburden subsidence zones (after Kendorski, 1993).

Not to scale.

Figure 2.6. Cross section of coal-mine aquifer model (zones from Kendorski, 1993)

Figure 2.7. Plan view of adjacent mines showing inferred groundwater flow (arrows) from principle recharge areas (red) and through leaky barriers.

Figure 2.8. Plan view of late-stage mine flooding indicating groundwater flow toward sink that may include leaky barriers, treatment plants (triangle), and additions to confined storage (yellow arrows).

Figure 2.9. Study area showing monitoring wells (triangles), barometric pressure stations (crosses), Precipitation stations (diamonds), and USGS stream gage (square).

Figure 2.10. Monthly precipitation averaged from five stations. See figure 2.9 for station locations. 
Figure 3.1. Extent of the Pittsburgh coal seam (light shading) with areas of underground mining in the Pittsburgh (medium shading) and Sewickley (dark shading) seams, and Greene County (dashed line).30

Figure 3.2. Underground Pittsburgh-seam mines in the study area with structure contours of coal bottom (5-meter interval), locations of monitoring wells, inter-mine barriers, mine-water treatment plants, (CLY $=$ Clyde CRU = Crucible; DIL = Dilworth; Gateway $=$ GAT; HUM = Humphrey; Mather = MAT; NEM = Nemacolin; PIT = Pitt Gas; $\mathrm{ROB}=$ Robena; $\mathrm{SHA}=$ Shannopin; and WAR = Warwick \#2).

Figure 3.3. Groundwater elevations indicate fairly uniform pool levels in mines with multiple observation wells $($ CRU1 $=$ Crucible; DIL1 $=$ Dilworth; GAT1 and GAT2 = Gateway; NEM1 = Nemacolin; PIT1 = Pitt Gas; and ROB1 = Robena). The average surface elevation in the Monongahela River (Maxwell Pool) and mine-water-treatment plant control levels are indicated by arrows.

Figure 3.4. Generalized hydrostratigraphy of the Pittsburgh Formation Upper Pennsylvanian Monongahela Group (after Edmunds et al., 1997). Scale is approximate. 33

Figure 3.5. Plan view of typical mine map showing variation in mining methods, main entries, and un-mined coal (pillars). 36

Figure 3.6. Cumulative distribution of mine area versus overburden thickness. See Table 2 for overburden statistics. .46

Figure 3.7 Estimates of groundwater vertical infiltration to underground mines, fitted using Equations 2 and 3: $\mathrm{VI}(\mathrm{d})=\mathrm{VI}(0) \mathrm{d} \leq \mathrm{d} 1, \mathrm{VI}(\mathrm{d})=$ $\operatorname{VI}(0) e-\lambda(d) d>d 1$ ( $\lambda$ solid line and $\lambda_{\text {min }}$ dashed $)$. The density function (dotted line) describes overburden thickness for mines within the study area.

Figure 3.8. Vertical infiltration rates applied to the groundwater flow model. This and later maps have been rotated from geographic north to align with the model grid......................................................................54

Figure 3.9. Conceptual model of groundwater flow across leaky barriers. ..........55 
Figure 3.10. Boundary condition types and locations within the groundwater-flow model. WEL cells for storage and leakage are located in Layer 1; extraction wells, constant heads, and targets are all in Layer 3. .......57

Figure 3.11. Calibrated steady-state hydraulic heads for Layer 3. Symbology as for Figure 9.

Figure 4.1. Typical groundwater recovery curves for head-dependent (solid line) and constant-rate (dashed) mine inflows (after Younger and Adams, 1999).

Figure 4.2. Extent of the Pittsburgh coal bed (light shading), areas of underground mines in the Pittsburgh bed (medium shading), and the study area (box).

Figure 4.3. Underground Pittsburgh-seam mines (light shading), study mines (medium shading), the axis of the Belle Vernon Anticline (dotted line), monitoring wells (crosses), treatment plants (triangles), and surface discharges (red symbols). See text and Table 4.2 for descriptions; contour lines represent the base of the Pittsburgh coal, contour interval is approximately $6 \mathrm{~m}$.

Figure 4.4. Development of flooding in study area mines (pool designations: $K=$ Kefover; $G=$ Greenlee; $B=$ Berick; $R=$ Ross; $C=$ Clyde; $Z=$ Zollarsville). Also shown, crosscuts between Clyde and Gateway/Pitt Gas (red arrows), thin Vesta-Clyde barrier section, and inferred flow path for spillage from Vesta (black arrow).

Figure 4.5. Mine-pool elevation hydrograph for wells in Vesta, Clyde, Mather, Pitt Gas, and Gateway mines. Bold letters indicate time periods shown in Figure 4.4. Numbers represent events discussed in the text. Dashed line indicates interpolated data.

Figure 4.6. Average precipitation from five NCDC weather stations (Charleroi, USC00361377; Donora, USC00362190; Gray's Landing, USC00363451; Greensboro Lock and Dam, USC00363503; and Waynesburg USC00369367. See Figure 4.2 for locations. 
Figure 4.7. Recent (2013-2014) mine pool elevations for Clyde (C6), Gateway (G1, G2), and Pitt Gas (P1) mines. Dashed line is discharge in the Monongahela River. See Table 2 and text for description of annotation

Figure 4.8. Mapped mining type area polygons for Vesta, Clyde, Gateway, and Pitt Gas mines $(10 \%$ shading $=\mathrm{LW} ; 30 \%=\mathrm{HE} ; 50 \%=\mathrm{RP} ; 70 \%=$ $\mathrm{M} ; 100 \%=\mathrm{P})$. Contour interval is six $\mathrm{m}$

Figure 4.9. Cumulative pore volume distribution by contour interval in Vesta, Clyde, and Gateway/Pitt Gas mines. Contours intervals are in meters.

Figure 4.10. Predicted mine pool elevations (solid lines) for Clyde (A) and Gateway/Pitt Gas (B) assuming constant inflow rates.

Figure 4.11. Estimated mine inflow rates for Vesta, Clyde, and Gateway/Pitt Gas mines; and average annual precipitation.

Figure 4.12. Mined areas with overburden thickness less than $75 \mathrm{~m}$ thick (orange and red) in Vesta, Clyde, Gateway, and Pitt Gas mines. The mine floor is up-dip from the mine pool in the red highlighted areas hence head-dependent inflows will be at a maximum in these areas. In areas where the mine floor is below the pool elevation (orange) and the distance between surficial aquifers and the pool surface has decreased, head-dependent inflows will be reduced by the depth of flooding. 108 


\section{INTRODUCTION}

\subsection{Groundwater Reequilibration in Underground Mines}

Underground mining of coal below elevations of local drainage typically induces groundwater infiltration which must be pumped from the mines in order to provide a dry working environment. This pumpage is maintained during the life of a mine and offsets groundwater inflow from vertical infiltration, both from recharge at shallow depths and from leakage across confining layers at greater depths. Once mining is complete, pumps are turned off and the mine begins to flood (resaturate). Flooding ceases when equilibration of the underground mine aquifer is established by one or more mechanisms, such as pumping, spilling to the surface or neighboring mines (Younger and Adams, 1999), and barrier or vertical leakage to adjacent mines (Light and Donovan, 2015). This mine-pool equilibration reestablishes groundwater flow that is likely to differ from pre-mining conditions in discharge location and rate as well as in chemical composition (Booth, 1986; Banks et al., 1997; Winters et al., 1999).

\subsection{Purpose of Research}

The purpose of this investigation is to examine different mechanisms that control groundwater recovery rates and post-flooding equilibria in underground coal mines, such as mine aquifer recharge, vertical leakage, and horizontal (barrier) leakage between adjacent contiguous mines. Specific objectives of this research include:

i. estimation of mine recharge and barrier leakage rates using barrier geometry, pumping records, and observed water-level data; and 
ii. evaluation of mine flooding using mine-pool hydrographs and estimated mine porosity and inflow rates.

Observations are confined to underground coal mines within the Pittsburgh Basin (Northern Appalachian Basin) located within the Appalachian Plateaus Physiographic Province (Fenneman, 1938). The Pittsburgh Basin has been extensively deep-mined and currently numerous deep flooded and flooding mines exist. A monitoring well network utilized in this study has been established in a variety of these mines, including fully-flooded and discharging mines, flooding mines, and mines where the groundwater elevation is controlled by pumping. The monitored mines are distributed around the basin from approximately Pittsburgh, PA to Wheeling, WV to Fairmont, WV. The mines vary in depth from shallow near outcrop to deep in the central basin. This variation in location, depth, and flooding status presents a unique natural laboratory for studying flooding and barrier leakage characteristics of coal mines.

\subsection{Approach to Study}

Figure 1.1 shows a conceptual model of coal-mine aquifer groundwater movement and reequilibration processes in flooding and flooded underground coal mines. Using such a conceptual model coupled to mine-aquifer recharge models, it is possible to develop both parametric groundwater-flow models of reequilibrated mines as well as less sophisticated constant-rate-inflow flooding-duration models. Both may be used to estimate mine inflow rates during flooding. The conceptual model is based on subsidence theory (Kendorski, 1993) and on previous research that examines coal mine recharge (Winters and Capo, 2004; McDonough et al., 2005) and barrier leakage rates (McCoy et al., 2006). 


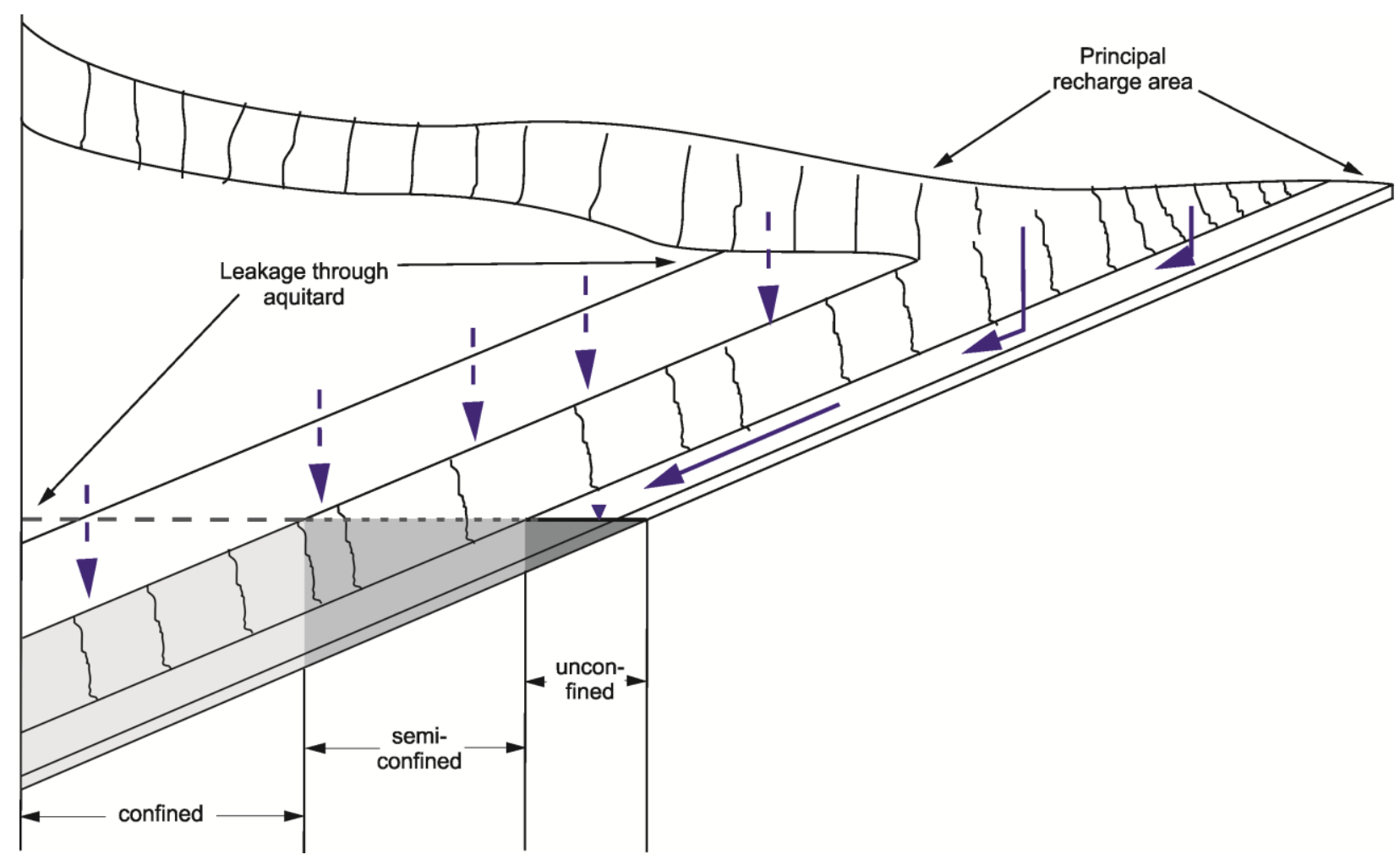

Figure 1.1. Conceptual model indicating areas where groundwater inflow (blue arrows) occurs primarily by recharge or leakage and areas of differing confinement by flooding level (not to scale). 
This research tests the hypothesis that interconnections between multiple adjacent contiguous flooding coal mines may influence the ultimate reequilibrated groundwater levels of each mine. Key factors in mine flooding are hypothesized to include the location of surface discharges, spill points, pumps, and intra-mine barrier conditions. In order to understand the relationships between different adjacent or nearby mines, this research has focused on development of:

i. conceptual models of mine aquifer geometry,

ii. fluid mass balance of mine aquifer(s),

iii. a depth-dependent recharge model,

iv. parametric groundwater flow models,

v. mine porosity/pore volume models, and

vi. mine inflow models.

In addition to hard data for flooding (e.g. water level hydrographs) such models are required to elucidate the hydraulic relationships between adjacent mines, in particular, information on the apparent barrier conditions and leakage rates between mines.

\subsection{Structure of Dissertation}

This dissertation is divided into two manuscripts that describe the aforementioned approaches to examining flooding and groundwater reequilibration phenomena in closed coal mines (Chapters 3 and 4), prefaced by a section that summarizes the relevant background and introductory material (Chapter 2), and ends with a summary of key findings and recommendations for additional new research (Chapter 5). Chapter 2 (Background) describes the study area, data collection, and field methodology. Each of the manuscripts covers a different phase of the 
research necessitating some redundancy in introductory material. Each manuscript contains its own abstract, conclusions, and references.

The scopes of the two manuscripts cover:

i. mine-water flow between contiguous flooded underground coal mines with hydraulically compromised barriers (Chapter 3); and

ii. hydrograph and fluid-mass-balance indication of complex formation in contiguous below-drainage underground coal mines (Chapter 4). 


\section{BACKGROUND}

\subsection{Study Area}

\subsubsection{Location, Physiographic Description, and Climate}

The target of this study is the Pennsylvanian-age Pittsburgh coal, which lies in the Pittsburgh Basin. The basin is defined by the outcrop of the Pittsburgh coal, covers portions of southeastern Ohio, southwestern Pennsylvanian and northern West Virginia, and extends from Pittsburgh, PA south to Charleston, WV (Figure 2.1). The basin lies within the Appalachian Plateaus Physiographic Province (Fenneman, 1938), which is characterized by relatively flat-lying sedimentary deposits and coal measures. Within the Pittsburgh Basin, rocks dip on the order of one to five degrees (Beardsley, et al., 1999). The Pittsburgh coal outcrops around the margins of the basin and is covered by $>300 \mathrm{~m}$ of overburden in the deepest portions of the basin.

The Pittsburgh coal is the basal unit of both the Pittsburgh Formation and the Monongahela Group (Figure 2.2). The Pittsburgh Formation consists of alternating layers of sandstone, limestone, dolomitic limestone, calcareous mudstones, shale, siltsone and laminites (Edmunds et al., 1999). With the exception of a channel sandstone locally overlying the Pittsburgh coal, units within the Pittsburgh Formation were deposited in low energy environments (Edmunds et al., 1999). The Pittsburgh coal averages approximately two $m$ in thickness and is relatively continuous throughout the basin (Cross, 1954).

Annual precipitation within the basin ranges from 90 to $130 \mathrm{~cm} / \mathrm{yr}$ averaging $102 \mathrm{~cm} / \mathrm{yr}$ and is almost uniformly distributed throughout the year with March and October being the wettest and 


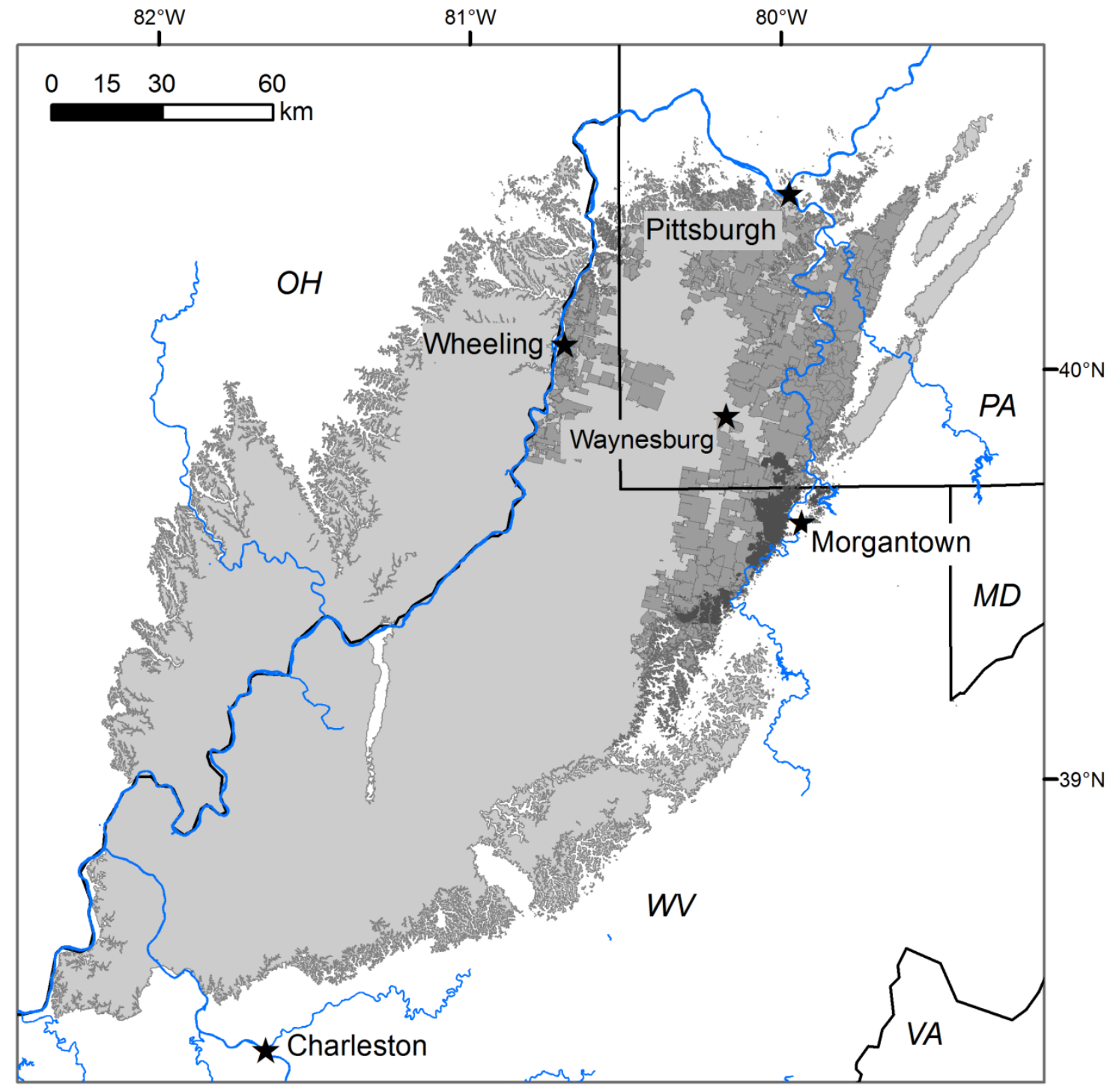

Figure 2.1. The Pittsburgh coal basin (light grey) showing mines in the Pittsburgh (medium grey) and Sewickley (dark grey) seams. 


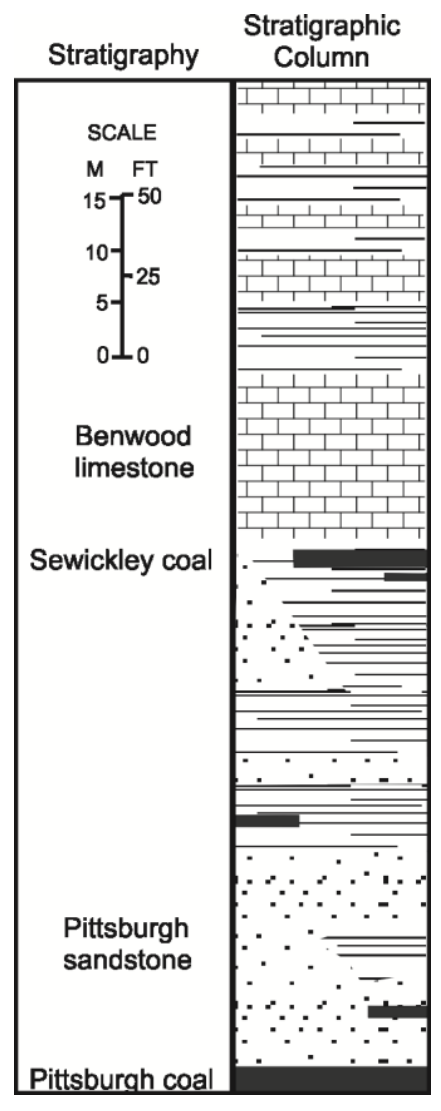

Figure 2.2. Generalized stratigraphic column of the lower Monongahela Group (after Edmunds et al., 1999). 
driest months, respectively (Rossi, 1999). Roughly one third of the precipitation that falls on the region infiltrates to groundwater, evapotranspiration consumes almost half, while the rest is stream runoff (Becher, 1971; Kozar and Mathes, 2001). The basin is drained by the Ohio River and its tributaries, while topographic relief within the basin typically is on the order of several hundred meters.

\subsubsection{Regional Hydrogeology}

The distribution and amount of infiltrating precipitation is governed by geology, topography, soils, and vegetation (Smith, 1986). Rocks in the Appalachian Plateau are primarily sedimentary and tend to have low primary permeability except in the weathering zone close to the surface. Groundwater flow through these rocks tends to be along secondary permeability: joints, fractures, bedding plane separations, and coal cleat (Schubert, 1980; Wunsch, 1993). Wyrick and Borchers (1981) found that in a typical Appalachian valley, stress-relief fractures occurs along the sides and bottom of the valley, causing permeability to be much greater than along the axis of uplands or deep below the valley floor. Hydraulic conductivity (Stoner, 1983; Bruhn, 1986) and storativity (Stoner, 1983) similarly decrease with depth. Much of the Appalachian Plateau has been deep-mined, creating anthropogenic aquifers that exert profound effects upon pre-mining groundwater conditions (Stoner, 1983; Callaghan et al., 1998).

\subsubsection{Coal Mining}

The Pittsburgh coal has been extensively mined and as of 2015, much of the coal reserves in the northern portion of the basin have been exhausted (Figure 2.1). Mining in the Pittsburgh coal bed began in the late 1700s in the vicinity of Pittsburgh, PA (Leavitt, 1999) with early mining 
occurring near outcrop and proceeding through time into deeper areas of the basin. Initially coal was mined by the "hand-loading" method wherein relatively long narrow passageways are separated by equally long and narrow areas of unmined coal. Hand loading was replaced by the room-and-pillar method whereby "rooms" are cut into the coal and "pillars" are left behind to support overburden (Figure 2.3). On completion of mining, pillars were commonly "robbed" (removed to below the volume required for roof support) on retreat from the mine workings. This removal of roof support promotes surface subsidence and collapse of overburden into the mine. Even when pillars are not removed, collapse of overburden may occur, albeit more slowly (Peng, 1986). Longwall mining methods, which became popular in the 1970s, use mechanical roof supports adjacent to the working face. Subsidence and collapse of roof materials into the mine immediately follows advance of the face and roof supports (Peng and Chiang, 1984). Longwall panels are typically separated by "mains," which are areas of rooms and pillars that serve as both haulage ways for mined coal and passages for fresh air ventilation (Figure 2.3; Peng and Chiang, 1984). Several models that predict the effects of coal mining on groundwater have been proposed (Booth, 1986; Kendorski, 1993; Peng, 2006).

Most of the historic mines in the Pittsburgh coal basin have closed and are in various stages of flooding as of 2015 (Figure 2.4). Upon mine closure, mine-water extraction pumps are turned off and mines resaturate (flood). "Pre-law" mines that were operated and closed prior to the Clean Water Act (33 U.S.C. § 1251 et seq., 1972) commonly fully flood over time and discharge to the surface. Water levels in "post-law" mines are often controlled below discharge elevations by pumping. 


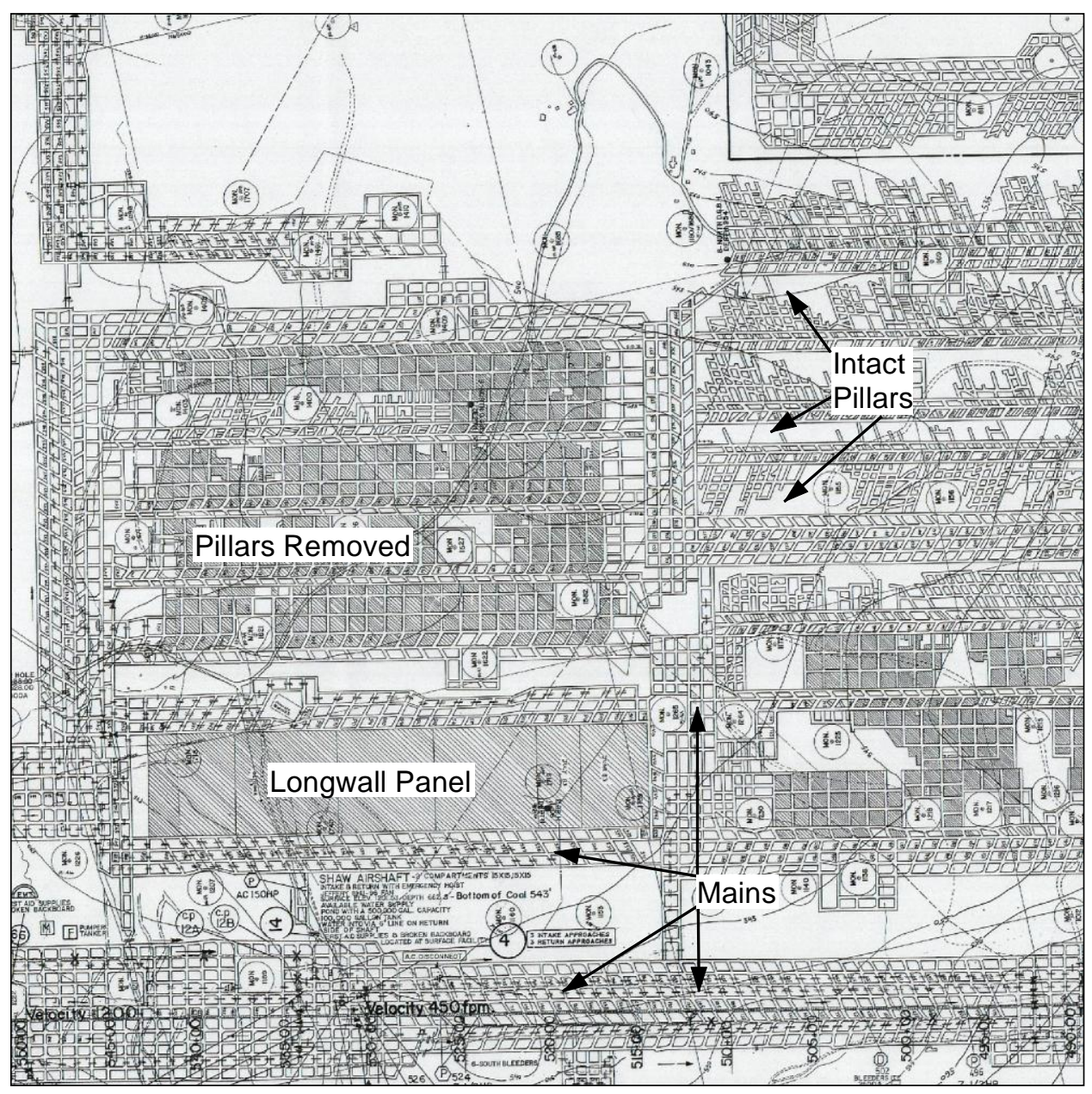

Figure 2.3. Plan view of typical mine showing spatial variation in mining method. 


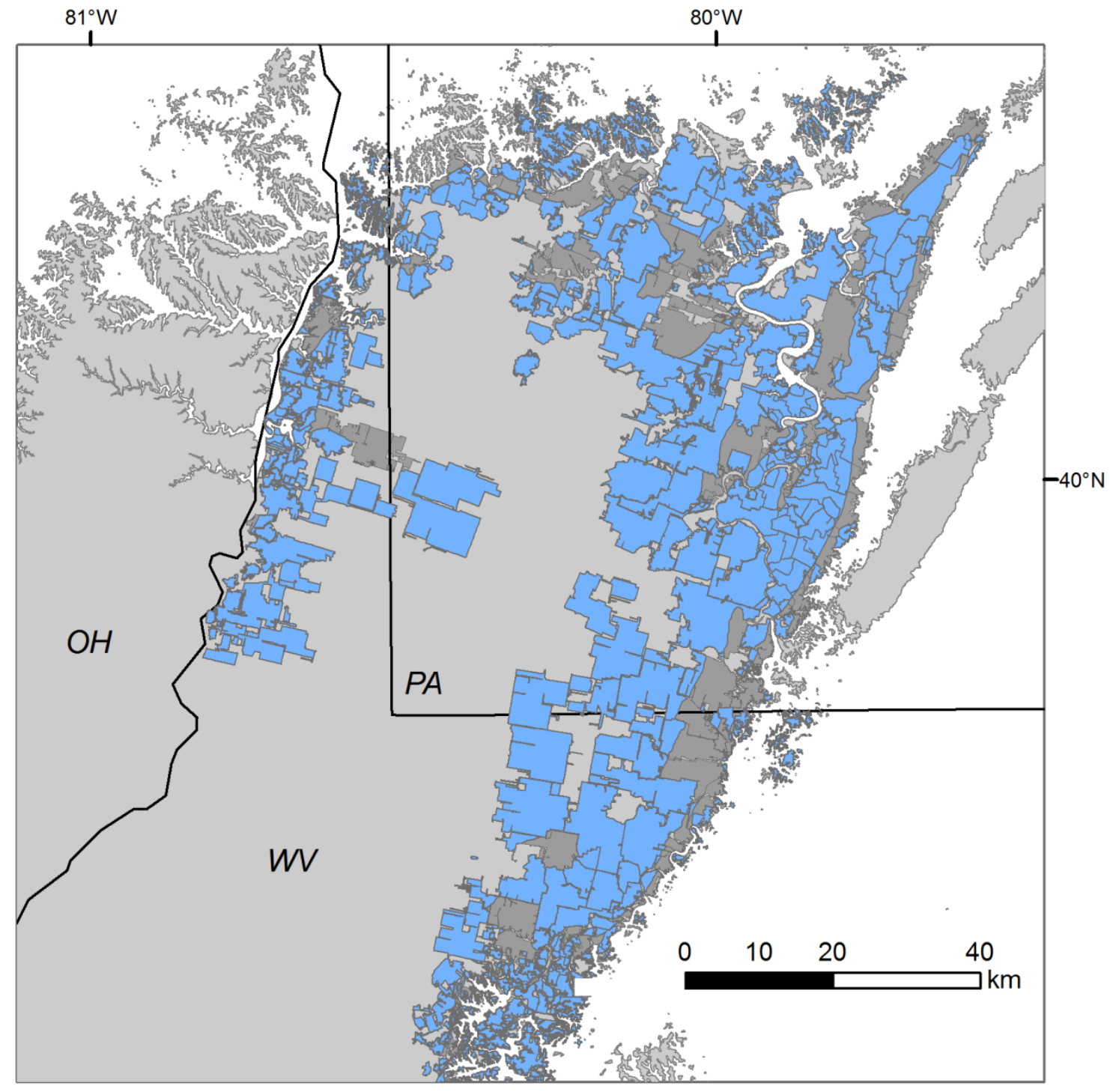

Figure 2.4. Approximate extent of flooding as of 2015 (blue) in Pittsburgh seam mines (dark grey). 


\subsection{Previous Research}

\subsubsection{Mine Subsidence}

Rock movement caused by mining, such as subsidence or roof collapse, is influenced by mining methods, mine geometry, overburden thickness, geology, and time (Singh and Kendorski, 1981; Booth, 1986; Palchik, 2003). Kendorski (1993) presents a model for subsidence with overburden divided into five zones, each defined by the nature and extent of movement (Figure 2.5). In areas of the mine with insufficient roof support, overburden will collapse into the mine void creating a caved zone (Figure 2.5). Material in the caved zone is completely disrupted creating a jumbled pile that builds until it supports overlying materials. The height of the caved zone extends from 6 to $10 t$ above the mine floor; where $t$ is the thickness of the extracted coal bed. Above the caved zone, the fractured zone extends to a height of $24 \mathrm{t}$ to $30 \mathrm{t}$ above the caved zone and contains preexisting vertical fractures that open as unsupported overburden settles onto material in the caved zone (Figure 2.5). Opening of fractures within this zone leads to increased vertical transmissivity (Singh and Kendorski, 1981; Palchik, 2003). Material above the fractured zone tends to separate along bedding planes and settle toward the mine, but is otherwise undisrupted. Bedding separation leads to increased storativity within the dilated zone, which can vary in thickness from 30t to 100t (Figure 2.5). Above the dilated zone, the constrained zone bends as a unit toward the mine, with no significant change in hydraulic properties (Figure 2.5). Subsidence over the mine commonly causes fractures to open at the surface to depths of approximately $15 \mathrm{~m}$, forming the surface fracture zone (Figure 2.5). 


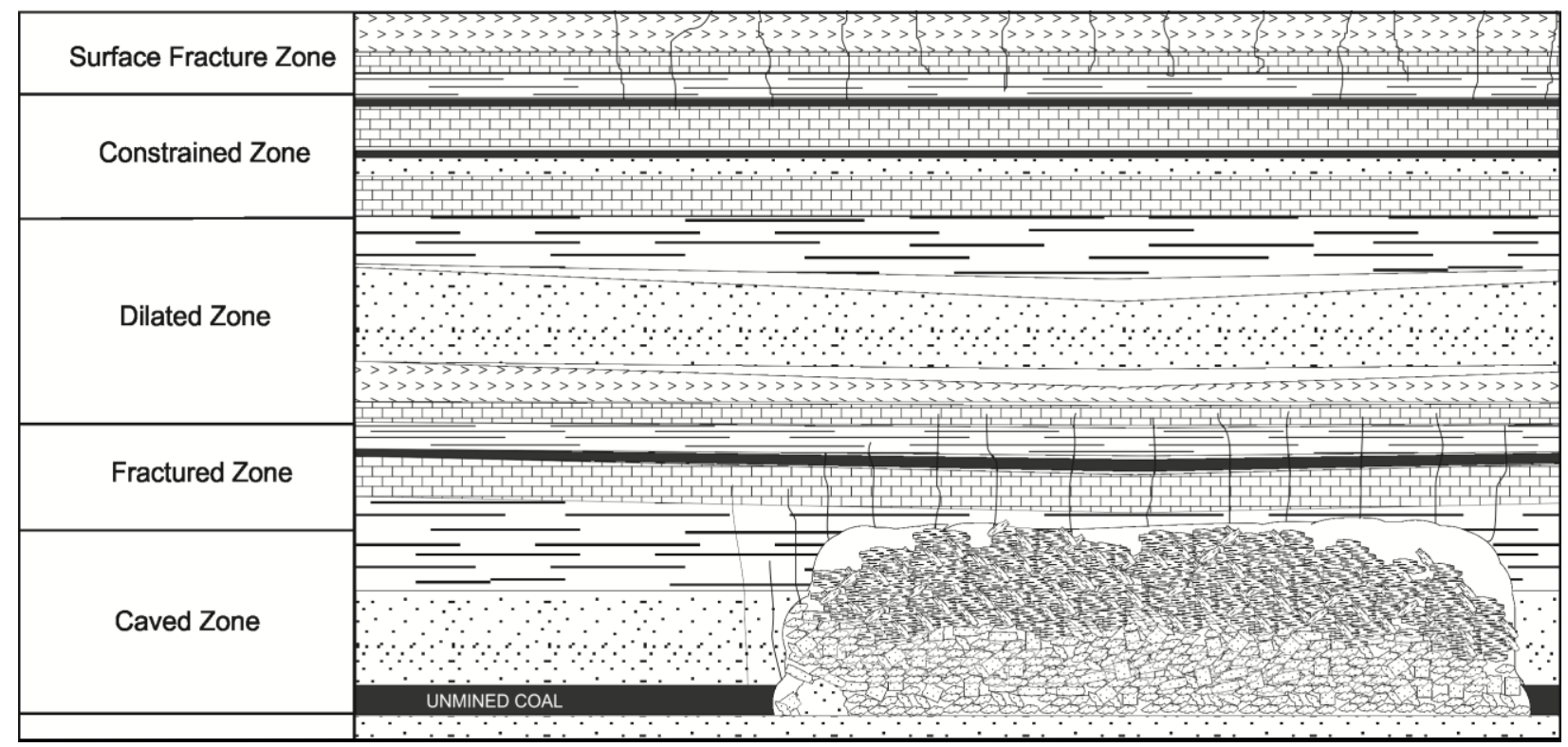

Figure 2.5. Post-mining overburden subsidence zones (after Kendorski, 1993). Not to scale. 


\subsubsection{Mine Flooding/Mine Hydrogeology}

Underground mining requires groundwater removal throughout the operational period of the mine. Once mining is complete, pumps are turned off and groundwater inflow converges in low areas forming "pools." As flooding progresses, the surface levels of isolated pools rise and eventually coalesce into larger pools, and ultimately a single pool (Burke and Younger, 2000). Mine flooding is complete and pools levels are reequilibrated when mine water spills to the surface, leaks to an adjacent mine, or is controlled by pumping (Younger and Adams, 1999). Common spill points are entries (either slope, shaft, or drift) as well as crosscuts between adjacent mines (Younger and Adams, 1999). Reequilibrated mine-pool elevations are expected to approach pre-mining groundwater-level conditions (Matetic et al., 1995) with seasonal variation (Pigati and Lopez, 1999; Light, 2001). Differences between pool-surface elevations in adjacent mines is an indicator of intact intra-mine coal barriers (McCoy et al., 2006).

The rate and duration of flooding is dependent upon factors that include mine aquifer pore volume and inflow rates (Younger and Adams, 1999). Mining significantly increases porosity relative to native coal (Singh and Kendorksi, 1981; Hobba, 1991), while subsidence significantly increases the hydraulic conductivity of overburden materials as well as the depth and circulation rate of groundwater (Stoner et al., 1987; Palchik, 2003). Initial inflow rates are relatively high due to the large head difference between the mine (sink) aquifer and overlying and adjacent (source) aquifers, but decrease exponentially as flooding progresses due to reduction in this head difference (Whitworth, 2002). Inflow rates vary seasonally due to evapotranspiration (Booth, 1986) and are greatest in areas of thin overburden where the surface fracture and facture zones intersect (Winters and Capo, 2004; McDonough et. al., 2005). 
The flow path and residence time of inflow is determined in part by the flooding stage within the mine. During early flooding, groundwater accumulates in low areas forming ponds, which later coalesce into a main pool. After development of a main pool and saturation along inter-mine coal barriers, water may be lost to or gained from adjacent mines via barrier leakage. Barrier seepage rates depend upon several factors including barrier thickness and hydraulic conductivity (McCoy et al., 2006). Groundwater that is not lost to barrier leakage fills the mine beginning with pore space within the rooms, mains, and gob areas in the caved zone and typically will discharge to the surface if left unmanaged.

\subsection{Conceptual Model of Coal-mine Aquifers}

The subsidence model presented by Kendorski (1993; Figure 2.5) provides a basis for a 4-layer model of coal mine aquifers (Figure 2.6). The conceptual model assumes that the Pittsburgh coal is uniformly two m thick. Layer 1 represents a combination of mine voids and caved zone and is expected to be a relatively high hydraulic conductivity mixture of rooms, mains, and rubblized areas (Figure 2.6). Unconfined groundwater storage in Layer 1 is contained in pores within rooms, mains, and caved areas. Layer 2 encompasses the fractured zone and is characterized by relatively high vertical hydraulic conductivity and low horizontal hydraulic conductivity (Figure 2.6). The dilated zone comprises Layer 3 and acts as an aquitard to vertical flow, yet horizontal hydraulic conductivity in this zone is high due to bedding plane separation (Figure 2.6). Layer 4 is uppermost, contains the surface fracture zone, and extends to depths that vary with overburden thickness (Figure 2.6). Not all of the layers will be present in all areas of the mine. In areas where overburden is < $30 \mathrm{~m}$ thick, only Layers 1 and 4 are present and the surface fracture zone intersects the caved zone making these the most productive recharge areas (Figures 1.1 and 2.6). 


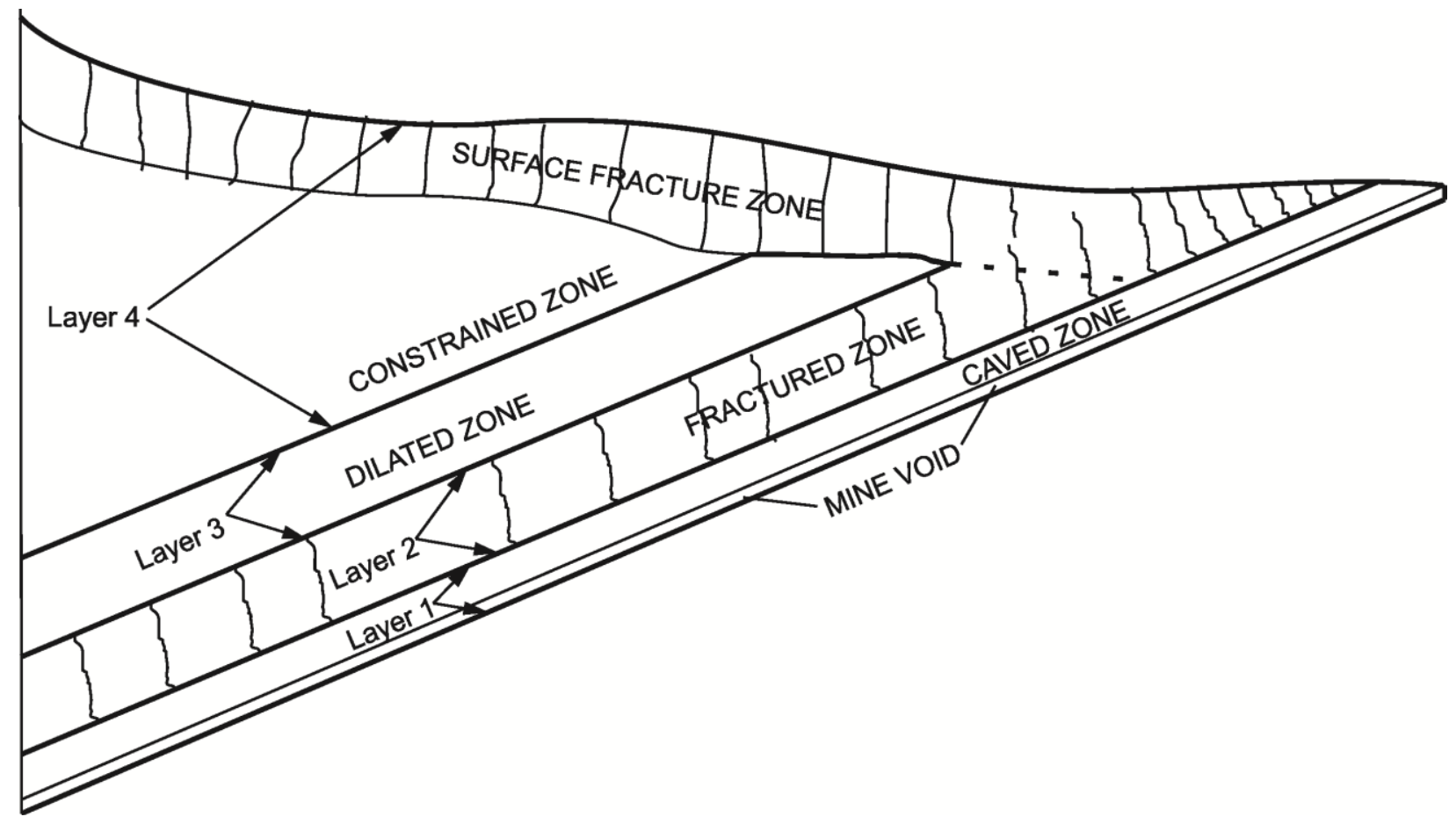

Figure 2.6. Cross section of coal-mine aquifer model (zones from Kendorski, 1993). 
Layer 2 will be present in areas where the overburden thickness exceeds $30 \mathrm{~m}$. Recharge will also be high in these areas, but will decrease with increasing overburden thickness due to reductions in vertical hydraulic conductivity (Palchik,2003). Layer 4 will be present in areas with more than $90 \mathrm{~m}$ of overburden. Vertical groundwater flow will be increasingly retarded by this layer as its thickness increases.

Groundwater moves predominantly vertically downward through the upper layers, but horizontally through Layer 1 (Figures 1.1 and 2.6). During the early stages of flooding, flow in Layer 1 is toward low elevation areas (Figure 2.7), but this pattern changes with continued flooding. In the middle and late stages of flooding, flow may be toward leaky barriers between adjacent mines, while the post-reequilibration flow direction will be predominantly toward groundwater sinks such as pumps, leaky barriers, surface discharges, and artesian storage (Figure 2.8).

A narrow phreatic surface between the roof and floor of the mine forms coincident with development of the mine pool and migrates updip as flooding continues (Figure 1.1). The phreatic surface will mainly be located with Layer 1 . As the pool migrates and phreatic surface rises into Layer 2, the aquifer begins to transition from unconfined to confined conditions resulting in "semi-confined" conditions within Layer 2 that are due to reductions in porosity and vertical hydraulic conductivity that occur with increasing height above the collapsed zone (Figure 1.1). As the potentiometric surface of the mine pool rises above the bottom elevation of Layer 3, the deep portion of the aquifer becomes fully confined (Figure 1.1). 


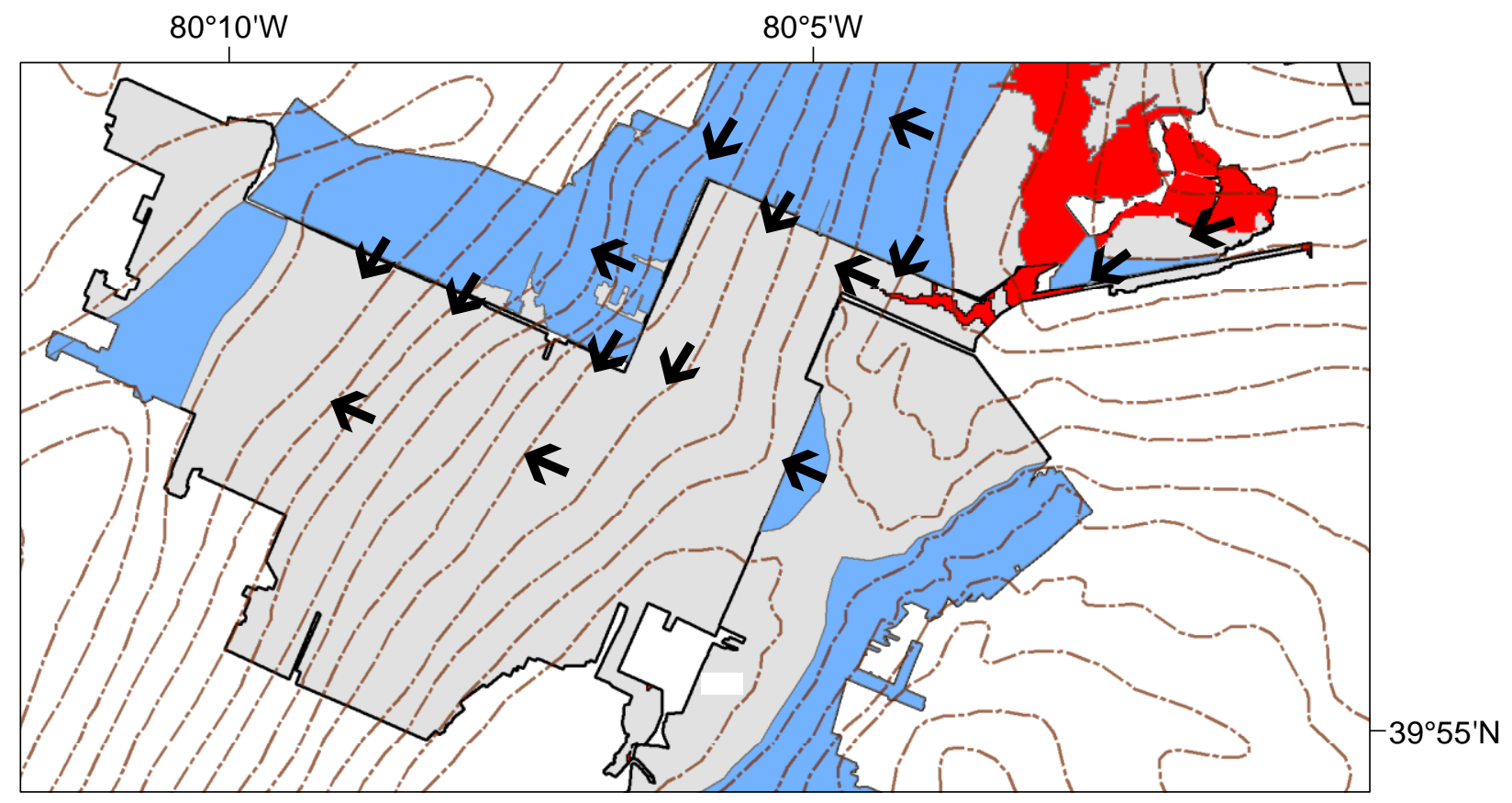

Figure 2.7. Plan view of adjacent mines showing inferred groundwater flow (arrows) from principle recharge areas (red) and through leaky barriers. 


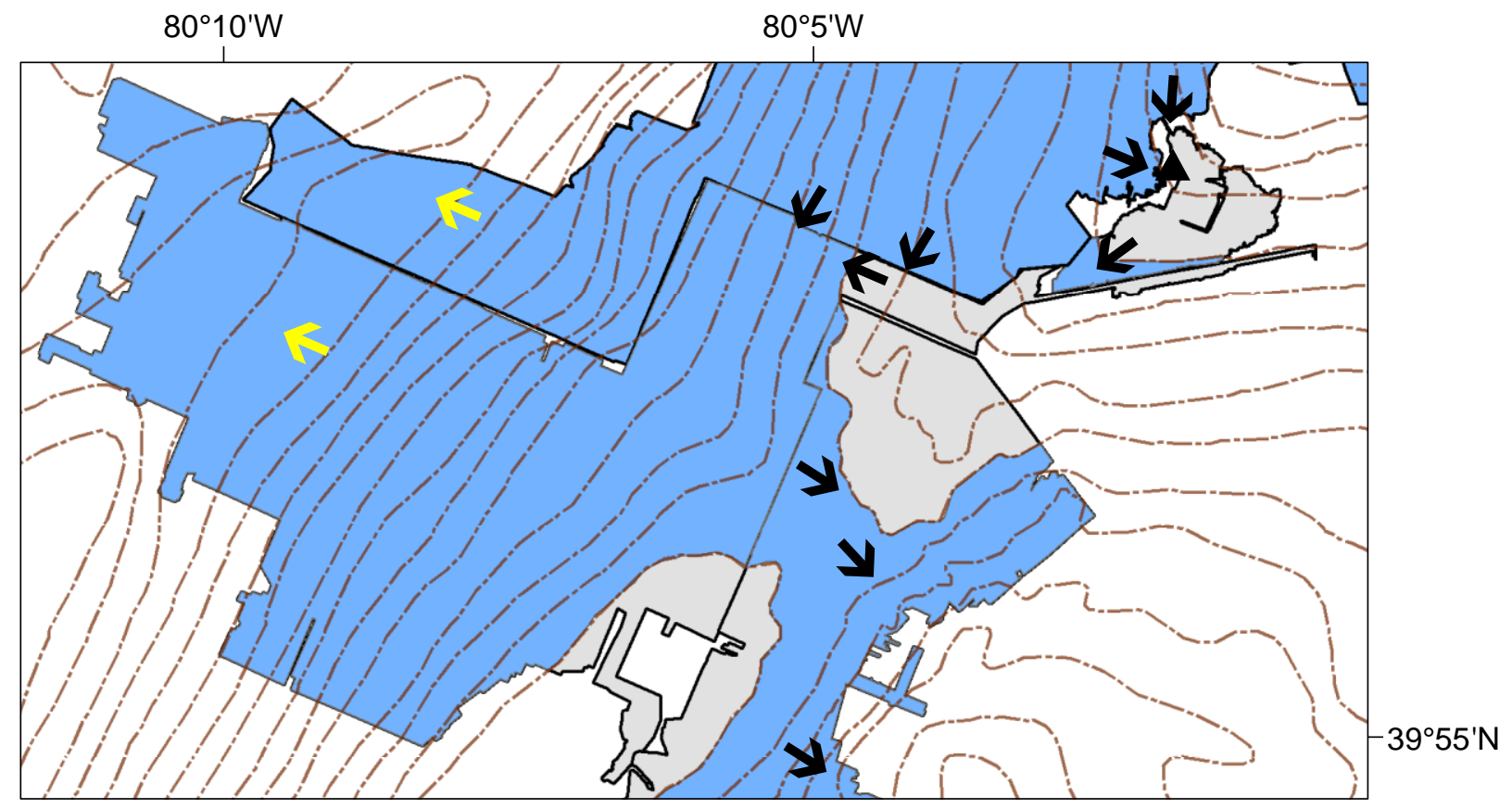

Figure 2.8. Plan view of late-stage mine flooding indicating groundwater flow toward sink that may include leaky barriers, treatment plants (triangle), and additions to confined storage (yellow arrows). 


\subsection{Data Sets}

Data for this project include file data collected from various sources and mine pool elevations calculated from field measurements. Mine maps and permit files of the Pennsylvania Department of Environmental Protection (PADEP) contain information regarding mine operations, pool elevations, pumping records, and surface discharges. Precipitation data from five National Climatic Data Center (NCDC) weather stations (Charleroi, USC00361377; Donora, USC00362190; Gray's Landing, USC00363451; Greensboro Lock and Dam, USC00363503; and Waynesburg USC00369367; Figure 2.9), were averaged to produce a 35-year precipitation history for the study area (Figure 2.10). Average daily discharge rates for the Monongahela River near Masontown, PA (Station 03072655; Figure 2.9) during 2013 and 2014 were obtained from the USGS. 1998-2005 mine pool elevations were determined by Donovan et al. (2003).

Beginning in May 2005, depth-to-water measurements and mine fluid pressures collected in eight monitoring wells completed in seven Pittsburgh bed mines were used to calculate mine pool elevations for these mines (Figure 2.9). Fluid pressures were recorded using transducers installed in the wells, while depth-to-water measurements, used for quality control of the transducer measurements, were made during site visits. Early fluid pressures were recorded using vented transducers, which measure fluid pressure. Later, the vented units were replaced with non-vented ones that measure absolute pressure (fluid plus atmospheric pressures). Simultaneously, transducers were deployed to record barometric pressure at two locations (Figure 2.9). Barometric pressure was subtracted from absolute pressure to produce fluid pressure. Mine pool elevations were calculated by adding fluid pressures to transducer elevations. 


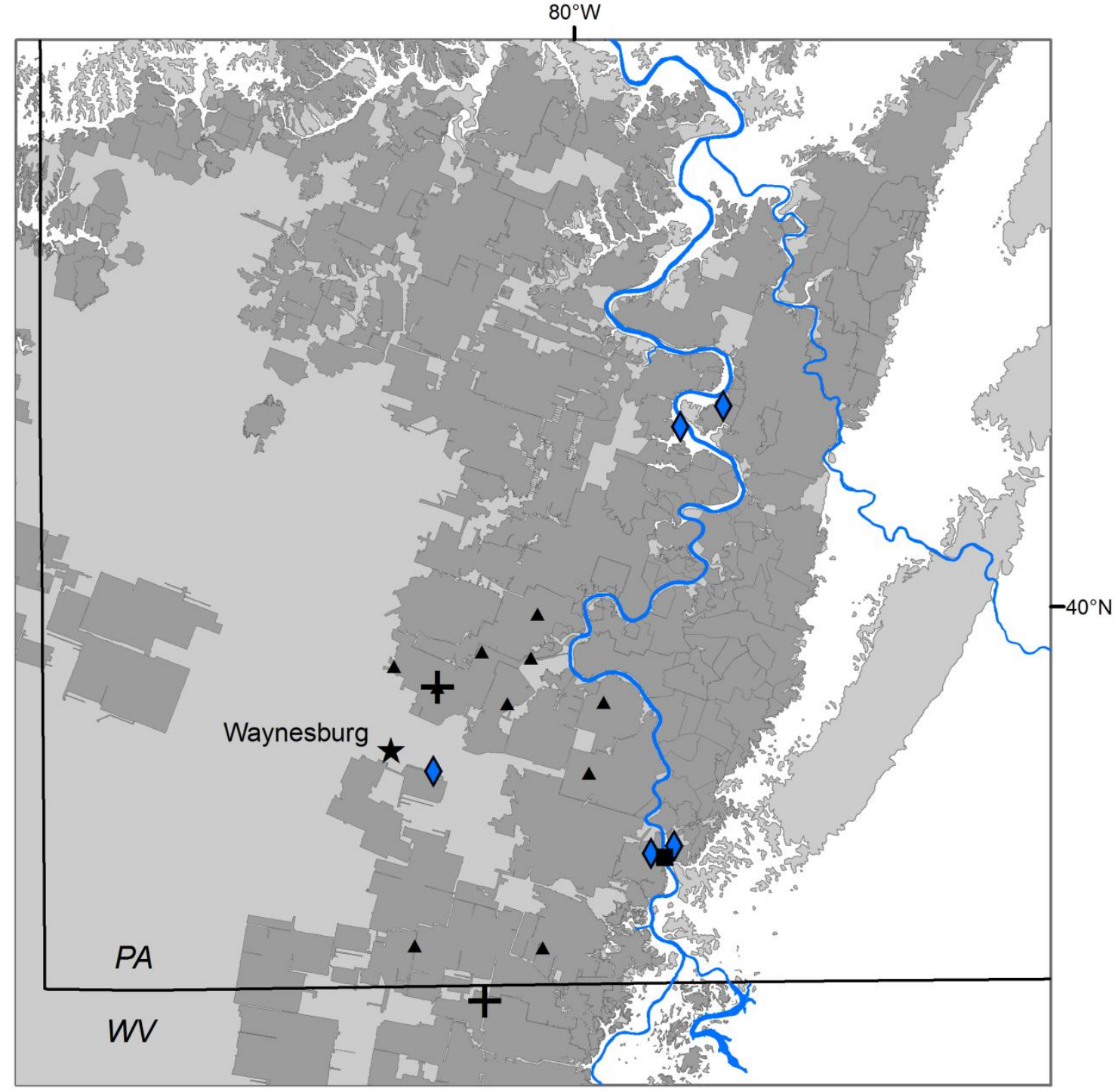

Figure 2.9. Study area showing monitoring wells (triangles), barometric pressure stations (crosses), Precipitation stations (diamonds), and USGS stream gage (square). 


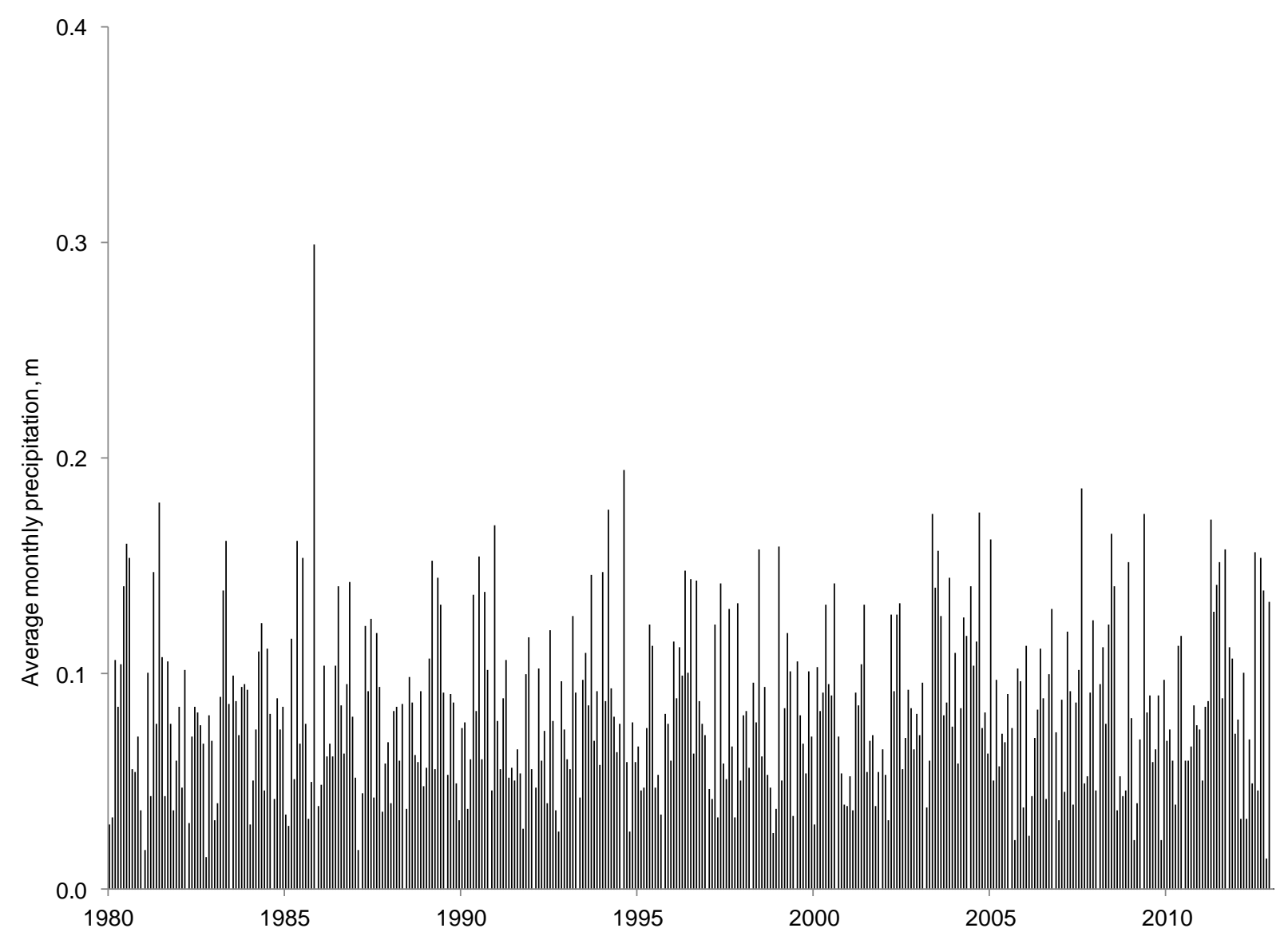

Figure 2.10. Monthly precipitation averaged from five stations. See figure 2.9 for station locations. 


\section{MINE-WATER FLOW BETWEEN CONTIGUOUS FLOODED UNDERGROUND COAL MINES WITH HYDRAULICALLY- COMPROMISED BARRIERS}

\section{Chapter Abstract}

Groundwater flow entering closed contiguous underground coal mines may be strongly influenced by leakage across inter-mine barriers. This study examines a complex of multiple closed and flooded mines that developed into a nearly steady-state groundwater flow system within 10 to 50 years after closure. Field water-level observations, mine geometry, barrier hydraulic conductivity, recharge rates, and late-stage storage gains were parameterized to match known pumping rates and develop a fluid mass balance. Vertical infiltration (recharge and leakage) estimates were developed using a depth-dependent model based on the assumption that most vertical infiltration is focused in areas with $<75$ meters of overburden. A MODFLOW simulation of the nearly steady-state flow conditions was calibrated to hydraulic heads in observation wells and to known pumping rates by varying barrier hydraulic conductivity. The calibrated model suggests significant head-driven leakage between adjacent mines, both horizontally through coal barriers and vertically through interburden into a shallower mine in an overlying bed. Calibrated barrier hydraulic conductivities were significantly greater than literature values for other mines at similar depths in the region. This suggests that some barriers may be hydraulically compromised by un-mapped entries, horizontal boreholes, or similar features that act as drains between mines. These model results suggest that post-mining interannual equilibrium conditions are amenable to quantitative description using mine maps, sparse 
observation-well data, accurately-estimated pumping rates, and depth-dependent vertical infiltration estimates. Results are applicable to planning for post-flooding water control schemes, although hydraulic testing may be required to verify model results.

\subsection{Introduction}

Underground mines can be classified into two groups: above drainage and below drainage. Above drainage mines can be further divided according to the direction of mining: up-dip or down-dip. Up-dip mines are "free-draining." Infiltration that reaches these mines flows downdip along the mine floor and discharges at portals and other connections to the surface, while infiltration that enters down-dip above drainage mines and all below drainage mines flows to the lowest parts of the mine resulting in mine flooding. Both groundwater inflow rates and accurate mine maps are essential for predicting the duration of flooding and subsequent mine-water discharge to the surface. Groundwater-inflow estimation for closed underground coal mines constrains recharge to areas of relatively shallow overburden and neglects leakage to deeper mined areas (Winters and Capo, 2004; McDonough et al., 2005; McCoy et al., 2006). Published recharge rates applied to mines with relatively small areas of thin overburden cover, therefore, are generally minimum estimates of mine inflows. Mine maps and accurate groundwater inflow rates (recharge and leakage) are essential to predict the time required for a mine to flood (Whitworth, 2002; Younger and Adams, 1999). Inflow rates and maps alone, however, often yield inaccurate estimates of flooding times for individual mines that are directly adjacent to, and therefore potentially connected to, other mines. In some cases groundwater-elevation and minepool data for multiple mines show highly similar pool behavior between mines suggesting interconnection. As a result, an improved understanding of the hydrogeological interactions 
between adjacent mines that stems from the development of more realistic mine-inflow models and groundwater-flow models depicting conditions in multiple adjacent mines will help clarify and improve predictions of the mine-flooding process. Such information will benefit postclosure operations by allowing more robust sizing, design, and location of mine-water extraction pumps and treatment plants, as well as the development of plans for mine-water control.

\subsection{Purpose}

The purposes of this research are to improve the understanding of post-flooding hydrogeological interactions between contiguous underground coal mines and to present a method for estimating mine inflow that includes vertical infiltration in areas with relatively thick (>100 m) overburden. The improved understanding stems from a steady-state groundwater-flow model that was conceptualized using mined areas, inter-mine barrier thicknesses, and a water budget that is based on known pumping volumes and estimated mine-water inflows. Inter-mine coal-barrier hydraulic conductivities were calibrated using known groundwater elevations and used to calculate horizontal flow between mines. Mine inflows were determined using a depthdependant vertical infiltration model that is based on published recharge rates and overburden thicknesses. The depth-dependent model offers improved vertical infiltration estimation over earlier methods especially when the depth of mining becomes relatively deep.

\subsection{Background}

Underground mining creates void space, removes support for overburden, and changes stress fields, frequently resulting in subsidence of over-lying strata (Singh and Kendorski, 1981; Booth, 1986). Subsidence features have been categorized into zones that consist primarily of 
collapsed and rubblized roof rock, vertical fractures, bedding-plane separations, and sagging yet otherwise constrained strata (Singh and Kendorski, 1981; Kendorski, 1993). After mine closure, groundwater extraction ceases and voids created by mining and subsidence begin to re-saturate resulting in an anthropogenic aquifer (Adams and Younger, 2001). Flooding in these coal-mine aquifers is marked by the initial development of a phreatic surface or "pool" in the deepest portion of the mine (Donovan and Fletcher, 1999) that with continued flooding migrates up-dip toward shallower mined areas. Flooding ceases when the pool level reaches the elevation of a "spill point" (Younger and Adams, 1999); alternately mine inflows may be balanced by loses to barrier leakage or by groundwater-extraction pumping. Flooding progress tends to follow a decaying exponential curve over time, with flooding rates decreasing as the pool level approaches the elevations of either groundwater sources or spill points (Whitworth, 2002). The duration of flooding varies and is controlled by recharge rates as well as the flooding status of adjacent mines. Shallow mines tend to receive more recharge than deeper ones (Winters and Capo, 2004) and therefore tend to flood more rapidly.

Considerable research has been conducted on the hydrogeology of closed underground coal mines including the chemistry (Banks et al., 1997), volume (Pigati and Lopez, 1999), and seasonality (Pigati and Lopez, 1999; Light, 2001) of mine-water discharges. Others have examined mine aquifer properties such as porosity (Hawkins and Dunn, 2007), specific yield (McCoy, 2002), hydraulic conductivity (Aljoe and Hawkins, 1992), and retention time (Sahu and López, 2009; Winters and Capo, 2004). Flooding histories have been utilized to develop models for prediction of mine flooding (Whitworth, 2002; Younger and Adams 1999). Recharge-rate estimates for flooding and flooded mines vary from "the miner's-rule-of-thumb" (Stoertz et al., 
2001) to calculations that are based on discharge volumes (McDonough et al., 2005; Winters and Capo, 2004), pumping records (Hawkins and Dunn, 2007), and numeric modeling (Williams, et al., 1993; Stoner et al., 1987). Recharge is commonly restricted to areas of relatively shallow overburden (< 18 m, McDonough et al., 2005; and < 75 m Winters and Capo, 2004); while leakage is typically not considered a significant source of groundwater for mine aquifers, although it has been shown to occur and even quantified (McCoy et al., 2006; Leavitt, 1999). Neglecting leakage suggests that deep mines should be "dry" or have limited groundwater inflow, and results in recharge rates that are significantly greater than published values. This would indicate that leakage should have been included in estimations of inflows to deeper mines. For the purposes of this investigation, recharge and leakage will be un-differentiated and referred to as vertical infiltration.

Unconfined storage in coal mines occurs mainly in the area near the "beach" where the phreatic surface intersects the floor of the mine (Hawkins and Dunn, 2007). Its value has been estimated for different extraction methods based on, surface subsidence, coal bed thickness, and the height of roof collapse (McCoy, 2002). It has also been estimated using pumping rates and corresponding changes in hydraulic head (Hawkins and Dunn, 2007). Confined storage, similar to vertical infiltration in relatively deep mined areas, is commonly neglected although it could represent a significant volume of water areas of confined groundwater. Inter-mine coal barrier leakage rates have also been estimated (Hawkins and Dunn, 2007; McCoy et al., 2006). 


\subsection{Study Area}

The study area for this research includes seven Pittsburgh coal mines located within the Pittsburgh basin, Greene County, Pennsylvania (Figures 3.1 and 3.2). The mines operated for various periods, but all closed between 1964 and 2004 and as of spring 2013 were in the final stages of flooding, fully-flooded, or managed by pumping to control mine-pool levels. Both the fully-flooded mines (Crucible and Nemacolin) and the late-stage flooding mines (Pitt Gas and Gateway) contain pools with elevations above the surface of the adjacent Monongahela River (Figures 3.2 and 3.3). Mine water is pumped to water-treatment plants from two locations in the study area (Dilworth and Robena), and also from adjacent mines (Shannopin and Warwick \#2), in order to manage pool levels in those mines. The study area is bordered by other Pittsburghbed mines (Clyde, Humphrey, Shannopin, and Warwick \#2) and is partially overlain by a mine in the Sewickley coal bed (Warwick \#3) (Figure 3.2). There are no known surface discharges within the study area, although groundwater began discharging from an adjacent mine (Clyde, Figure 3.2) during early 2013 after temporary cessation of pumping operations in that mine. The water level in one mine (Mather) is currently unknown, but the mine is believed to be fullyflooded with a pool elevation midway between those in adjacent mines (Gateway and Dilworth).

\subsection{Geologic and Hydrogeologic Setting}

The Pittsburgh coal basin, located within the Appalachian Plateau physiographic province (Fenneman, 1938), is bounded by the outcrop of the Pennsylvanian-age Pittsburgh coal bed in parts of southwestern Pennsylvania, southeastern Ohio, and northern West Virginia (Figure 3.1). The Pittsburgh coal is the basal unit of the Monongahela Group (Figure 3.4), which also contains 


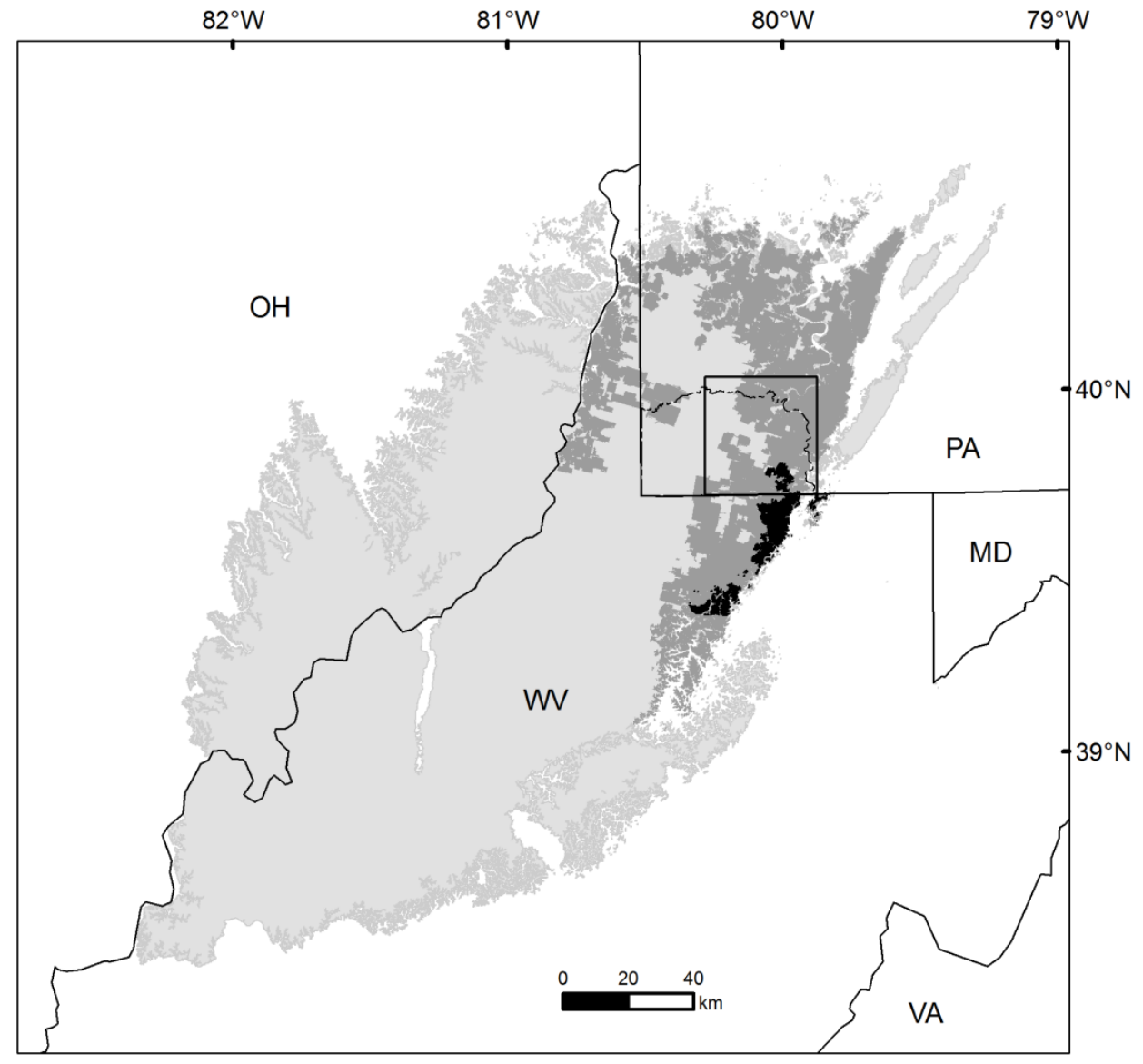

Figure 3.1. Extent of the Pittsburgh coal seam (light shading) with areas of underground mining in the Pittsburgh (medium shading) and Sewickley (dark shading) seams, and Greene County (dashed line). 


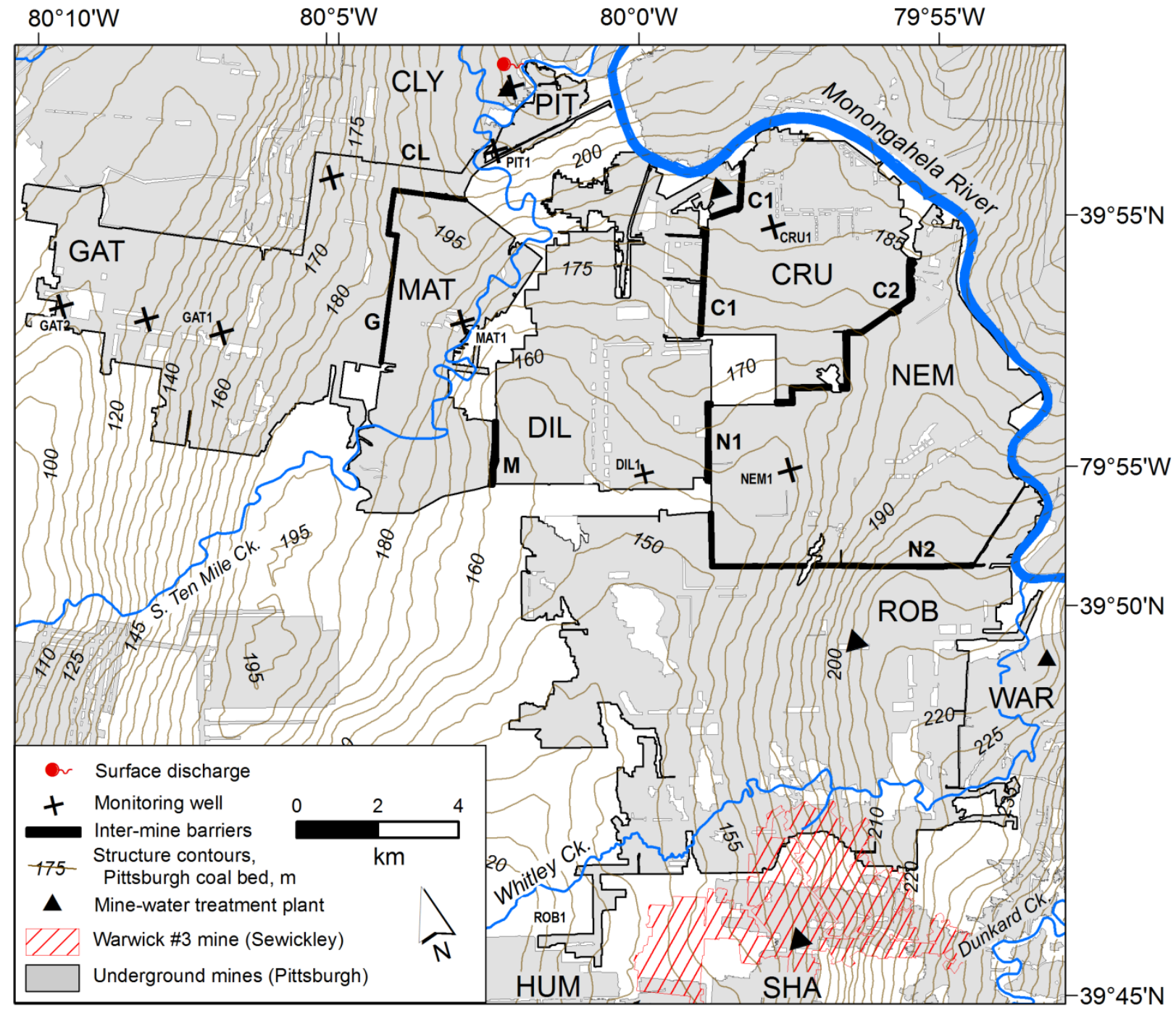

Figure 3.2. Underground Pittsburgh-seam mines in the study area with structure contours of coal bottom (5-meter interval), locations of monitoring wells, inter-mine barriers, mine-water treatment plants, $(\mathrm{CLY}=\mathrm{Clyde} ; \mathrm{CRU}=$ Crucible; $\mathrm{DIL}=$ Dilworth; Gateway $=$ GAT; HUM $=$ Humphrey; Mather $=$ MAT; NEM = Nemacolin; PIT = Pitt Gas; ROB = Robena; SHA = Shannopin; and WAR = Warwick \#2). 


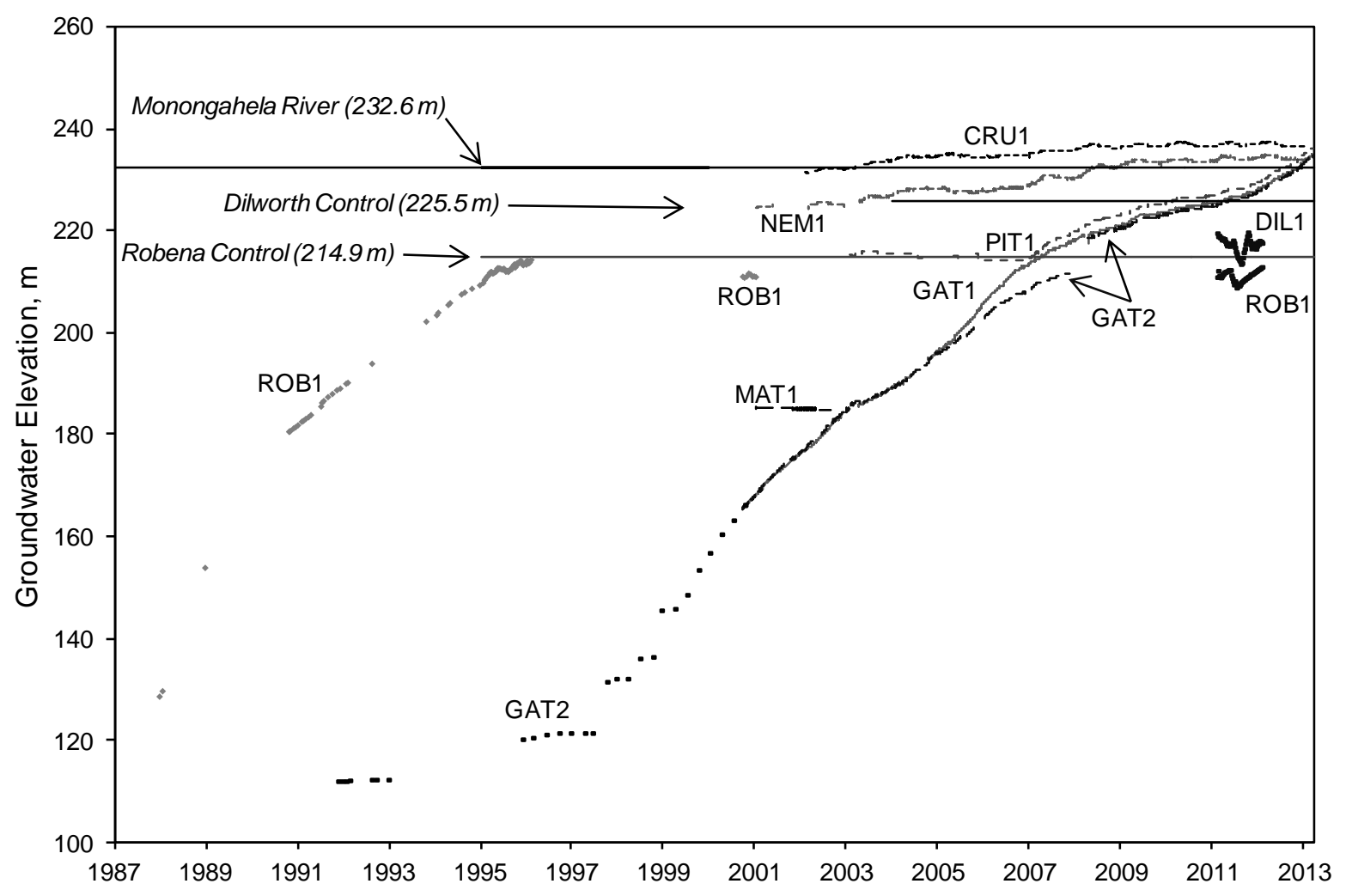

Figure 3.3. Groundwater elevations indicate fairly uniform pool levels in mines with multiple observation wells (CRU1 = Crucible; DIL1 = Dilworth; GAT1 and GAT2 = Gateway; NEM1 = Nemacolin; PIT1 = Pitt Gas; and ROB1 = Robena). The average surface elevation in the Monongahela River (Maxwell Pool) and minewater-treatment plant control levels are indicated by arrows. 


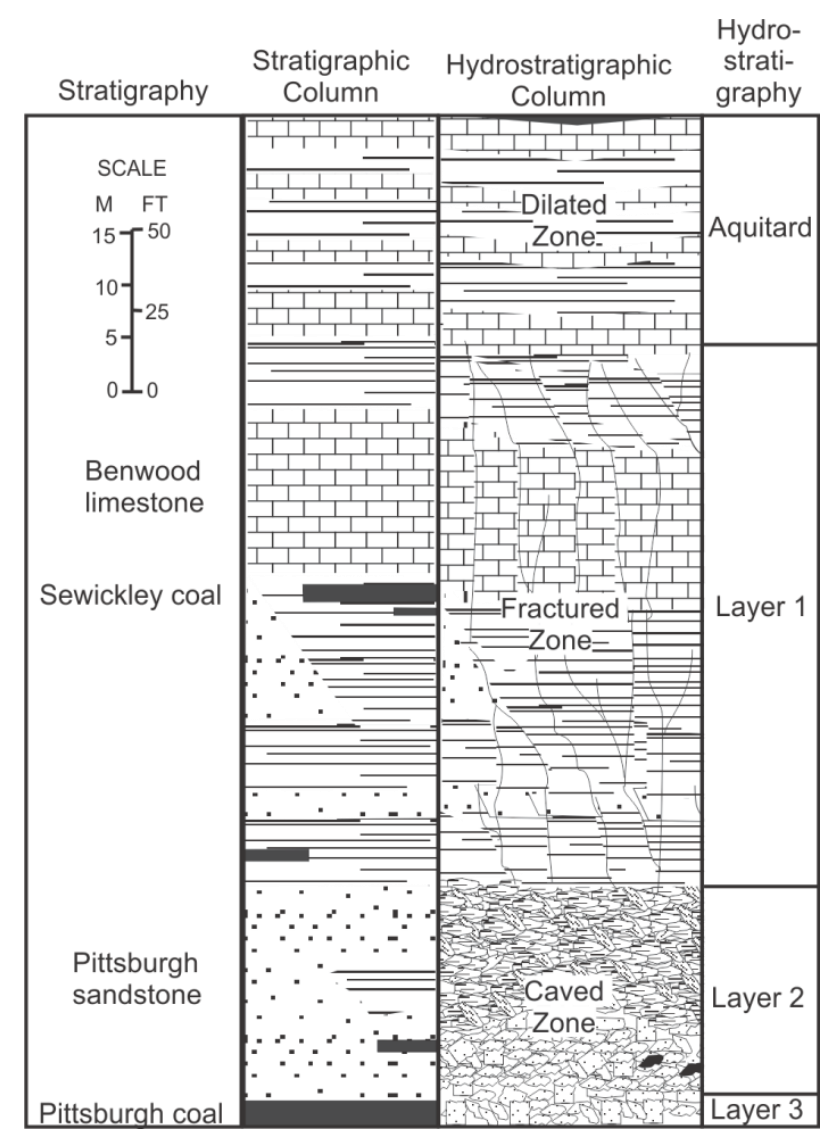

Figure 3.4. Generalized hydrostratigraphy of the Pittsburgh Formation Upper Pennsylvanian Monongahela Group (after Edmunds et al., 1997). Scale is approximate. 
the Uniontown Formation. The coal bed varies in thickness but averages 2.0 meters with minor variance in the study area. The Pittsburgh Formation consists of alternating layers of sandstone, limestone, dolomitic limestone, calcareous mudstones, shale, siltstone, and coal (Edmunds et al., 1999). The Sewickley coal, which lies stratigraphically above the Pittsburgh coal by approximately 30 meters, is also mined in the basin (Figures 3.1 and 3.4), but is neither as thick nor as extensive as the Pittsburgh coal (Hennen and Reger, 1913). The Dunkard Group overlies the Monongahela Group and varies in thickness up to 365 meters (Edmunds et al., 1999). Structural dip of all these strata is typically less than five degrees (Beardsley, et al., 1999).

Rocks in the Appalachian Plateaus Province tend to have low primary porosity and permeability (Stoner, 1983). Groundwater flow is primarily through networks of stress-relief fractures and bedding-plane separations, which occur along valley walls and parallel to valley bottoms (Wyrick and Borchers, 1981; Kipp and Dinger, 1987). Hydraulic conductivity and storativity tend to decrease with depth (Stoner, 1983) and only a small portion of natural groundwater flow extends to depths greater than 50 meters (Stoner et al., 1987). The removal of coal by underground mining and consequent subsidence-induced re-distribution of overburden has considerable impacts on the un-disturbed groundwater flow regime (Stoner, 1983; Booth, 1986). Underground coal mining can also impact surface water by reducing runoff and increasing baseflow (Stoner, 1987). Mining induced subsidence tends to create large voids and rubble zones with hydraulic conductivity greatly increased (Singh and Kendorski, 1981; Kendorski, 1993; Aljoe and Hawkins, 1992) over native coal and overburden (Hobba, 1991). Above rubblized areas, vertical hydraulic conductivity is similarly increased, but this effect decreases with increasing height above the rubble (Palchik, 2003). Post-closure flooding yields coal-mine 
aquifers (Younger and Adams, 1999), which tend to be locally heterogeneous with preferential flow paths (Aljoe and Hawkins, 1992), due to overburden subsidence, coal pillar geometry, and spatial distribution of highly-transmissive main entries (Figure 3.5). Yet on a mine-wide scale, water levels in different locations within flooded un-pumped mines are often fairly uniform (Aljoe and Hawkins, 1992; Figure 3.3).

Coal-mine aquifers and overlying units can be hydrostratigraphically characterized using overburden subsidence zones (Kendorski, 1993; Figure 3.4). The caved zone contains jumbled overburden collapsed into the mine to heights of 6 to $10 t$, where $t$ is the thickness of the coal bed, while strata in the overlying fractured zone contain vertical fractures and bedding plane separations extending to heights of 24 to $30 t$ above the mine floor. The dilated zone shows bedding-plane separations, increased porosity, and horizontal transmissivity, yet due to the absence of through-going fractures, it acts as the principal aquitard between overlying strata and the fractured and caved zones below. If overburden is sufficiently thick, a constrained zone consisting of gently sagging strata may also be present. The surface fracture zone contains extended and enlarged pre-existing fractures from the ground surface to 15-meters depth. These subsidence zones were developed to describe overburden re-distribution over longwall panels, but similar re-distribution is likely to occur in areas of room-and-pillar mining especially where pillars are fully extracted (Peng, 1986). The distribution of subsided materials and overburden thickness has implications for mine-aquifer water budgets including recharge and leakage. In relatively shallow areas $(<75 \mathrm{~m}$; e.g. Winters and Capo, 2004) where the surface fracture and fractured zones intersect, recharge rates will be highest, while in areas containing thicker 


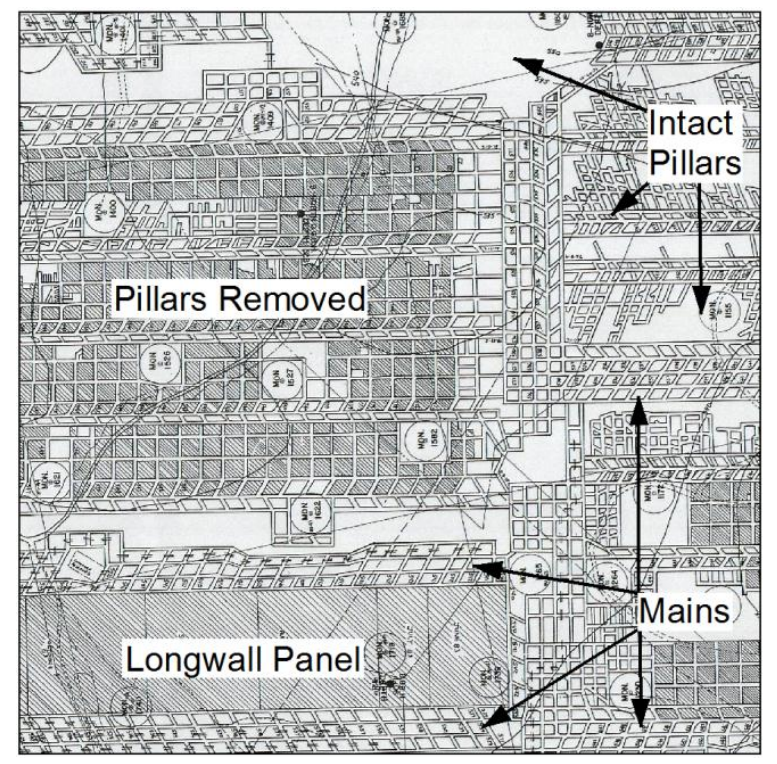

Figure 3.5. Plan view of typical mine map showing variation in mining methods, main entries, and un-mined coal (pillars). 
overburden aquifer inflow will occur as leakage through the dilated zone with relatively low rates. Groundwater movement through overburden is inferred to be predominantly downward into mine voids and collapsed overburden in the caved zone, which are much higher in hydraulic conductivity relative to un-mined coal and rocks. Inter-mine groundwater flow occurs horizontally through coal barriers separating mines (e.g. McCoy et al, 2006; Hawkins and Dunn, 2007) although vertical flow between mines may occur where over- or underlying beds have been mined (Miller, 2000). Flow between mines follows pressure gradients toward discharge locations. For the purposes of this study, recharge and leakage are undifferentiated and referred to as vertical infiltration.

Hydraulic conductivity $(\mathrm{K})$ within coal-mine aquifers is related to the degree of overburden alteration and subsidence and is significantly increased over $\mathrm{K}$ within native coal (Harlow and Lecain, 1993). Within the caved zone, $\mathrm{K}$ in un-collapsed rooms and mains can be very high, while in "gob: (collapsed) areas, collapsed overburden may reduce K values. Shale and other thinly-layered rocks tend to collapse in small pieces, resulting in poorly connected void space, while sandstone and similarly-massive rocks tend to collapse in large blocks leaving significant void space (Palchik, 2002). Strata in the fractured zone will have high vertical hydraulic conductivity $\left(\mathrm{K}_{\mathrm{V}}\right)$ relative to horizontal hydraulic conductivity $\left(\mathrm{K}_{\mathrm{H}}\right)$ (Palchik, 2002), yet the number and size of vertical fractures decreases with increasing distance above the mine void resulting in a similar reduction in $\mathrm{K}_{\mathrm{V}}$ (Palchik, 2003). 


\subsection{Methodology}

\subsubsection{Groundwater-head Data}

Groundwater elevations were calculated for six monitoring wells (Figure 3.2) using depth-towater measurements and pressure transducers. Between September 2000 and November 2005, pressure measurements were made using vented transducers, while after November 2005 measurements were recorded primarily with sealed transducers and corrected using barometricpressure data collected within the study area. Pressures were recorded hourly then converted to average daily water levels using a database. Three of the monitoring wells are previously existing rock-dust boreholes (GAT1, GAT2, and NEM1; Figure 3.2), while the other three wells (CRU1, PIT1, and MAT1; Figure 3.2) were all drilled for the purpose of monitoring mine pool elevations. Historical (pre-September 2000) groundwater-elevations for the pools within Gateway and Robena (GAT1 and ROB1, respectively; Figure 3.2) are from unpublished file data. While, limited recent groundwater elevations for the pumped mines, Dilworth and Robena (DIL1 and ROB1, respectively; Figure 3.2) were provided by treatment-plant operators.

\subsubsection{Geospatial Analysis}

Mine outlines and areas, inter-mine coal-barrier dimensions, and overburden isopach for the study area were mapped using a geographic information system (GIS). Pittsburgh-coal-bed mine maps were obtained from the Pennsylvania Department of Environmental Protection (PADEP), digitized, and geo-rectified using mining features depicted on the maps and located in the field using a global positioning system (GPS). Inter-mine barrier segments were measured and their areas and lengths used to estimate average width. All barriers in the study are assumed to be 
two-meters high, the approximate thickness of the Pittsburgh coal in this area (Edmunds et al., 1999). Pittsburgh coal-bed structure was developed using kriged base-of-coal elevations from mine maps to create a grid. This coal-bed structure grid was subtracted from the 10 -meter Digital Elevation Model (DEM) to create an overburden isopach. Because vertical infiltration rates are dependent upon overburden thickness, the latter is a factor in estimating the volume of groundwater that reaches the mine aquifer.

\subsubsection{Fluid Mass Balance}

A water budget or fluid mass balance (FMB) for mines $i$ in the study area was developed to improve understanding of the flow regime. The FMB includes vertical infiltration (VI), extraction pumping $(\mathrm{P})$, storage changes $(\Delta \mathrm{S})$, surface discharge $(\mathrm{Q})$, and barrier leakage $\left(\mathrm{L}_{\mathrm{B}}\right)$ :

$$
\sum_{\mathrm{i}=0}^{\mathrm{n}}\left(\mathrm{VI}_{\mathrm{i}}+\mathrm{L}_{\mathrm{Bi}}+\mathrm{P}_{\mathrm{i}}+\Delta \mathrm{S}_{\mathrm{i}}-\mathrm{Q}_{\mathrm{i}}\right)=0
$$

Vertical infiltration is the primary source of groundwater, while extraction pumping, surface discharge, and addition to storage are all sinks. Barrier leakage may be a source or sink depending upon whether flow is into or out of the study area. In order to estimate mine inflow within the relatively deep mines of the study area, a depth-dependent vertical infiltration model was developed using published recharge rates for mines in the Pittsburgh coal (Table 3.1). The model uses a constant rate equal to the miner's rule of thumb $(0.67 \mathrm{~mm} /$ day $)$ of Stoertz et al. (2001) for depths from 0 to $30 \mathrm{~m}$ and an exponentially declining rate for depths below $30 \mathrm{~m}$ :

$$
\begin{array}{r}
\mathrm{VI}_{(\mathrm{d})}=\mathrm{VI}_{(0)}\left(\mathrm{d} \leq \mathrm{d}_{1}\right) \\
\mathrm{VI}_{(\mathrm{d})}=\varepsilon \mathrm{VI}_{(0)} \mathrm{e}^{-\lambda(\mathrm{d})}\left(\mathrm{d}>\mathrm{d}_{1}\right)
\end{array}
$$


Table 3.1. Vertical infiltration rates for regional coal mines

\begin{tabular}{|c|c|c|c|c|c|c|c|}
\hline Source & Year & Coal $^{*}$ & State & Outcrops & $\begin{array}{l}\text { Average } \\
\text { Depth }(\mathrm{m})\end{array}$ & $\begin{array}{c}V I \\
(\mathrm{~mm} / \mathrm{d})\end{array}$ & Method \\
\hline Hawkins and Dunn & 2007 & LK; LF & PA & Yes & & 0.36 & Pumping Records \\
\hline McDonough et al. & 2005 & $P$ & PA & Yes & $<18$ & 4.65 & Measured Discharge \\
\hline Stoertz et al. & 2001 & MK & $\mathrm{OH}$ & Yes & 15 & 0.67 & Miner's Rule-of-thumb \\
\hline Stoner et al. & 1987 & $P$ & PA & & & 0.45 & Numeric Model \\
\hline Williams et al. & 1993 & $P$ & PA & & & 0.25 & Numeric Model \\
\hline Winters and Capo & 2004 & & & & & & \\
\hline Delmont & & $P$ & PA & Yes & 31 & 0.72 & Measured Discharge \\
\hline Export & & $P$ & PA & Yes & 37 & 0.59 & Measured Discharge \\
\hline Coal Run & & $P$ & PA & Yes & 37 & 0.46 & Measured Discharge \\
\hline Irwin & & $P$ & PA & Yes & 69 & 0.43 & Measured Discharge \\
\hline Guffey & & $P$ & PA & Yes & 85 & 0.76 & Measured Discharge \\
\hline Marchand & & $P$ & PA & Yes & 94 & 0.30 & Measured Discharge \\
\hline Banning & & $P$ & PA & Yes & 96 & 0.32 & Measured Discharge \\
\hline McCoy & 2002 & & & & & & \\
\hline Barrackville & & $P$ & WV & No & 149 & 0.05 & Fluid Mass Balance \\
\hline Clyde & & $P$ & $\mathrm{PA}$ & No & 136 & 0.19 & Fluid Mass Balance \\
\hline Jamison \#9 & & $P$ & WV & No & 207 & 0.03 & Fluid Mass Balance \\
\hline Joanne & & $P$ & WV & No & 169 & 0.03 & Fluid Mass Balance \\
\hline Jordan & & $P$ & WV & Yes & 130 & 0.11 & Fluid Mass Balance \\
\hline Robena & & $P$ & PA & No & 174 & 0.04 & Fluid Mass Balance \\
\hline Shannopin & & $P$ & PA & Yes & 139 & 0.06 & Fluid Mass Balance \\
\hline Wyatt & & $P$ & WV & Yes & 101 & 0.21 & Fluid Mass Balance \\
\hline Overburden $<18 \mathrm{~m}^{\star \star}$ & & $P$ & PA & No & 166 & 725 & DDVIM \\
\hline Overburden $<75 \mathrm{~m}^{* *}$ & & $\mathrm{P}$ & PA & No & 166 & 3.3 & DDVIM \\
\hline
\end{tabular}

${ }^{*} \mathrm{P}=$ Pittsburgh; $\mathrm{LK}=$ Lower Kittaning; $\mathrm{LF}=$ Lower Freeport; MK = Middle Kittanning.

${ }^{*} \mathrm{VI}$ applied only to areas with overburden less than these thicknesses. 
where $\mathrm{VI}_{(\mathrm{d})}$ is the recharge rate at depth d below land surface, $\mathrm{VI}_{(0)}$ is the maximum vertical infiltration rate in shallow aquifers, $\mathrm{d}_{1}$ is the maximum depth at which the surface fracture and fracture zones intersect, $\lambda$ is a location-specific vertical infiltration decline parameter, and $\varepsilon$ is a fit parameter. $\mathrm{VI}_{(\mathrm{o})}(0.67 \mathrm{~mm} /$ day $)$ is similar to the vertical infiltration rate reported for un-mined areas in Greene County, PA (Stoner, 1983), and roughly 40 percent of the average vertical infiltration rate for aquifers in the Monongahela River basin of northern West Virginia (Kozar and Mathes, 2001). The depth-dependent vertical infiltration model was applied to the overburden isopach yielding a vertical infiltration estimate for the study area.

Groundwater is extracted for treatment from two mines within the study area, and there are no known surface discharges. Increases in confined storage within fully-flooded areas of Gateway and Pitt Gas were determined using the daily average change in water-level elevation during 2012 (Figure 3.3) and a confined-storage coefficient estimate of 0.001 . Specific yield for the small unconfined area within Pitt Gas was calculated (McCoy, 2002):

$$
S_{y}=E_{m} b \frac{C_{s}}{\beta}
$$

where $S_{y}$ is specific yield, $E_{m}$ is the coal extraction ratio, $C_{s}$ is the volume of void space remaining after surface subsidence, $b$ is the height of the coal bed, and $\beta$ is the height of caved overburden. Barrier leakage estimates were calculated using head differences between adjacent mines $\Delta \mathrm{h}_{\mathrm{j}}$; barrier heights $\mathrm{b}$; barrier segments $\mathrm{j}$; barrier segment widths $\mathrm{w}_{\mathrm{j}}$ and lengths $\mathrm{X}_{\mathrm{j}}$; and barrier hydraulic conductivity $\mathrm{K}_{\mathrm{B}}$ (similar to McCoy et al., 2006):

$$
\mathrm{L}_{\mathrm{Bi}}=\sum_{\mathrm{j}=0}^{\mathrm{n}}\left(\mathrm{K}_{\mathrm{B}} \mathrm{bX} \mathrm{X}_{\mathrm{j}} \frac{\Delta \mathrm{h}_{\mathrm{j}}}{\mathrm{w}_{\mathrm{j}}}\right)
$$




\subsubsection{Groundwater-flow Model Development}

Groundwater-flow modeling was applied to better understand the interactions between adjacent flooding and flooded coal mines. The goal of the model is to use groundwater-elevation heads for calibration and pumping rates at water-treatment plants to define the water budget. The numeric model depicts near-steady-state conditions in 2012 during which all mines in the study area except two flooding mines had attained post-flooding hydraulic equilibrium. Groundwater elevations within the two exceptions mines(Gateway and Pitt Gas) were within ten meters of anticipated equilibrium elevation. The pumping and water-level data available for Dilworth and Robena are from 2011, yet are thought to be representative of average conditions in those mines as their pool levels are maintained below control elevations and do not vary significantly from year to year, nor do the average annual pumping volumes. The flow model thus depicts average post-flooding groundwater control conditions, but does not account for seasonal or inter-annual variability.

\subsection{Results}

\subsubsection{Groundwater Hydrographs}

Groundwater-elevation hydrographs for the study area are shown in Figure 3.3. The hydrographs for Crucible and Nemacolin indicate approximate equilibrium with intra-annual fluctuations attributed to seasonal variations in vertical infiltration, precipitation, and evapotranspiration rates (Pigati, and Lopez, 1999; Light, 2001), as well as barrier leakage to adjacent mines. That water levels have equilibrated without surface discharge or pumping control indicates that these mines must lose water entirely to barrier leakage. Their relative 
increases in groundwater elevations between 2007 and 2009 were attributed to the effects of post-closure flooding in adjacent Dilworth, decreasing inter-mine head differences and barrier leakage from these two mines into Dilworth. Dilworth mine-pool-level control pumping began during 2008 and resulted in stabilization of the pools in Crucible and Nemacolin. The Robena hydrograph indicates that extraction pumping managing its pool level has made it a groundwater sink for Nemacolin (Figures 3.2 and 3.3). The stable pool elevation within Mather in 2001-02 shows the mine was only partially flooded during that period, and that any inflow from infiltration was lost by barrier leakage to adjacent Gateway and/or Dilworth (Figures 3.2 and 3.3). While water-level data are unavailable, the pool level in Mather is believed to have begun rising when the pool in Gateway reached the elevation of the barrier separating those mines. The flooding rate in Mather most likely increased following the 2004 closure of Dilworth. The pool in Dilworth is currently (2013) maintained by pumping below 225.5 meters (Figure 3.3). A stable pool elevation prevailed in Pitt Gas prior to 2007 and was maintained by cross-barrier horizontal boreholes that were installed to drain Pitt Gas mine water into Gateway. In early 2007, the groundwater level in Gateway reached the elevation of those drains initiating flooding within Pitt Gas. After 2007, Pitt Gas and Gateway flooded in tandem with fluctuations in the flooding rate attributed to variation in seasonally affected vertical infiltration as well as groundwater heads in adjacent mines (Figure 3.3). Late in 2011, the pool elevation in Pitt Gas reached the elevation of its roof, resulting in accelerated flooding as water filled all mine voids and moved upward into low-porosity overburden fractures. In early 2013, the flooding rate continued to increase and water levels in both mines were above the surface elevation of the Monongahela River (Figures 3.2 and 3.3). The potential for surface discharge from either 
Gateway or Pitt Gas at elevations above 233 meters exists, as does the possibility that vertical infiltration to these mines will be entirely offset by barrier leakage to adjacent mines (similar to the case in Crucible and Nemacolin).

\subsubsection{Geospatial Analysis}

Mines in the study range from 2.3 to $80 \mathrm{~km}^{2}$ in area, while overburden thickness varies from less than $10 \mathrm{~m}$ to more than $300 \mathrm{~m}$ averaging $166 \mathrm{~m}$ (Table 3.2). The mines contain relatively little

area with thin overburden. Less than 0.01 percent of the total area contains overburden under 18 $\mathrm{m}$ thick, and overburden is less than $75 \mathrm{~m}$ thick in only 1.5 percent of the study area (Figure 3.6). Pitt Gas, the smallest and shallowest mine, accounts for roughly 1 percent of the total mined area, yet is the only mine with overburden less than $18 \mathrm{~m}$ thick. Inter-mine coal barriers vary in average width from 22 to 80 meters and in length from 1600 to 7600 meters (Figure 3.2 and Table 3.3). The barriers separating Gateway from Mather and Nemacolin from Robena are the longest and narrowest, while the barriers separating Mather from Dilworth and Nemacolin from Dilworth are relatively short and wide (Table 3.3).

\subsubsection{Fluid Mass Balance}

Initial vertical infiltration estimates were made by applying average daily extraction volumes for the pumps in Dilworth and Robena (Table 3.4, Figure 3.2) first to mined areas with overburden less than $18 \mathrm{~m}$ thick (i.e. McDonough et al., 2005), then to mined areas with overburden less than $75 \mathrm{~m}$ thick (i.e. Winters and Capo, 2004). Both estimates resulted in vertical infiltration rates that were considerably greater than those reported in similar studies (Table 3.1) indicating that vertical infiltration to deeper mined areas is a significant portion of the FMB. Published 
Table 3.2. Mine area and overburden distribution statistics

\begin{tabular}{lcccc} 
Mine & Area & \multicolumn{3}{c}{ Overburden thickness $(\mathrm{m})$} \\
& $\left(10^{6} \mathrm{~m}^{2}\right)$ & Min. & Max. & Avg. \\
\hline Pitt Gas & 2.3 & 8.30 & 153 & 85 \\
Crucible & 22.6 & 35.5 & 222 & 133 \\
Nemacolin & 39.6 & 49.8 & 240 & 142 \\
Mather & 19.9 & 77.5 & 265 & 144 \\
Robena & 79.0 & 31.4 & 328 & 175 \\
Dilworth & 34.1 & 36.4 & 283 & 177 \\
Gateway & 41.0 & 31.0 & 309 & 192 \\
All Mines & 238 & 8.30 & 328 & 166 \\
\hline
\end{tabular}




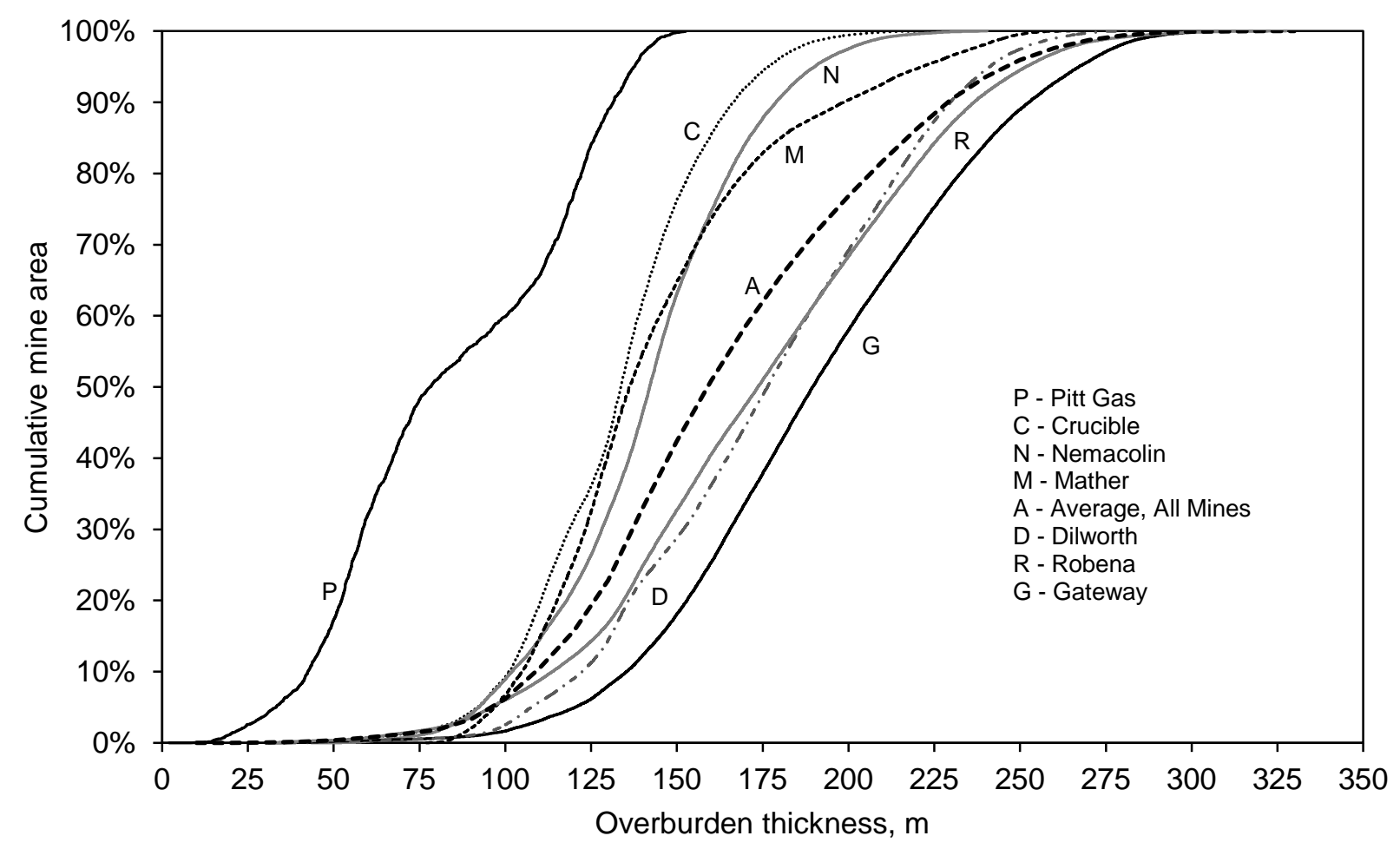

Figure 3.6. Cumulative distribution of mine area versus overburden thickness. See Table 2 for overburden statistics. 
Table 3.3. Measured barrier dimensions (refer to Figure 3.2 for barrier locations)

\begin{tabular}{cccc}
$\begin{array}{c}\text { Barrier } \\
\text { ID }\end{array}$ & Mines & $\begin{array}{c}\text { Total } \\
\text { Length }(\mathrm{m})\end{array}$ & $\begin{array}{c}\text { Average } \\
\text { Width }(\mathrm{m})\end{array}$ \\
\hline C1 & Crucible-Dilworth & 4395 & 60 \\
C2 & Nemacolin & 5920 & 67 \\
G & Gateway-Mather & 6290 & 22 \\
M & Mather-Dilworth & 1600 & 80 \\
N1 & Nemacolin-Dilworth & 2000 & 61 \\
N2 & Nemacolin-Robena & 7570 & 36 \\
\hline
\end{tabular}


Table 3.4. Vertical infiltration, pumping, storage, and leakeage rates

\begin{tabular}{|c|c|c|c|c|}
\hline Mine & & $s$ & VI & $B_{L}$ \\
\hline Crucible & & & 2981 & \\
\hline C1 & & & & 1774 \\
\hline $\mathrm{C} 2$ & & & & 1207 \\
\hline Dilworth & -9240 & & 2468 & \\
\hline Gateway & & -471 & 2284 & \\
\hline$G$ & & & & 2420 \\
\hline $\mathrm{CL}$ & & & & 0 \\
\hline Mather & & & 2247 & \\
\hline$M$ & & & & 4668 \\
\hline Nemacolin & & & 4464 & \\
\hline N1 & & & & 416 \\
\hline N2 & & & & 5242 \\
\hline Pitt Gas & & -202 & 725 & \\
\hline Robena & -2700 & & 5387 & \\
\hline $\mathrm{R}$ & & & & -7943 \\
\hline Total & -11940 & -673 & 20556 & -7943 \\
\hline
\end{tabular}

Table 3.5. Parameters for Equations 2 and 3

$\begin{array}{ccccc}V I_{(o)}(\mathrm{mm} / \mathrm{d}) & d_{1}(\mathrm{~m}) & \lambda & \varepsilon & \lambda_{\min } \\ 0.67 & 33 & 0.021 & 2 & 0.023\end{array}$


recharge rates for mines in the Pittsburgh coal (Table 3.1) were used to determine the form of the depth-dependent vertical infiltration model for depths below $d_{1}$ (Eq. 3.3; Table 3.5; Figure 3.7) Applying the depth-dependent vertical infiltration model to the overburden isopach produced a vertical infiltration estimate that exceeds total pumping by approximately 60 percent (Table 3.4). This discrepancy suggests that barrier leakage to adjacent mines outside the study area may also occur. The pool level in Clyde mine (Figure 3.2) was approximately $10 \mathrm{~m}$ above the groundwater elevation in Gateway in fall 2012, which indicates that Clyde could only act as a source, not as a sink, of barrier leakage for Gateway. Similarly, the pool in Warwick \#2 is maintained by pumping at an elevation of ca. $230 \mathrm{~m}$, well above the mine-water control elevation in Robena mine (215 m). However, both Humphrey and Shannopin mines (Figure 3.2) contain pools at lower elevations (157 and 190 meters, respectively) than the control elevation in Robena, yet they are also separated from Robena by relatively wide barriers of limited length, and likely neither mine receives significant leakage from Robena.

Warwick \#3 mine is in the Sewickley bed, about $30 \mathrm{~m}$ above the Pittsburgh, and its location straddles the barrier pillar between Robena and Shannopin mines (Figures 3.2 and 3.4)..It closed due to significant groundwater inflow through vertical fractures connecting it to the underlying Shannopin mine (Miller, 2000). The pool in Shannopin has since been lowered by pumping to an elevation below $190 \mathrm{~m}$ (2012) to allow new mining in the Sewickley bed making it a potential sink for leakage from Robena. It is interpreted that fractures between both Robena and Shannopin and the overlying Warwick \#3 mine provide pathways for vertical leakage between Robena and Shannopin via the Sewickley-bed workings. Any groundwater leaked into 


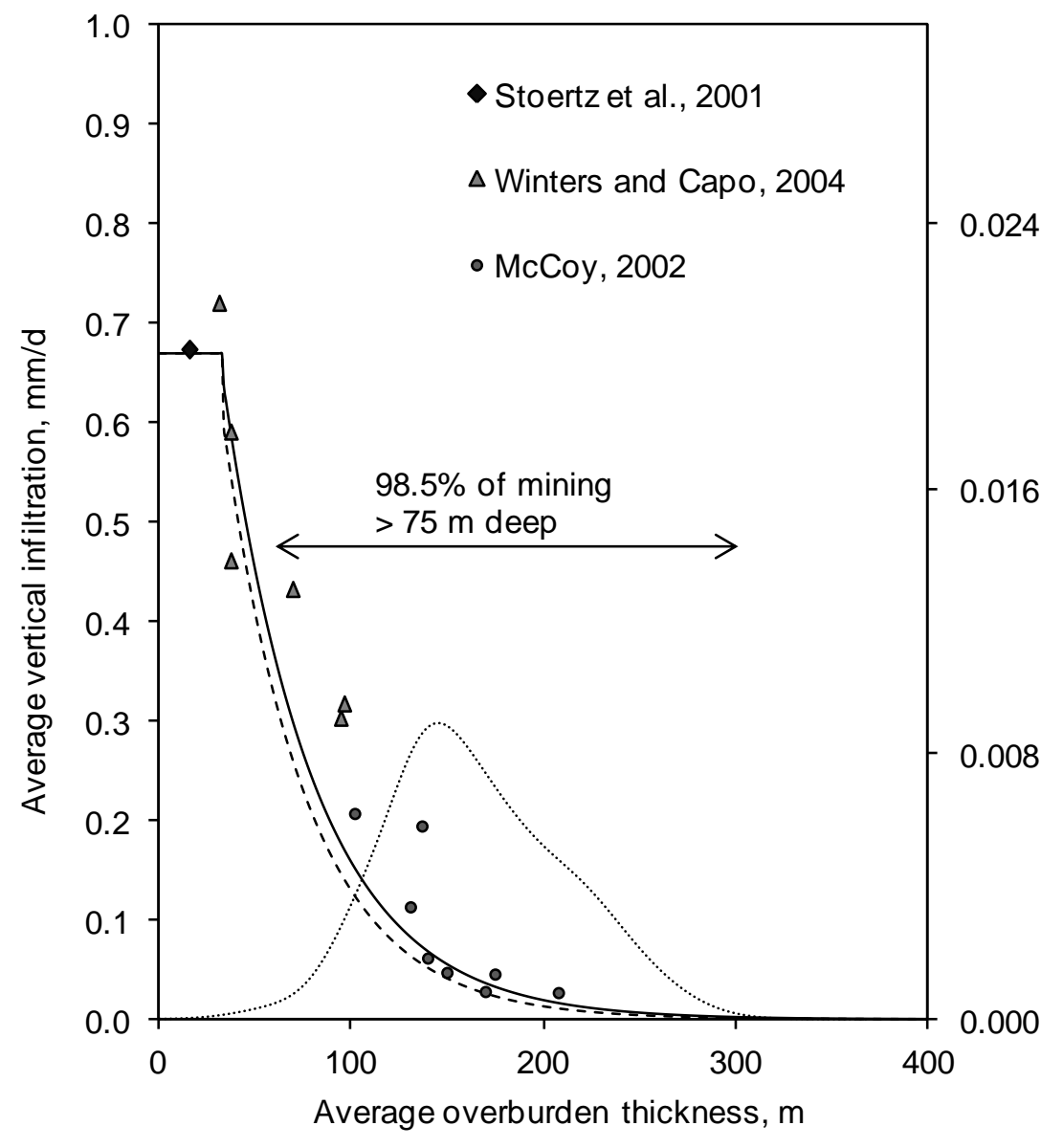

Figure 3.7 Estimates of groundwater vertical infiltration to underground mines, fitted using Equations 2 and 3: $\mathrm{VI}_{(\mathrm{d})}=\mathrm{VI}_{(0)}\left(\mathrm{d} \leq \mathrm{d}_{1}\right), \mathrm{VI}_{(\mathrm{d})}=\mathrm{VI}_{(0)} \mathrm{e}^{-\lambda(\mathrm{d})}\left(\mathrm{d}>\mathrm{d}_{1}\right)(\lambda$ solid line and $\lambda_{\min }$ dashed). The density function (dotted line) describes overburden thickness for mines within the study area. 
Shannopin is removed by pumping. Leakage from Robena to Shannopin via Warwick \#3 is estimated thus:

$$
\mathrm{L}_{\mathrm{W}}=\sum_{\mathrm{i}=0}^{\mathrm{n}}\left(\mathrm{VI}_{\mathrm{i}}+\mathrm{P}_{\mathrm{i}}+\Delta \mathrm{S}_{\mathrm{i}}\right)
$$

where $\mathrm{L}_{\mathrm{W}}$ is vertical leakage from Robena to Warwick \#3 (Table 3.4).

Estimated additions to confined storage amounted to $471 \mathrm{~m}^{3} / \mathrm{d}$ within Gateway and $27 \mathrm{~m}^{3} / \mathrm{d}$ in Pitt Gas, while $175 \mathrm{~m} / \mathrm{d}$ were added to storage within the approximately $50,000-\mathrm{m}^{2}$ unconfined area of Pitt Gas (Tables 3.4 and 3.6). Daily pumping volumes for Dilworth and Robena were

estimated by averaging annual total volumes (Table 3.7). Barrier leakage estimates were made for the two mines with multiple adjacent mines, Crucible and Nemacolin, assuming that the barriers are intact, homogeneous, and without hydraulically compromised areas (Table 3.8). These leakage estimates suggest that groundwater in Nemacolin should leak primarily to Robena, while a small portion leaks to Dilworth. Similarly, Crucible is expected to leak most of its groundwater to Dilworth with some going to Nemacolin.

\subsubsection{Groundwater Flow Modeling}

Data regarding coal-mine aquifers are often limited to the spatial extent of mining, sparse groundwater-head measurements, and discharge volumes while conditions within mines and of inter-mine barrier pillars are unknown. This lack of information requires a number of assumptions in order to conceptualize groundwater flow within and between mines that comprise coal-mine aquifers. Generally, all groundwater originates as vertical infiltration downward into the mines and flows toward groundwater extraction pumps in Dilworth and Robena. Vertical 
Table 3.6. Parameters for $S_{y}$ calculations

\begin{tabular}{cccc}
$\beta(\mathrm{m})$ & $b(\mathrm{~m})$ & $E_{m}$ & $C_{s}$ \\
\hline 20 & 2.0 & 0.80 & 0.80 \\
\hline
\end{tabular}

Table 3.7. Monthly (2011) extraction volumes for pumps in the study area $\left(1000 \mathrm{~m}^{3}\right)$

\begin{tabular}{lccccccccccccc} 
Mine & Jan & Feb & Mar & Apr & May & Jun & Jul & Aug & Sep & Oct & Nov & Dec & Annual \\
\hline Robena & 260 & 40.9 & 0.68 & 0 & 175 & 295 & 216 & 0 & 0 & 0 & 0 & 0 & 988 \\
Dilworth & 250 & 368 & 303 & 344 & 300 & 344 & 407 & 231 & 0 & 323 & 249 & 251 & 3372 \\
Total & & & & & & & & & & & & & 4360 \\
\hline
\end{tabular}

Table 3.8. Barrier leakage estimates for mines with multiple adjacent mines (refer to Figure 3.2 for barrier locations; refer to text for parameter definitions)

\begin{tabular}{cccc}
$\begin{array}{c}\text { Barrier } \\
\text { ID }\end{array}$ & Mines & $\begin{array}{c}h \\
(\mathrm{~m})\end{array}$ & $\begin{array}{c}L_{B} \\
\left(\mathrm{~m}^{3} / \mathrm{d}\right)\end{array}$ \\
\hline C1 & Crucible-Dilworth & 19 & 223.8 \\
C2 & Crucible-Nemacolin & 2.7 & 40.8 \\
& Crucible Total & & 264.5 \\
N1 & Nemacolin-Dilworth & 16.3 & 83.4 \\
N2 & Nemacolin-Robena & 24.3 & 801.5 \\
& Nemacolin Total & & 884.9 \\
\hline
\end{tabular}


infiltration is inferred to be dependent upon overburden thickness, with the highest vertical infiltration rates occurring in Pitt Gas and Robena below stream valleys, while the lowest rates occur under hills and ridges (Figure 3.8). Relatively small volumes of the groundwater infiltrating Pitt Gas and Gateway are assumed to be retained as storage within these mines, while the remainder leaks through the barrier between Gateway and Mather joining vertical infiltration received by the later mine before leaking into Dilworth through barrier segment M (Figure 3.9). Vertical infiltration entering Crucible leaks to both Dilworth and Nemacolin, similarly, vertical infiltration that enters Nemacolin leaks to Dilworth and Robena (Figure 3.9). Based on anecdotal reports by miners (Miller, 2000) and on mass balance discrepancy, some additional

flow is suspected to occur upward through vertical fractures from Robena to Warwick \#3 in the Sewickley bed(Figure 3.9). It is assumed that the Gateway/Clyde barrier (north), the east barriers of Crucible and Nemacolin (east), and the deep mining faces of Gateway and Robena (west) all are effectively no-flow boundaries. Groundwater movement to and/or from surrounding un-mined coal is assumed insignificant relative to other portions of the FMB. Similarly, barrier leakage between the study area and surrounding mines (Clyde, Warwick \#2, Humphrey, and Shannopin) is thought to be small and have no effect on overall flow directions.

\subsubsection{Modeling Approach}

The USGS Modular Finite-difference Flow Model (MODFLOW-2000) (Harbaugh et al., 2000) was employed to create a steady-state model of post-flooding groundwater conditions under pumping control in the year 2012. Pre-and post-processing were conducted utilizing Groundwater Vistas version 6.22. At this time, all mines in the study area except Pitt Gas and 


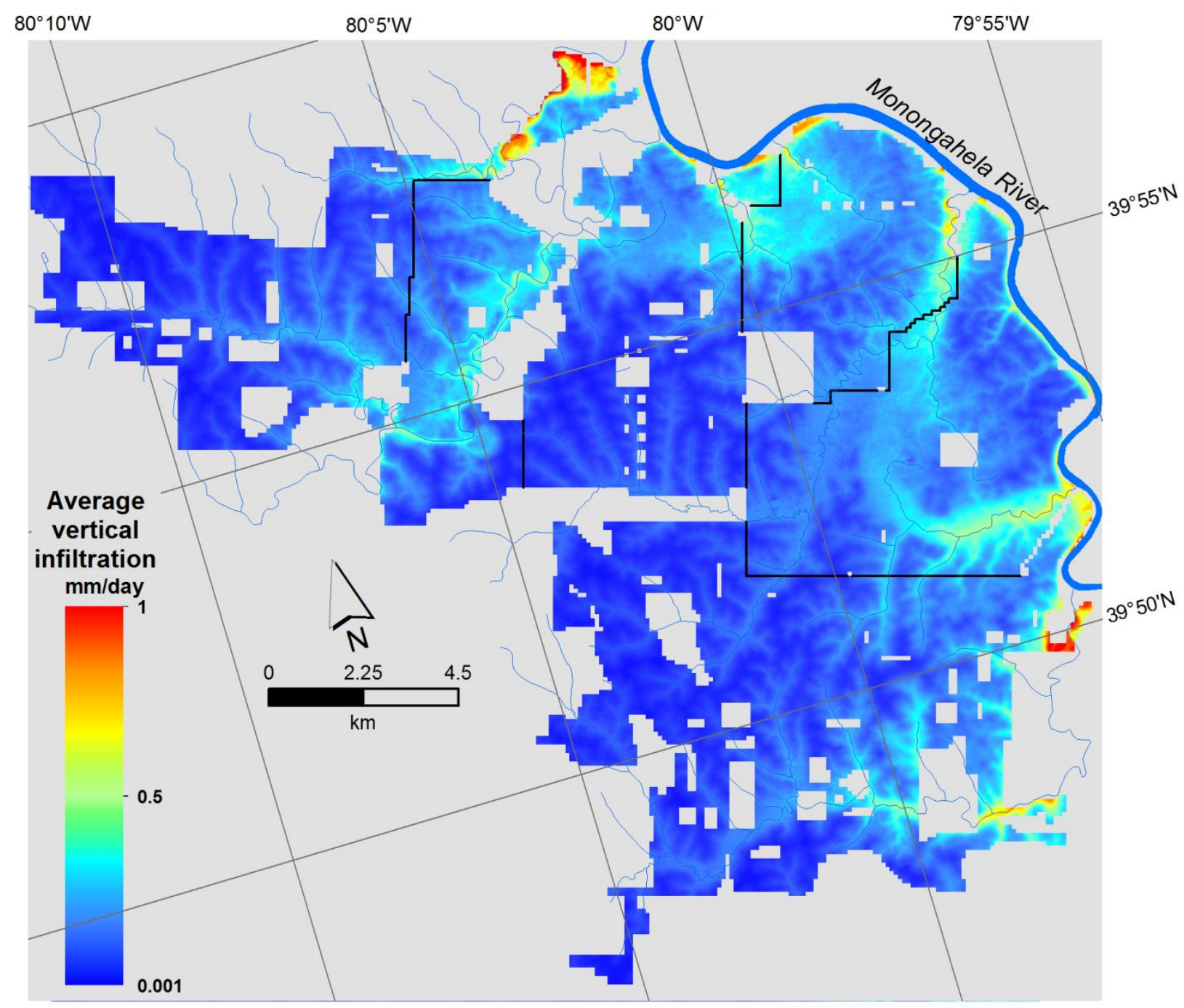

Figure 3.8. Vertical infiltration rates applied to the groundwater flow model. This and later maps have been rotated from geographic north to align with the model grid. 


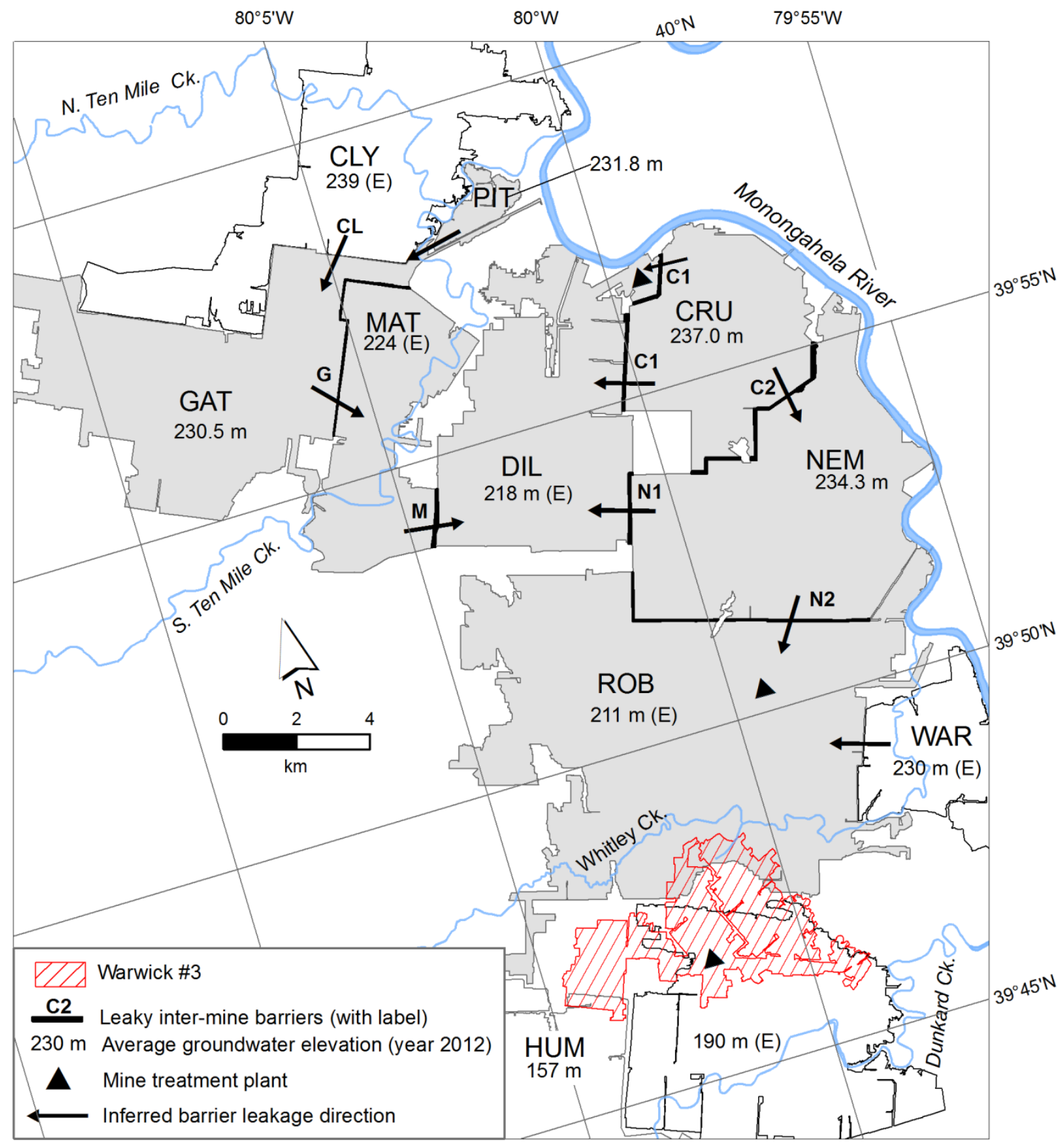

Figure 3.9. Conceptual model of groundwater flow across leaky barriers. 
Gateway are thought to have been fully flooded and at seasonally-fluctuating, but inter-annual steady-state. The goal of the model was to determine groundwater-flow paths and rates within and between mines in the study area.

The model employs a $100 \times 100$ meter 3-layer grid rotated 16 degrees to align with most intermine barriers (Figure 3.10). Internal coal pillars $>10,000 \mathrm{~m}^{2}$ area were also considered no-flow regions. Flow is, however, known to occur across narrow inter-mine barriers separating the mines; the magnitude and direction of this leakage were obtained by calibration using horizontal flow barrier (HFB) cells. HFB cells allow modeling of barrier thicknesses greater or less than grid spacing and variation of local barrier hydraulic conductivities $\mathrm{K}_{\mathrm{B}}$ (Figure 3.10). Initial $\mathrm{K}_{\mathrm{B}}$ values were $0.078 \mathrm{~m} /$ day, a value based on field calculations of McCoy et al.(2006).

All three layers are confined $(\mathrm{LAYCON}=3)$ and represent groundwater flow within the mined area, as well as in overlying collapse and fracture zones, e.g. well beneath the shallow groundwater flow system. The un-flooded portion of Robena up-dip of its water-table surface was not modeled. Vertical infiltration and barrier leakage occurring in this region were added to adjacent active cells in order to maintain the FMB.

\subsubsection{Boundaries and Parameterization}

Boundaries for the model include a recharge (vertical infiltration) boundary at the top of model layer 1, no-flow cells at the bottom of layer 3, and no-flow cells representing un-mined coal at the perimeter of the model. A single constant-head cell was located in reasonable proximity to the pumps in both Dilworth and Robena, at the elevation of the average pool control elevation 


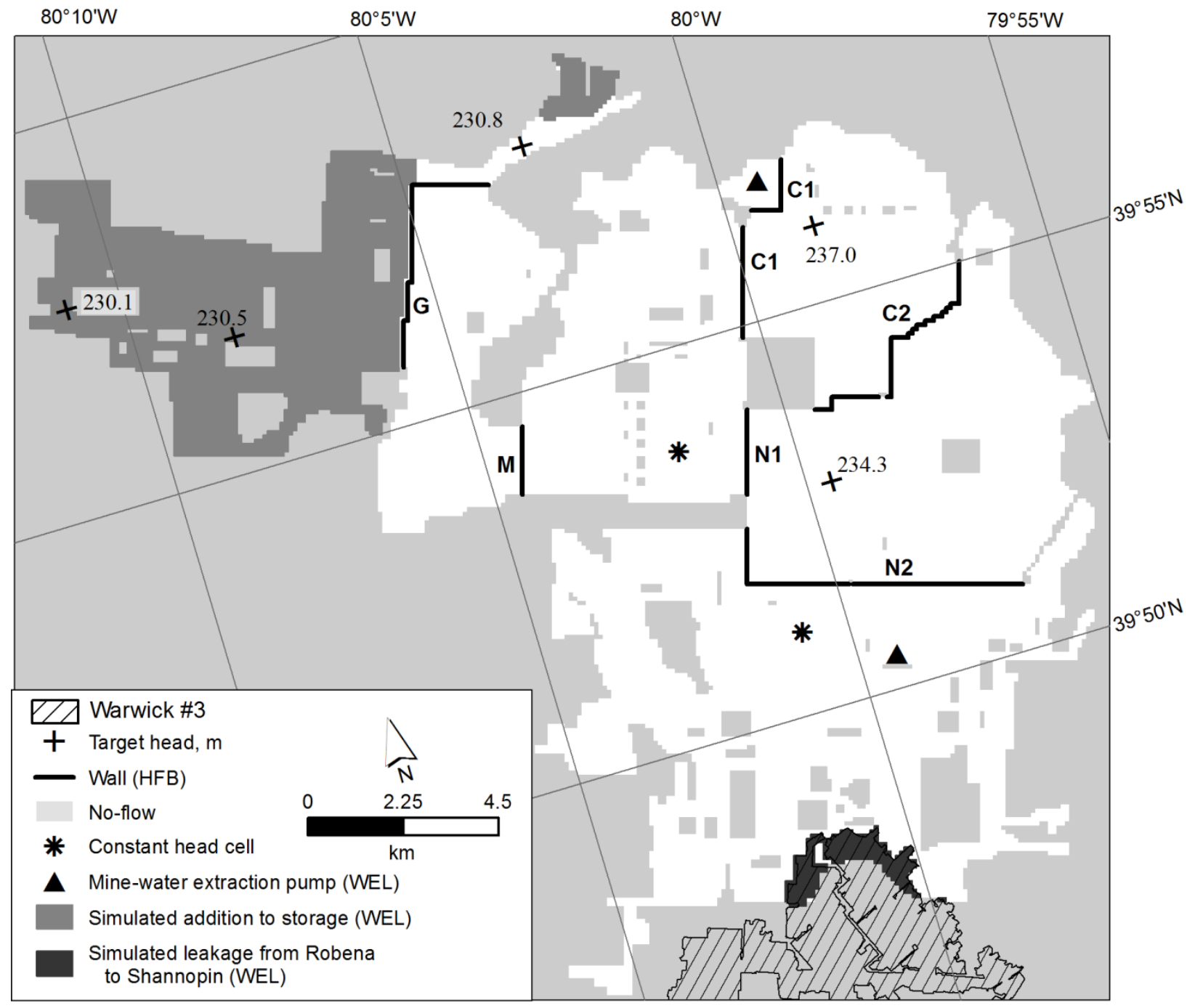

Figure 3.10. Boundary condition types and locations within the groundwater-flow model. WEL cells for storage and leakage are located in Layer 1; extraction wells, constant heads, and targets are all in Layer 3. 
maintained in these mines during 2011 (Table 3.9), as an aid in calibration. The constant head cells were removed once calibration was achieved.

MODFLOW WEL-package (specified-flux) cells were utilized to simulate pumping from Dilworth and Robena; movement of groundwater into storage within nearly-flooded Gateway and Pitt Gas; and upward leakage from Robena into the overlying Warwick \#3 mine and, ultimately, into Shannopin to the south (Figure 3.10). Average daily pumping rates for Dilworth and Robena were estimated using operator-supplied values for 2011 (Table 3.7). The calculated daily increase in storage within Pitt Gas and Gateway was distributed across 3,951 WEL cells

(Table 3.4, Figure 3.10). Barrier leakage into Robena from Nemacolin and vertical infiltration to Robena in excess of pumping from Robena were distributed among 233 WEL cells in Robena to simulate leakage to Warwick \#3 (Table 3.4).

Layers 2 and 3 were assigned isotropic K values of $1000 \mathrm{~m} /$ day to simulate large conduits associated with mains entries and highly conductive gob zones. In Layer $1, \mathrm{~K}_{\mathrm{H}}$ was assigned a value of $1.0 \mathrm{~m} /$ day, while $\mathrm{K}_{\mathrm{V}}$ was assigned a value of $100 \mathrm{~m} /$ day reflecting Layer 1 is thought to contain significant vertical fracturing.

The top of Layer 1 is where groundwater enters active cells in the model by vertical infiltration. The per-cell infiltration rate was calculated at 100x100 $\mathrm{m}^{2}$ grid scale using local overburden thickness and the depth-dependent vertical infiltration relationship (Figures 3.7 and 3.8).

\subsubsection{Calibration}

Although groundwater elevations vary seasonally in all these mines, average-annual elevations within monitoring wells during 2012 (Table 3.9, Figure 3.3) were used for calibration. 
Table 3.9. Observed and modeled groundwater elevation heads in meters

\begin{tabular}{lccccl} 
Target & Min. & Max. & Avg. $^{*}$ & $\sigma$ & Modeled \\
\hline CRU & 236.3 & 237.5 & 237.0 & 0.35 & 237.0 \\
GAT1 & 228.0 & 233.4 & 230.5 & 1.46 & 230.6 \\
GAT2 & 227.5 & 233.0 & 230.1 & 1.62 & 230.6 \\
NEM & 233.6 & 234.9 & 234.3 & 0.33 & 234.4 \\
PIT & 229.4 & 235.0 & 231.8 & 1.42 & 230.9 \\
DIL & 213.6 & 219.9 & 217.4 & 1.5 & $217.0^{* *}$ \\
ROB & 209.0 & 213.1 & 211.3 & 1.1 & $211.0^{* *}$ \\
\hline
\end{tabular}

* Year 2011 for DIL and ROB, 2012 for all others.

** Values assigned to constant head cells during initial calibration. 
Calibration was accomplished by iteratively adjusting $\mathrm{K}_{\mathrm{B}}$ of individual inter-mine barriers until modeled heads were within 1.0 meters of target values (Table 3.9). The calibration process also required reducing the volume of groundwater extracted by WEL cells for $\Delta \mathrm{S}$ within Gateway and Pitt Gas (Table 3.4). A head change criterion of $10^{-5} \mathrm{~m}$ and mass balance error of 0.007 percent were considered sufficient for convergence.

\subsubsection{Model Results}

Calibration required increasing $\mathrm{K}_{\mathrm{B}}$ values for barrier sections by 1 to 3 orders of magnitude over initial estimates(Table 3.10). The calibrated potentiometric contours indicate flow within individual mines from relatively high vertical infiltration areas towards leaky barriers, pumps,

and the WEL cells that simulate leakage into the overlying Warwick \#3 mine (Figure 3.11). These contours deflect at leaky inter-mine barriers as a result of differences in conductivity between mines and barriers. In short, the barriers tend to maintain individual pools within each mine that may receive leakage or leak into one or more adjacent mines. The potentiometric contours may be analyzed to show the locations of flow divides that partition the study area into a number of catchments, while particle traces indicate that groundwater may move through multiple mines before discharging (Figure 3.11).

\subsection{Discussion}

Results indicate that post-mining hydrogeology within flooded and flooding underground mine complexes is amenable to numerical modeling. Known data including groundwater elevations, mine maps, and pumping volumes can be combined with vertical infiltration estimates to allow calculation of barrier leakage rates and flow patterns within and between adjacent mines. 
Table 3.10. Calibrated $K_{B}$ values

\begin{tabular}{ccc} 
Inter-mine barrier & $\mathrm{K}(\mathrm{m} / \mathrm{d})$ & $\%$ McCoy $^{*}$ \\
\hline $\mathrm{C} 1$ & 0.53 & 700 \\
$\mathrm{C} 2$ & 2.00 & 2600 \\
$\mathrm{G}$ & 0.55 & 700 \\
$\mathrm{M}$ & 25.00 & 32000 \\
$\mathrm{~N} 1$ & 0.30 & 400 \\
$\mathrm{~N} 2$ & 0.49 & 600 \\
\hline${ }^{*}$ Average K for intact coal barriers: $0.078 \mathrm{~m} / \mathrm{d}$ (McCoy \\
et al., 2006).
\end{tabular}




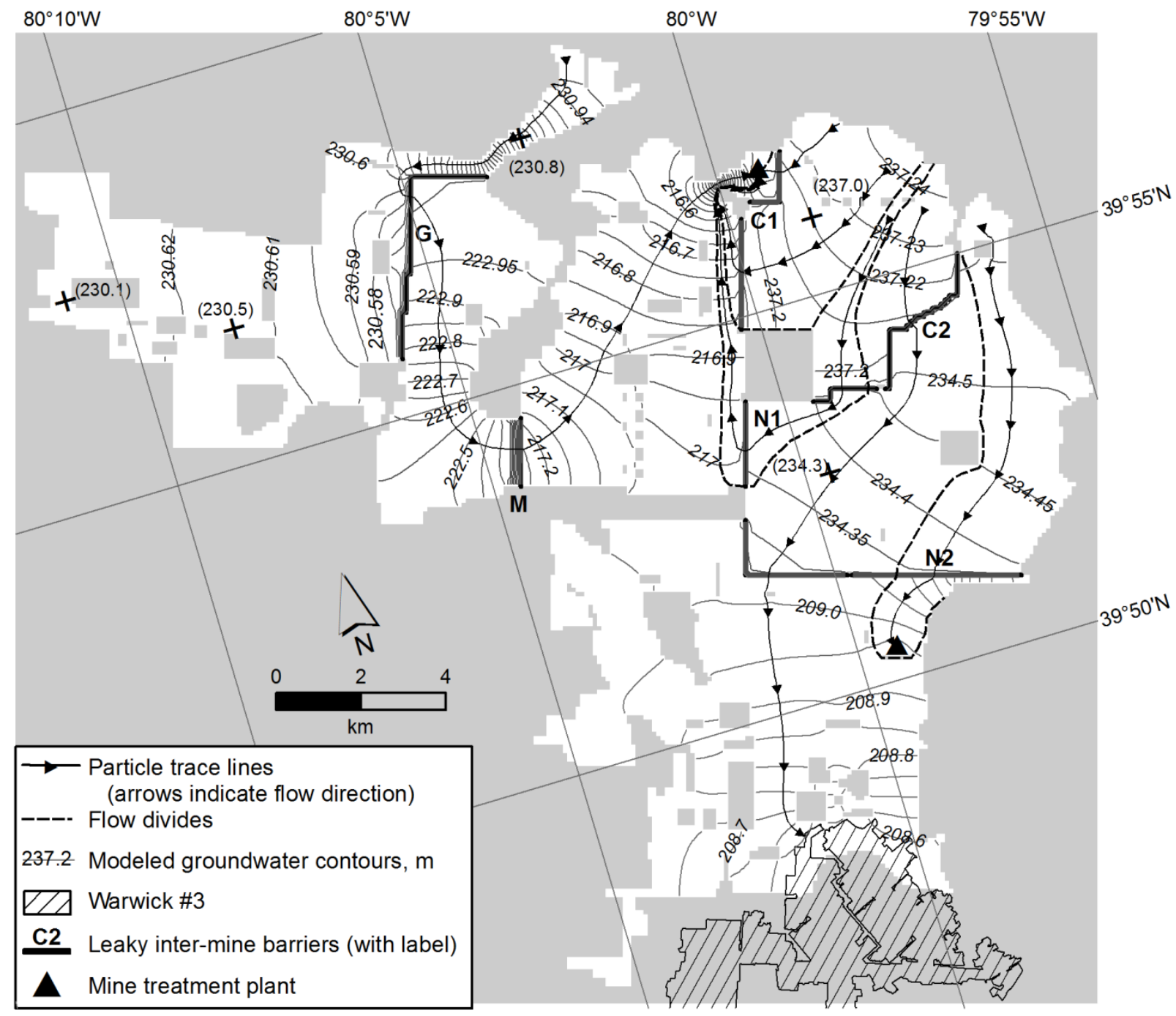

Figure 3.11. Calibrated steady-state hydraulic heads for Layer 3. Symbology as for Figure 9. 
Results also indicate the potential for compromised barriers with leakage rates significantly greater than would be observed due to homogeneous barrier leakage alone.

Calibrated $\mathrm{K}_{\mathrm{B}}$ values suggest that coal barriers within the study area are more conductive than those in the Pittsburgh bed studied by McCoy et al. (2006). It is likely that these barriers are hydraulically compromised by un-mapped entries between mines, boreholes, or subsidence. The actual $\mathrm{K}_{\mathrm{B}}$ values for intact coal barriers may well be similar to those determined by McCoy et al. (2006), but the significantly greater calibrated $K_{B}$ values are the result of averaging relatively low-K $\mathrm{K}_{\mathrm{B}}$ barrier segments with relatively highly-conductive compromised barrier sections. The distribution of barrier leakage out of Nemacolin and Crucible into adjacent mines indicates variation in barrier hydraulic properties and geometry. The calibrated $\mathrm{K}_{\mathrm{B}}$ values for barriers N1 and N2 are similar (Table 3.10), which suggests that the significantly greater barrier leakage from Nemacolin to Robena than from Nemacolin to Dilworth (Table 3.4) results from the greater length and narrower width of $\mathrm{N} 2$ relative to $\mathrm{N} 1$ (Table 3.3), as well as the steeper head gradient between Nemacolin and Robena (the N2 barrier) compared to Nemacolin and Dilworth (the N1 barrier; Table 3.9 and Figure 3.11). The $\mathrm{C} 1$ and $\mathrm{C} 2$ barriers are of similar width, but $\mathrm{C} 2$ is longer and more conductive, nevertheless Crucible leaks more water into Dilworth than it does to Nemacolin, which suggests that the higher head gradient between Crucible and Dilworth is the primary control on barrier leakage out of Crucible (Tables 3.3, 3.4, 3.9, and 3.10). The calibrated $K_{B}$ for barrier $M$ is an order of magnitude higher than all other $K_{B}$ values calculated in the model (Table 3.10), yet M is also the widest and shortest barrier (Table 3.3). These and other 
observations are interpreted as strong evidence that many barrier sections in this study area are hydraulically compromised and not exhibiting simple matrix- or fracture- flow.

Calibrated groundwater-elevation contours indicate flow toward the pumps in Dilworth and Robena and toward WEL cells in Robena that simulate leakage to Warwick \#3, and also locate several flow divides within the study area (Figure 3.11). The locations of the flow divides reflect variation in barrier hydraulic characteristics and geometry and outline catchments that illustrate the partitioning of groundwater between the different sinks. The catchments show that groundwater infiltrating any individual mine may flow through multiple adjacent mines before reaching a sink (Figure 3.11). For example, vertical infiltration entering Pitt Gas flows though Gateway, Mather, and most of Dilworth before being extracted from Dilworth, while vertical infiltration that enters Crucible may leak directly to Dilworth, leak to Nemacolin then to Dilworth, or leak to Nemacolin, flow through Robena, and then pass through Warwick \#3 in route to pumps in Shannopin. The calibrated groundwater-elevation contours also depict relatively low head gradients within individual mines as well as significant differences between $\mathrm{K}_{\mathrm{B}}$ and $\mathrm{K}$ in the collapsed zone, indicated by the deflection of contour lines near barriers. Both mimic shallow hydraulic gradients observed in underground mine pools (Aljoe and Hawkins, 1992).

The model indicates that groundwater elevations in some contiguous flooded mines may achieve seasonally-varying, inter-annual equilibrium when barrier leakage from these mines to adjacent mines is sufficient to offset vertical infiltration. Crucible and Nemacolin maintain relatively constant groundwater elevations by discharging to adjacent mines. The current conditions in Mather are unknown, but groundwater elevations in that mine were similarly thought to be at 
equilibrium as inflowing water leaks to Dilworth. During this study, Pitt Gas and Gateway were still flooding, yet leaking considerable volumes of water to Mather. At present, it is uncertain whether these mines will achieve steady state by barrier leakage or ultimately discharge to the surface.

The depth-dependent vertical infiltration model yields infiltration rates that decrease exponentially with increasing depth, whereas earlier methods tend to apply uniform recharge rates to shallow areas while assuming vertical infiltration in negligible in relatively deep (> 75 m) mined areas. Applying recharge only to thin overburden areas $(<75 \mathrm{~m})$ resulted in rates orders of magnitude greater than values reported for relatively shallow mines. The vertical infiltration model therefore offers an improved method when deep mining becomes a significant portion of the total mined area. Yet, there is some uncertainty in the vertical infiltration model. Within the study area, modeled vertical infiltration exceeds extraction pumping by roughly 40 percent (Table 3.4). The model can be adjusted to site-specific information by changing the $\lambda$ value (Eq. 3.3). A minimum $\lambda\left(\lambda_{\min }\right)$ value was attained by setting vertical infiltration equal to pumping and additions to storage within Gateway and Pitt Gas and ignoring barrier leakage into or out of the study area, yet calibrating the groundwater-flow model to $\lambda_{\text {min }}$ required groundwater flow from Robena to Nemacolin against the head gradient. It is likely that the actual $\lambda$ value is between 0.021 and 0.023 within the study area, yet further refinement of $\lambda$ is considered unwarranted given uncertainties in barrier leakage rates, vertical leakage from Robena to Warwick \#3, and the potential for barrier leakage between the study area and surrounding mines. 


\subsection{Chapter Conclusions}

- Post-closure mine flooding often results in complex hydrogeological conditions among groups of adjacent mines. These conditions are influenced by vertical-infiltration, barrier-leakage, and pumping rates.

- The post-mining hydrogeology of mine complexes is amenable to numerical modeling given known data including groundwater-elevation heads, pumping rates, and the geospatial extent of mining.

- Current recharge estimation for underground mines assumes that recharge only occurs in areas with relatively thin $(<75 \mathrm{~m})$ overburden and neglects leakage to deeper mined areas. This restriction results in increasingly high recharge rates as the depth of mining increases.

- The depth-dependent vertical infiltration model offers an improved method for estimating recharge to underground mines especially as the area of relatively thick (> $75 \mathrm{~m}$ ) overburden increases. The model is amenable to modification for site-specific conditions in other mine complexes.

- Calibrated coal-barrier hydraulic conductivity values are greater than those reported by McCoy et al (2006) by 4x to 320x. The causes for these increases are unknown, but it is speculated that un-mapped entries between mines, boreholes, or other conditions have resulted in hydraulic compromise of barrier integrity.

- The calibrated groundwater-flow model indicates that barrier leakage is sufficient to offset vertical infiltration within individual mines making it possible for groundwater extraction pumps in one or more mines to control pool elevations in multiple adjacent 
mines. The model further indicates that vertical leakage may play a role in the FMB of mines that are overlying or underlying other mined coal beds. Vertical leakage is especially likely when the inter-burden separating mined beds lies within the fractured zone.

The results of this study have implications for other flooding and flooded underground mines including the post-closure treatment of mine water. Failure to consider post-flooding hydrogeological conditions including potential inter-mine connections among adjacent mines may result in poorly sited pumps, undersized waste-water treatment plants, and underestimation of water-treatment budgets.

\subsection{Chapter References}

Adams, R. and Younger, P. L., 2001, A strategy for modeling ground water rebound in abandoned deep mine systems: Groundwater, Vol. 39, No. 2, pp. 249-261.

Aljoe, W. W. and Hawkins, J. W., 1992, Application of aquifer testing in surface and underground mines: Groundwater Management, Vol. 13, pp. 541-555.

Banks, D.; Younger, P. L.; Arnesen, R.; Iversen, E. R.; and Banks, S. B., 1997, Mine-water chemistry: the good, the bad and the ugly: Environmental Geology, Vol. 32, No. 3, pp. $157-174$.

Beardsley, R. W.; Campbell, R. C.; and Shaw, M. A., 1999, Chapter 20 Appalachian Plateaus, In C. H. Shultz (Editor), The Geology of Pennsylvania: Pennsylvania Geological Survey, Harrisburg and Pittsburgh Geological Survey, Pittsburgh, PA, 888 p. 
Booth, C. J., 1986, Strata-movement concepts and the hydrogeological impact of underground coal mining: Groundwater, Vol. 24, No. 4, pp. 507-515.

Donovan, J. J. and Fletcher, J., 1999, Hydrogeological and Geochemical Response to Mine Flooding in the Pittsburgh Coal Basin, Southern Monongahela River Basin: Project WV132, Report to the U. S. Environmental Protection Agency, 47 p.

Edmunds, W. E.; Skema, V. W.; and Flint, N. K., 1999, Chapter 10 Pennsylvanian, In C. H. Shultz (Editor), The Geology of Pennsylvania: Pennsylvania Geological Survey, Harrisburg and Pittsburgh Geological Survey, Pittsburgh, PA, 888 p.

Fenneman, N. M., 1938, Physiography of eastern United States, McGraw-Hill, New York, NY, $714 \mathrm{p}$.

Harbaugh, A. W.; Banta, E. R.; Hill, M. C.; and McDonald, M. G., 2000, The U. S. Geological Survey modular ground-water model -- user guide to modularization concepts and the ground-water flow process: U.S. Geological Survey Open-File Report 00-92, 121 p.

Harlow, G. E., Jr. and Lecain, G. D., 1993, Hydraulic Characteristics of, and Groundwater Flow in, Coal Bearing Rocks of Southwestern Virginia: U.S. Geological Survey Water Supply Report 2388, 36 p.

Hawkins, J. W. and Dunn, M., 2007, Hydrologic characteristics of a 35-year-old underground mine pool: Mine Water and the Environment, Vol. 26, No. 3, pp. 150-159.

Hennen, R. V. and Reger, D. B., 1913, Marion, Monongalia, and Taylor Counties: West Virginia Geological and Economic Survey, Morgantown, WV, 844 p. 
Hobba, W. A., 1991, Relation of Fracture Systems to Transmissivity of Coal and Overburden Aquifers in Preston County, West Virginia: U.S. Geological Survey Water-Resources Investigations Report 89-4137, 24 p.

Kendorski, F. S., 1993, Effect of high-extraction coal mining on surface and ground waters. In Proceedings, 12th International Conference on Ground Control in Mining, West Virginia University, Morgantown, WV, pp. 412-425.

Kipp, J. A. and Dinger, J. S., 1987, Stress-relief facture control of ground-water movements in the Appalachian Plateaus. Presented at the NWWA Focus Conference on Eastern Regional Ground-water Issues, July 1987, Burlington, VT, 6 p.

Kozar, M. D., and Mathes, M. V., 2001, Aquifer-Characteristics Data for West Virginia: U.S. Geological Survey Water-Resources Investigations Report 01-4036, 74 p.

Leavitt, B. R., 1999, Mine flooding and barrier pillar hydrology in the Pittsburgh basin. In Proceedings 16th Annual International Pittsburgh Coal Conference, Pittsburgh, PA.

Light, D. D. M., 2001, A Hydrogeological and Hydrogeochemical Characterization of the Truetown Mine Discharge: Unpublished M.S. Thesis, Department of Geological Sciences, Ohio University, Athens, OH, 271 p.

McCoy, K. J., 2002, Estimation of Vertical Infiltration into Deep Pittsburgh Coal Mines of WVPA: A Fluid Mass Balance Approach: Unpublished M.S. Thesis, Department of Geology and Geography, West Virginia University, Morgantown, WV, 151 p. 
McCoy, K. J.; Donovan, J. J.; and Leavitt, B. R., 2006, Horizontal hydraulic conductivity estimates for intact coal barriers between closed underground mines: Environmental \& Engineering Geoscience, Vol. 12, No. 3, pp. 273-282.

McDonough, K. M.; Lambert, D. C.; Mugunthan, P.; and Dzombak, D. A., 2005, Hydrologic and geochemical factors governing chemical evolution of discharges from an abandoned, flooded, underground coal mine network: Journal of Environmental Engineering, Vol. 131, No. 4, pp. 643-650.

Miller, L., 2000, Warwick Coal Mines: Greene County, Pennsylvania, Rita Miller Publishing, $256 \mathrm{p}$.

Palchik, V., 2002, Influence of physical characteristics of weak rock mass on height of caved zone over abandoned subsurface coal mines: Environmental Geology, Vol. 42, No. 1, pp 92-101.

Palchik, V., 2003, Formation of fractured zones in overburden due to longwall mining: Environmental Geology, Vol. 44, No. 1, pp. 28-38.

Peng, S. S., 1986, Coal Mine Ground Control, 2nd Ed., John Wiley \& Sons, New York, NY, 491 p.

Pigati, E. and Lopez, D. L., 1999, Effect of subsidence on recharge at abandoned mines generating acidic drainage: the Majestic Mine, Athens County, $\mathrm{OH}$ : Mine Water and the Environment, Vol. 18, No. 1, pp. 45-66. 
Sahu, P., and Lopez, D. L., 2009, Using time series analysis of coal mine hydrographs to estimate storage, retention time, and mine-pool interconnection: Mine Water and the Environment, Vol. 28, No. 3, pp. 194-205.

Singh, M. M. and Kendorski, F. S., 1981, Strata disturbance prediction for mining beneath surface water and waste impoundments. In Proceedings of the 1st Conference on Ground Control in Mining: West Virginia University, Morgantown, WV, pp. 76-89.

Stoertz, M. W.; Hughes, M. L.; Wanner, N. S.; and Farley, M. E., 2001, Long-term water quality trends at a sealed, partially flooded underground mine. Environmental \& Engineering Geoscience, Vol. 12, No. 1, pp. 51-65.

Stoner, J. D., 1983, Probable hydrologic effects of subsurface mining: Groundwater Monitoring Review, Vol. 3, No. 1, pp 128-137.

Stoner, J. D.; Williams, D. R.; Buckwalter, T. K.; Felbinger, J. K.; and Pattison, K. L., 1987, Water Resources and the Effects of Coal Mining, Greene County, Pennsylvania, Water Resource Report 63, Pennsylvanian Geological Survey, 4th Series, 166 p.

Williams, D. R.; Felbinger, J. K.; and Squillace, P. J., 1993, Water Resources and the Hydrologic Effects of Coal Mining in Washington County, Pennsylvania, U.S. Geological Survey Open File Report 89-620,

Whitworth, K. R., 2002, The monitoring and modelling of mine water recovery in UK coalfields. In Younger, P. L., and Robins, N. S. (Editors), Mine Water Hydrogeology and 
Geochemistry. Geological Society of London Special Publication 198, London, UK, pp. $61-73$.

Winters, R. W., and Capo, R. C., 2004, Ground water flow parameterization of an Appalachian coal mine complex. Groundwater, Vol. 42, No. 5, pp. 700-710.

Wyrick, G. G., and Borchers, J. W., 1981, Hydrologic Effects of Stress-Relief Fracturing in an Appalachian Valley, U.S. Geological Survey Water-Supply Paper 2177, 51 p.

Younger, P. L., and Adams, R., 1999, Predicting Mine Water Rebound, Environment Agency R \& D Technical Report W179, Bristol, UK, 109 p. 


\section{HYDROGRAPH ANALYSIS TO INFER FLOODING HISTORY OF A SERIES OF CONTIGUOUS, BELOW-DRAINAGE, UNDERGROUND COAL MINES, IN SOUTHWEST PENNSYLVANIA}

\section{Chapter Abstract}

Hydrographic analysis shows that barrier leakage has significant impact on both the timeframe of flooding and discharge locations within contiguous, below-drainage, underground coal mines. Changes in slope of mine-pool elevation hydrographs during flooding indicate variation in the mine hydrology that are interpreted as the onset of barrier leakage or spillage between adjacent mines, or surface discharge. This study examines the water-level elevation history of several coal mines from closure until post-flooding hydrogeologic reequilibration. Equilibrated pool levels within each of the mines were induced by mechanisms including spillage, pumpage, and barrier leakage.

The timeframe of mine flooding was modeled assuming constant-rate inflow equal to activeoperations pumping rates and estimated porosity for three mines. These timeframes overestimated the actual duration of flooding by $200-275 \%$. Typical flooding duration models that use constant-rate inflows underestimate the flooding timeframe.

Porosity values were mapped in the three mines according to mining-type areas (longwall, etc.) and the porosity estimates were combined with coal-base elevation contours to model the hypsometric distribution of porosity. Observed water levels were coupled to the hypsometric model to estimate time-varying mine inflows during flooding, neglecting barrier leakage. The 
timing of temporal changes in estimated inflows in combination with the hydraulic heads at which they occurred are consistent with the interpretation of barrier leakage between mines. Results indicate that accurate prediction of the duration of mine flooding requires explicit consideration of groundwater conditions in adjacent mines. The rate and ultimate resolution of post-mining groundwater re-equilibration in such mines may be strongly influenced by characteristics of barrier leakage between adjacent mines.

\subsection{Introduction}

\subsubsection{Statement of the problem}

Following underground mining of below-drainage coal, pumping ceases resulting in groundwater rebound ("mine flooding"), Left unmanaged, such groundwater rebound may culminate in minewater discharge to the surface (Younger and Adams, 1999). Water in flooding mines with coal and/or overburden high in pyritic sulfur may contain elevated concentrations of metals and acidity, which are harmful to aquatic life (Banks et al., 1997). Accurate prediction of the duration of post-closure mine flooding and the timing and location of future surface discharge(s) would assist planning for control, treatment, and disposal of such water. This has created the need for an improved understanding of the hydrogeology of flooded mines (Aljoe and Hawkins, 1992; Younger and Adams, 1999; Stoertz et al., 2001; Whitworth, 2002).

Several methods have been developed for prediction of the duration and rate of mine flooding. These range from calculations involving void space and pumping records (Younger and Adams, 1999) to more complex models requiring data for precipitation, evaporation, surface catchment areas, mine inflows, and the location and elevation of connections to other mines (Younger and 
Adams, 1999; Adams and Younger, 2001; Banks, 2001). Such models have been applied to simulate flooding in large, interconnected, multiple-bed, below-drainage mines.

Simple volumetric models tend to underpredict the duration of flooding (Whitworth, 2002). Furthermore, in other mining districts, connections between adjacent mines causes them to flood as a cohort rather than as single mines (Younger and Adams, 1999; Donovan and Leavitt, 2004; McCoy et al, 2006). Such behavior may be related to the spatial pattern and age of mining; timing of mine closure; coal and overburden geology; and other factors. Therefore, there is a need to refine and test simple volumetric models, as well as more complex scenarios with respect to their applicability to different types of mines.

\subsubsection{Mine flooding}

Mine flooding begins when dewatering pumps are shut down after or near mine closure. In early flooding, infiltrating groundwater flows down-dip to deeper areas forming flooded areas ("pools") that tend to develop at varying elevations according to mine barrier geometry (Younger and Adams, 1999). As flooding continues, these small pools tend to rise in elevation and merge, eventually coalescing into a single pool (Burke and Younger, 2000).

The fluid mass balance for an underground mine may include inflows and outflows from multiple sources (Light and Donovan, 2015):

$$
\mathrm{Q}_{\mathrm{A}}=\mathrm{Q}_{\mathrm{V}} \pm \mathrm{Q}_{\mathrm{B}} \pm \mathrm{Q}_{\mathrm{P}}-\mathrm{Q}_{\mathrm{S}} \pm \Delta \mathrm{S}
$$

where $\mathrm{Q}_{\mathrm{A}}$ is apparent inflow [L3/T], $\mathrm{Q}_{\mathrm{V}}$ is vertical infiltration, $\mathrm{Q}_{\mathrm{B}}$ is barrier leakage, $\mathrm{Q}_{\mathrm{P}}$ is pumping, $\mathrm{Q}_{\mathrm{S}}$ is surface discharge, and $\Delta \mathrm{S}$ is change in storage. 
Inflows to underground mines may be categorized as either head-dependent or constant-rate (Younger and Adams, 1999). Head-dependent inflows vary in rate according to the difference in hydraulic head between water entering the mine, and water already in the mine. Such inflows may include vertical infiltration (recharge), vertical leakage through aquitards, and horizontal barrier leakage from adjacent mines. In unflooded areas of the mine, this head difference is between the elevation of the mine floor and the potentiometric surface across the barrier. In flooded areas, the head difference is between the mine-pool elevations across barriers (McCoy et al., 2006). Head-dependent leakage tends to decrease as pool elevations rise, because this generally reduces the difference in hydraulic head between adjacent mine pools and/or shallow groundwater (Younger and Adams, 1999; Whitworth, 2002).

Groundwater levels in mines receiving head-dependent inflows tend to rise at an exponentially slowing rate whereas constant-inflow rates produce hydrographs that reflect variations in mine geometry and porosity (Younger and Adams, 1999; Figure 4.1). Inflows tend to be constant-rate, when the head difference between external groundwater sources and mine pools does not vary over time. Such conditions are typical during active operations and during early stages of flooding, when most or all inflow occurs well up-dip of pools forming in deeper parts of a mine.

\subsubsection{Post-flooding reequilibration}

In unmanaged mines, flooding may continue until the mine-pool elevation reaches the lowestelevation "spill point," at which water may discharge to the surface or to an adjacent mine. Spill points are commonly mine entries (adits, slopes, or shafts), boreholes, or permeable fractures in 


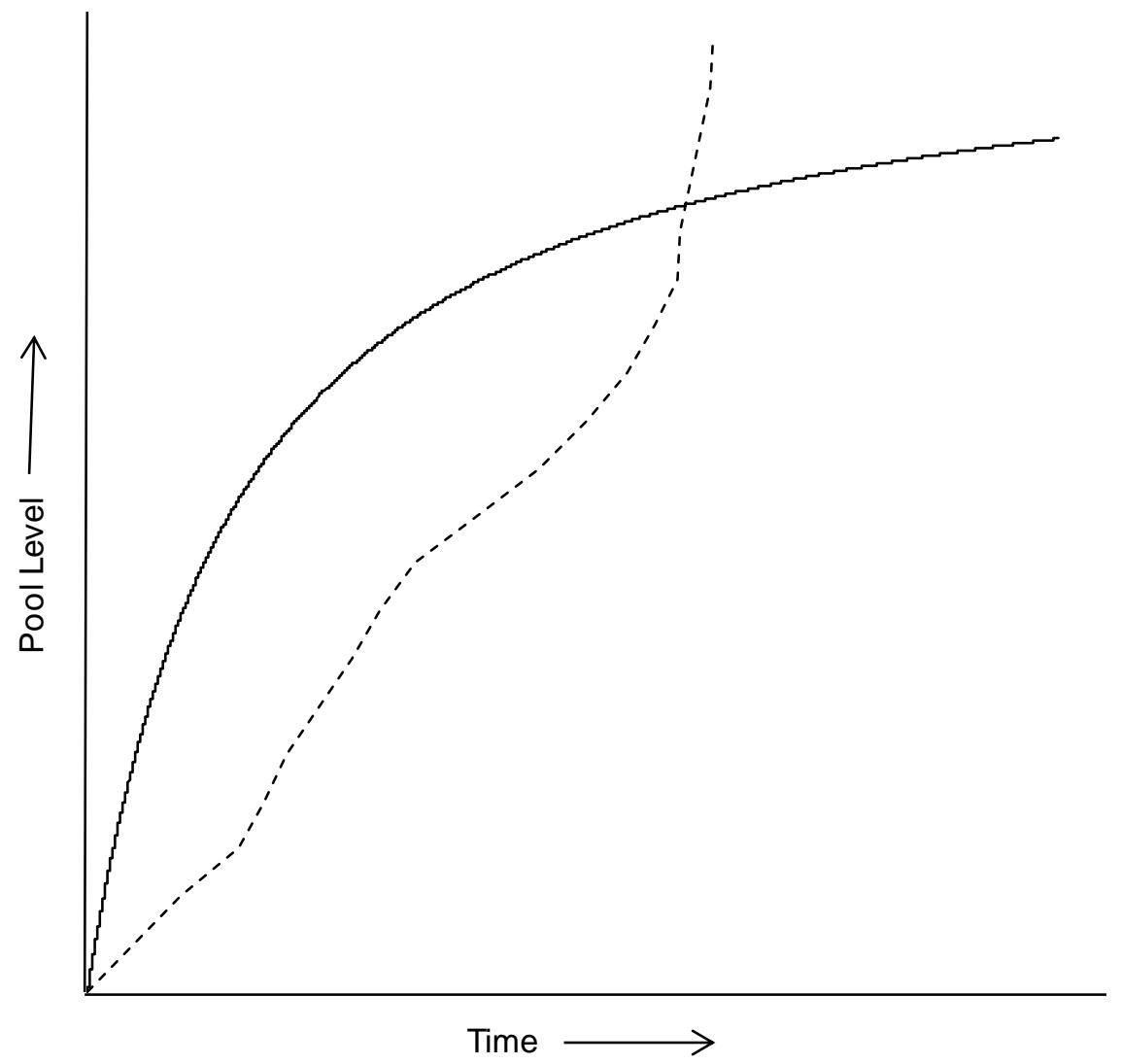

Figure 4.1. Typical groundwater recovery curves for head-dependent (solid line) and constant-rate (dashed) mine inflows (after Younger and Adams, 1999). 
either roof rocks or compromised perimeter barriers (Younger and Adams, 1999; Light and Donovan, 2015). In the latter case, flooding may resume if and when the pool elevation in the receiving mine rises to or above the spill elevation (Younger and Adams, 1999). Mines that spill to the surface have generally at that time attained their fully-flooded, or equilibrium, pool elevation. This equilibrium pool elevation may fluctuate with seasonal variations in recharge (Pigati and Lopez, 1999; Light, 2001).

In flooding or flooded mines that are pumped to prevent spill discharges, pool elevations vary according to mine-water control strategies, but they are generally maintained below stream elevations at all times. They may vary seasonally in hydraulic head, in response to time-varying pumping rates or to the timing of vertical recharge and leakage to the mine. The maximum allowable pool elevation during pumping is commonly referred to as the "control elevation."

In fully-flooded mines, equilibrium pool elevations are generally controlled by surface discharge or pumping. However, many mines that are neither pumped nor discharge to the surface may also attain equilibrium pool levels, as a result of barrier leakage to adjacent mines (Light and Donovan, 2015). Such a leak serves as an induced discharge point. Thus, one mine may induce equilibrium in adjacent mines by providing a sink for that mine's water. In this way, it may be possible to control pool elevations in a suite of multiple, contiguous mines by pumping groundwater from a single mine within the suite.

\subsection{Purpose}

This chapter documents a semi-continuous complete flooding history for a suite of contiguous underground coal mines which closed and refilled with water over a period of approximately 40 
years. The analyzed dataset starts roughly 20 years after the earliest mine closure (in the 1960s) and extends until post-mining equilibrium in 2014. By that time, all of the mines had completed flooding, and their water levels had more or less stabilized. Such long-term datasets showing mines in differing stages of flooding, are rare in the literature. This unusual dataset offers the opportunity to see, in detail, how mines of this type refill with water.

The results provide insights that may help in the prediction of flooding rates, discharge locations, and mine inflow quantities in similar mines that close in the future. In addition, these results may shed light on fundamental questions about how flooding of contiguous mines proceeds, including:

- can the duration of mine flooding be predicted using pumping volumes from active operations, and

- what role does barrier leakage play in the duration of mine flooding.

The analysis follows an inverse approach, back-determining the sequence of critical hydrologic events influencing flooding history, based on water-level hydrographs, which form the principal evidence for flooding. The full dataset includes mine maps georeferenced to a single projection; water level histories for six mines, compiled from both industry and regulatory files as well as data from this study; and the history of pumping and mine-discharge events. We also developed a new method for estimating mine inflow rates given water level data, mining methods, and mine geometry. 


\subsection{Study area}

A series of contiguous closed underground mines were chosen for study including the Gateway, Pitt Gas, Mather, Dilworth, Clyde, and Vesta mines, all in the Pittsburgh coal bed of southwestern Pennsylvania (Figures 4.2 and 4.3). In this area, younger coals are surface-mined, but no other coal beds are mined underground. The Pittsburgh bed has been mined virtually continuously from its outcrop, near elevation $233 \mathrm{~m}$, to a subsurface elevation of $110 \mathrm{~m}$. Mines in the study area typically include small, older (pre-1920) workings, as well as considerably larger mines that employed high-extraction, room-and-pillar and longwall mining. The mines operated over various timeframes (Table 4.1), and all are currently (2015) believed to be at postflooding equilibrium and either discharging to the surface, leaking into adjacent mines, or managed by pumping.

The Pittsburgh coal is Pennsylvanian in age and marks the base of both the Monongahela Group and the Pittsburgh Formation, which is comprised of alternating layers of coal, sandstone, mudstone, shale, laminites, limestone, and siltstone. The Monongahela Group contains other younger coals (Sewickley, Waynesburg, and Washington units) lying 30-150 m above the Pittsburgh bed. The Monongahela is overlain by the Dunkard Group, comprised of similar sedimentary units (Edmunds et al., 1999). All strata are gently folded $\left(<5^{\circ}\right)$ and dip to the westnorthwest (Beardsley, et al., 1999). The axis of a minor fold, the Belle Vernon Anticline, lies within the study area and passes through several of these mines (Figure 4.3). The anticline topographically divides several of the mines into eastern and western sections. 


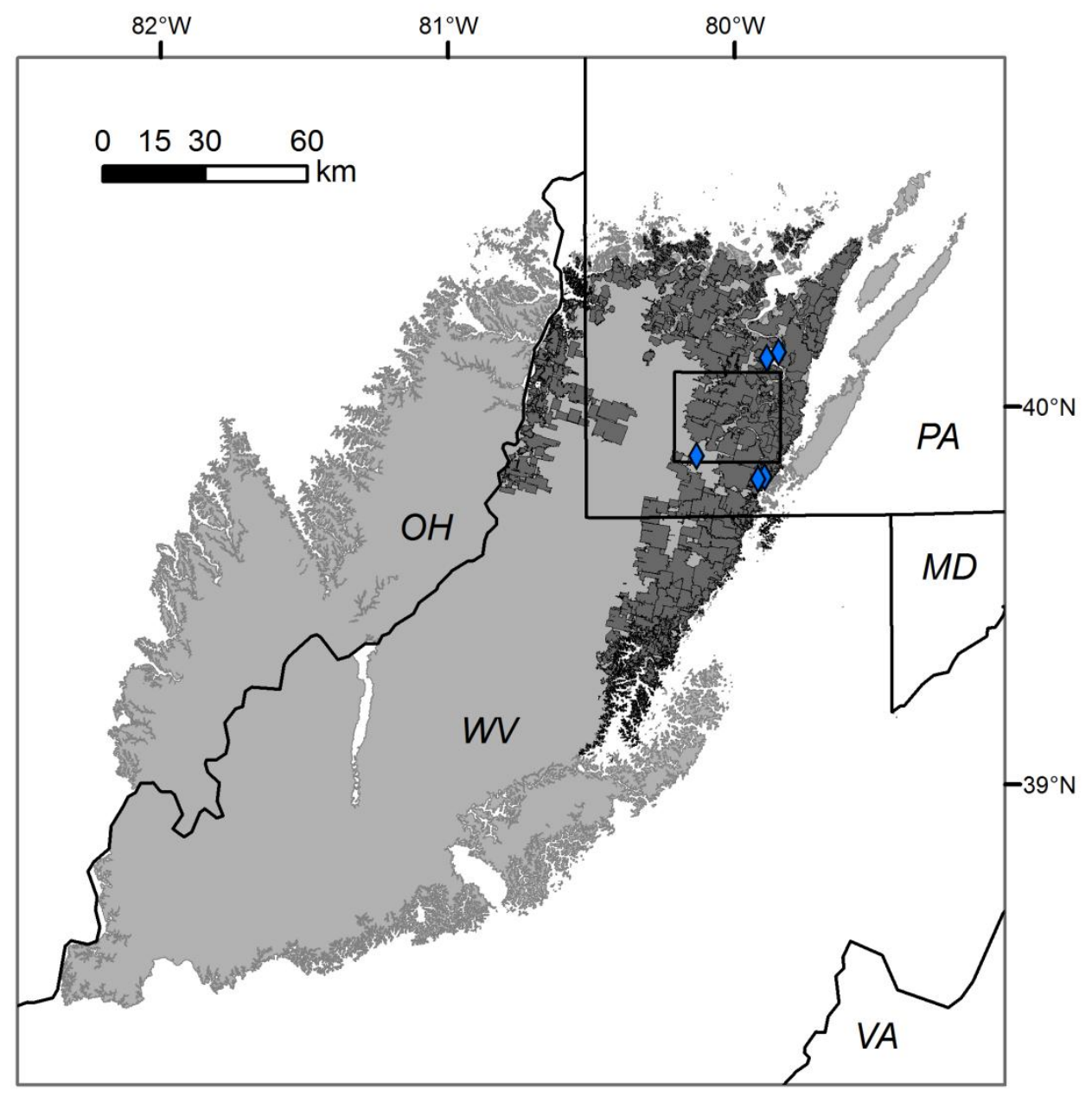

Figure 4.2. Extent of the Pittsburgh coal bed (light shading), areas of underground mines in the Pittsburgh bed (medium shading), weather stations (diamonds), and the study area (box). 


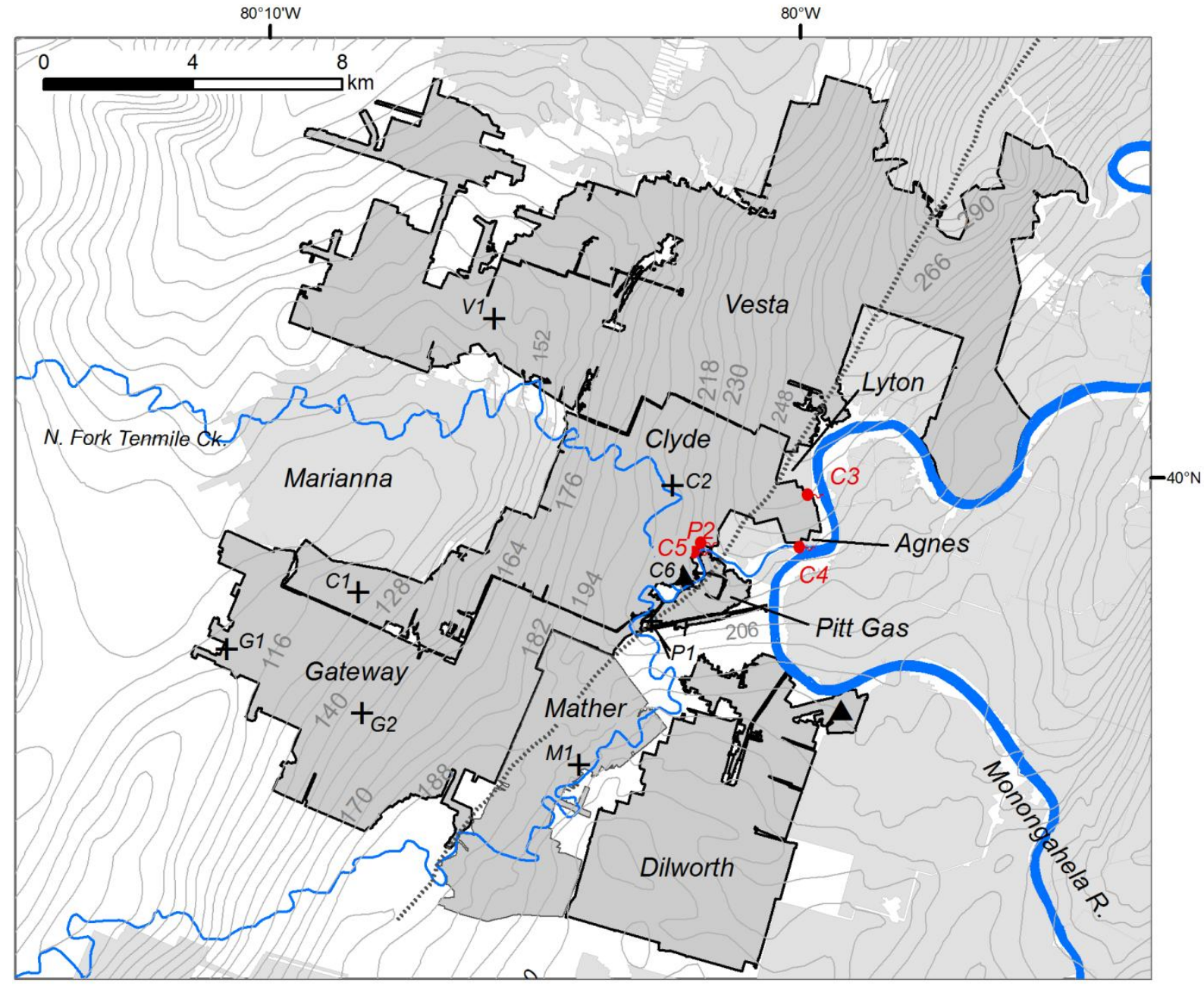

Figure 4.3. Underground Pittsburgh-seam mines (light shading), study mines (medium shading), the axis of the Belle Vernon Anticline (dotted line), monitoring wells (crosses), treatment plants (triangles), and surface discharges (red symbols). See text and Table 4.2 for descriptions; contour lines represent the base of the Pittsburgh coal, contour interval is approximately $6 \mathrm{~m}$. 
Table 4.1. Mine area, overburden statistics, and flooding dates

\begin{tabular}{lcccccccccc}
\multicolumn{1}{c}{ Mine } & Closed & $\begin{array}{c}\text { Area } \\
\left(10^{7} \mathrm{~m}^{2}\right)\end{array}$ & \multicolumn{2}{c}{ Overburden thk., $\mathrm{m}$} & \multicolumn{2}{c}{$\mathrm{A}_{90^{* *}}$} & \multicolumn{2}{c}{ Begin Flooding } & \multicolumn{2}{c}{ End Flooding } \\
& & & Mrn. & Avg. & $\left(10^{6} \mathrm{~m}^{2}\right)$ & Date & Elev., $\mathrm{m}$ & Date & Elev., $\mathrm{m}$ \\
\hline Clyde & 1988 & $4.0^{*}$ & 8 & 319 & 144 & 6.00 & 1984 & 122 & 1996 & 229 \\
Dilworth & 2004 & 3.4 & 36 & 283 & 177 & 0.41 & 2004 & 152 & 2007 & 226 \\
Gateway & 1990 & 4.1 & 31 & 309 & 192 & 0.37 & 1990 & 110 & 2013 & 235 \\
Mather & 1964 & 2.0 & 77 & 265 & 144 & 0.53 & 1964 & 158 & 2005 & 201 \\
Pitt Gas & 1990 & 0.2 & 8 & 153 & 85 & 1.30 & 2007 & 213 & 2013 & 236 \\
Vesta & 1986 & $11.0^{*}$ & $<3$ & 262 & 127 & 13.5 & $<1986$ & 134 & 1993 & 253 \\
\hline
\end{tabular}

*West of the axis of the Belle Vernon Anticline.

${ }^{* *}$ Area with overburden thickness $<90 \mathrm{~m}$. 
Groundwater movement within areas underlain by Pennsylvanian strata of the Allegheny Plateau has been described by Wyrick and Borchers (1981), Kipp and Dinger (1987), Stoner et al. (1987), Hobba (1991), and Harlow and LeCain (1993). Changes in hydrogeology induced by mining were observed by Singh and Kendorski (1981), Stoner (1983), Booth (1986), Aljoe and Hawkins (1992), Kendorski (1993), Williams et al. (1993), Winters and Capo (2004), and Light and Donovan (2015). Leavitt (1999) described the use of barrier pillars within Pittsburgh bed mines.

\subsection{Methodology}

To examine the flooding history of mines, mine-pool elevations, maps, and pumping and discharge information were compiled from several data sources. Mine-pool elevation histories were compiled from permit files at the Pennsylvania Department of Environmental Protection (PADEP), and others were measured continuously for this study in five monitoring wells during 1996-2015 (Figure 4.3; Table 4.2). Pumping data and considerable anecdotal information regarding mine operations as well as the timing, location, and estimated volume of mine discharges were similarly gleaned from PADEP permit files. Mine maps used in this study were scanned from PADEP files, digitized, and georectified (Donovan and Leavitt, 2004).

Surveyed wellhead measuring-point elevations, sensor depths, and groundwater-pressure heads from transducers were converted to water-level elevations in the five monitoring wells in the study area (Figure 4.3) for various periods (Table 4.2). Procedures for data collection and reduction are summarized by Leavitt et al. (2003). These water-level elevations, combined with the PADEP water-level data, produced complete or nearly-complete flooding hydrographs for 
Table 4.2. Monitoring well nomenclature, periods of record, and data sources

Table 4.2. Monitoring well nomenclature, periods of record, and data sources.

\begin{tabular}{ccccccc} 
Mine & PADEP CMAP \# & ID & Description & Location Name & Period & Source \\
\hline Clyde & 63891301 & C1 & moniting well & Ross Shaft & $1 / 1981-8 / 1997$ & PADEP \\
Clyde & 63891301 & C2 & moniting well & Hawkins Shaft & $1 / 2001-4 / 2010$ & HRC* \\
Clyde & 63891301 & C3 & surface discharge & Clyde \#1 portal & $1 / 1986-9 / 1996^{*}$ & PADEP \\
Clyde & 63891302 & C4 & surface discharge & Engle's Marina & $1954-$ present & PADEP \\
Clyde & 63891301 & C5 & surface discharge & Clyde \#2 slope & $5 / 2012-5 / 2013$ & \\
Clyde & 63971701 & C6 & moniting well & Treatment Plant & $1 / 2000-11 / 2014$ & PADEP \\
Gateway & 30841321 & G1 & moniting well & Ruff Creek RDBH & $10 / 1991-9 / 2000$ & PADEP \\
Gateway & 30841321 & G1 & moniting well & Ruff Creek RDBH & $9 / 2000-12 / 2014$ & HRC \\
Gateway & 30841321 & G2 & moniting well & Grimes RDBH & $9 / 2000-12 / 2014$ & HRC \\
Mather & 9100 & M1 & moniting well & Mather MW & $1 / 2001-9 / 2002$ & HRC \\
Pitt Gas & 3077302 & P1 & moniting well & Pitt Gas MW & $4-2004-12 / 2014$ & HRC \\
Pitt Gas & 3077302 & P2 & surface discharge & Tenmile Creek & $2 / 2014-8 / 2014$ & \\
Vesta & 63841304 & V1 & moniting well & Kefover Shaft & $12 / 1986-1 / 2012$ & PADEP \\
\hline
\end{tabular}

* HRC - West Virginia Water Research Institute Hydrology Research Center 
the Gateway, Pitt Gas, Clyde, and Vesta mines. No data were available for the earliest flooding in Clyde or Vesta, and a considerable data gap exists in the Clyde water-level record.

Permit-file pumping records for Gateway reported the average annual rate for pumping in both Gateway and the adjacent Pitt Gas mines. These records indicate that after 1985, all of the water that infiltrated into Pitt Gas drained through a series of horizontal pipes installed across the Pitt Gas-Gateway barrier, then was subsequently pumped from within Gateway. The Clyde file reported estimated pumping rates over time during active operations, a partial record of pumping at the Clyde mine water treatment plant that opened in 1999, and estimated flow rates for surface discharges at the \#1 Portal and Tenmile Creek which occurred during 1996-1997. The Vesta file lists only its maximum daily rate of pumping. No pumping data were reported in the Mather permit file, and the mine has flooded without pumpage or any surface discharge.

\subsection{Observed flooding history, 1980-2014}

\subsubsection{Vesta mine}

The PADEP permit file for Vesta indicates that several small discrete pools developed deep in the mine prior to closure in 1986 (Figure 4.4A). The mine flooding rate, as observed at a borehole in the Kefover pool, increased abruptly in 1987 (event 1, Figure 4.5), ascribed to the onset of spillage from saturated up-dip pools to the deeper Kefover pool. This pool rose rapidly at a relatively constant rate until 1991 (event 2, Figure 4.5), then slowed in flooding rate, interpreted as the result of increased barrier leakage into Clyde. Evidence for this includes mine 

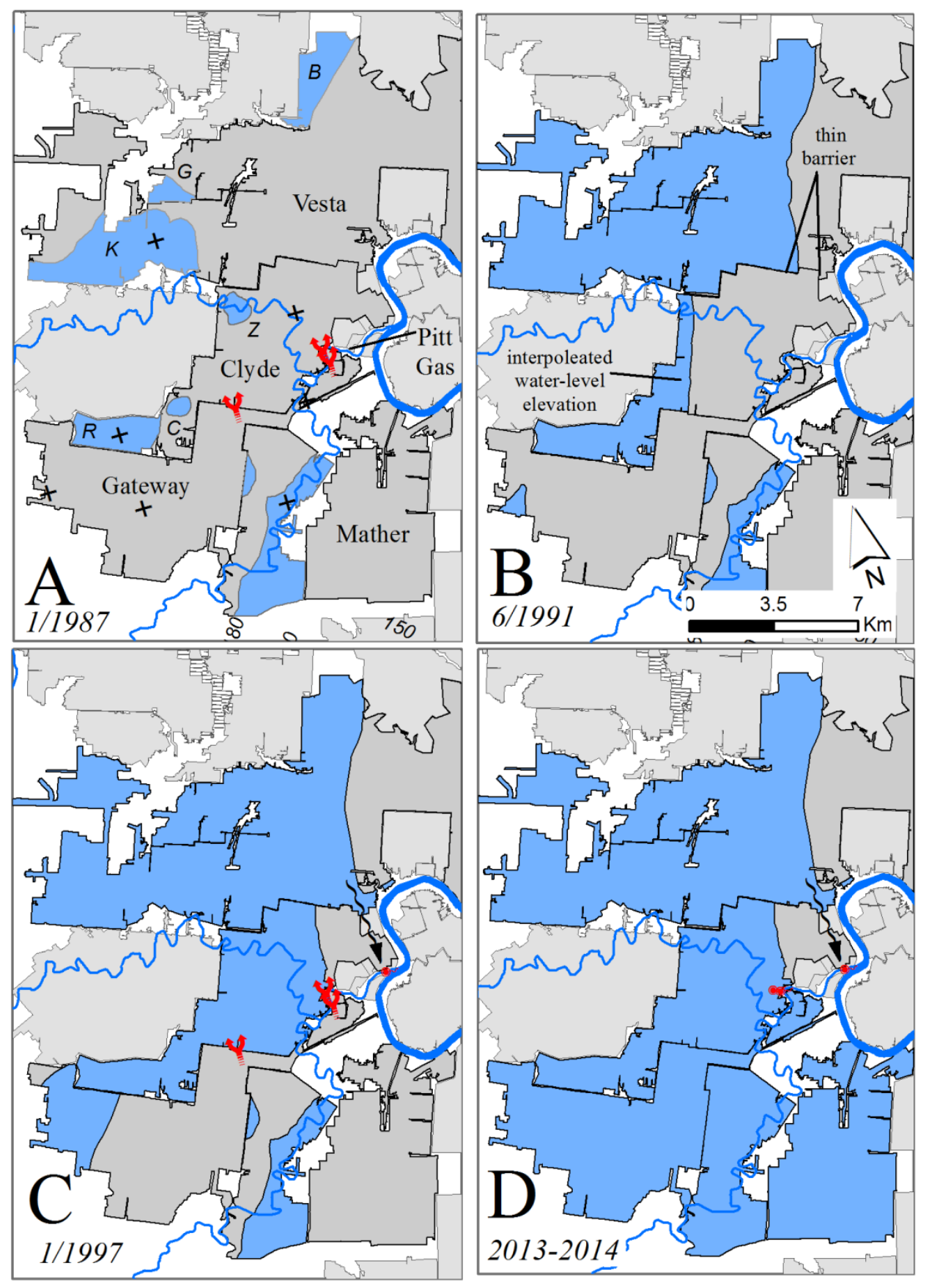

Figure 4.4. Development of flooding in study area mines (pool designations: $K=$ Kefover; $G$ $=$ Greenlee; $B=$ Berick; $R=$ Ross; $C=$ Clyde; $Z=$ Zollarsville). Also shown, crosscuts between Clyde and Gateway/Pitt Gas (red arrows), thin Vesta-Clyde barrier section, and inferred flow path for spillage from Vesta (black arrow). 


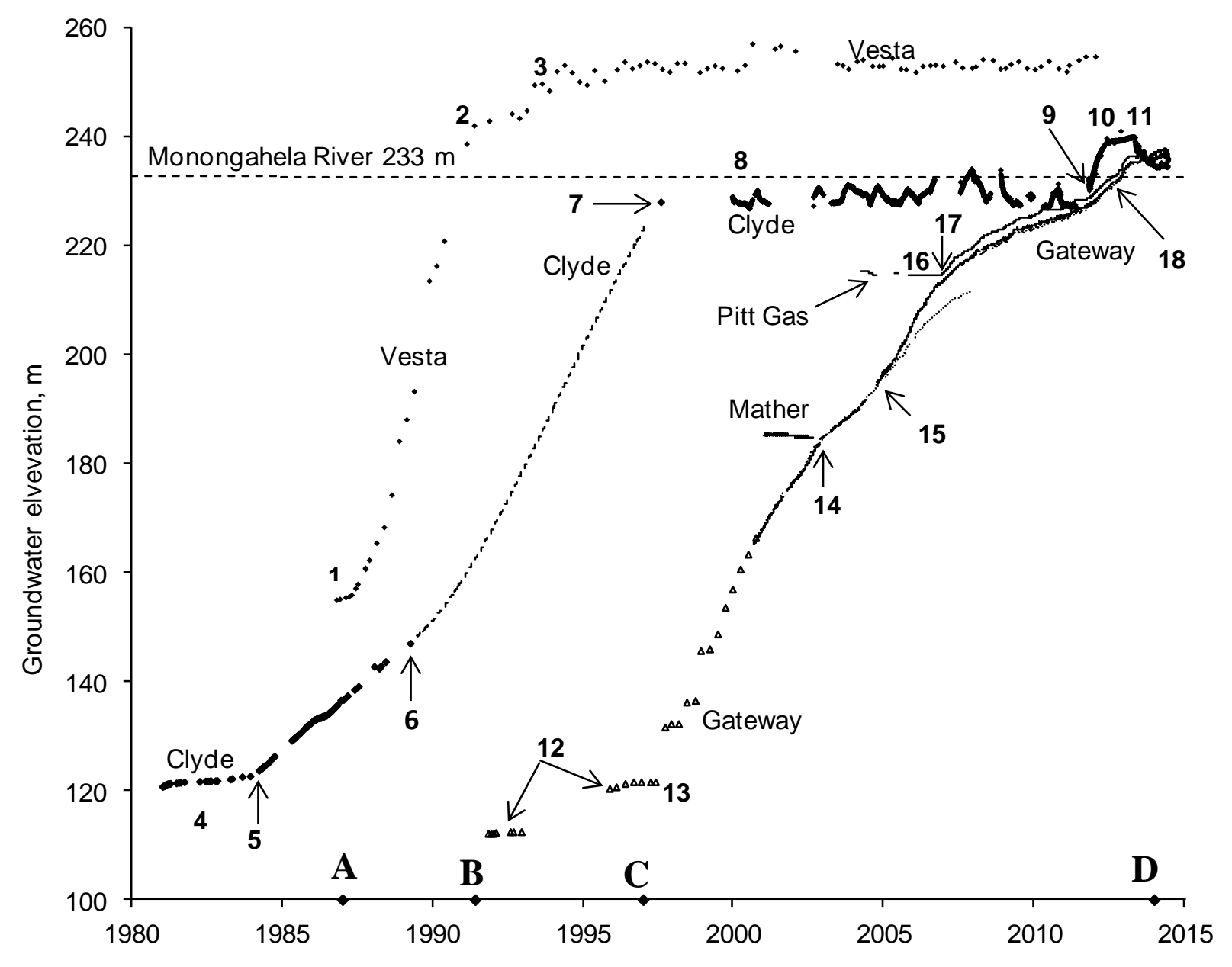

Figure 4.5. Mine-pool elevation hydrograph for wells in Vesta, Clyde, Mather, Pitt Gas, and Gateway mines. Bold letters indicate time periods shown in Figure 4.4. Numbers represent events discussed in the text. Dashed line indicates interpolated data. 
maps that show the Vesta-Clyde barrier to be $<3 \mathrm{~m}$ thick above elevation $240 \mathrm{~m}$. Decreased flooding may also reflect below-average precipitation and recharge during 1991 and 1992 (Figure 4.6). The flooding rate in the Kefover pool increased again in 1993 until it leveled off at an approximate elevation of $253 \mathrm{~m}$ in 1994 (event 3, Figure 4.5). Based on this elevation, we interpret this as the subsurface spill elevation at the crest of the Belle Vernon Anticline (Figures 4.3 and $4.4 \mathrm{C})$.

Following equilibration, minor fluctuations in pool level continued, which we interpret as the effect of seasonal variations in recharge. Mine maps and permit files indicate that water spilling over the anticline would have flowed down-dip into the Lyton mine, which was connected to Vesta by open entries, and thence into Clyde (Figure 4.4C). In the eastern section of Clyde, groundwater was diverted by an underground drain into the older Agnes mine (Figure 4.3), from which, it discharged to Tenmile Creek via a drain pipe installed prior to the 1954 closure of Agnes (discharge C4, Figures 4.3; and Figure 4.4C). Evidently, the diversion drain in Clyde became blocked at some time in 1995 or 1996, formed a backed up pool, and discharged from the Clyde \#1 portal (elevation 242 m) into the Monongahela River near Fredericktown, PA during spring 1996 (discharge C3, Figure 4.3). The discharge was estimated by PADEP at 40-45 L/s. The Clyde \#1 Portal was sealed by PADEP in late 1996, stopping the Fredericktown discharge and re-diverting flow into Agnes. In spring 1997, the C4 drain from Agnes to Tenmile Creek became blocked and ruptured, causing mine water to discharge to Tenmile Creek near a marina. The pipe was repaired by PADEP later in 1997, thus reestablishing the C4 discharge into Ten Mile Creek (Figure 4.4C). 


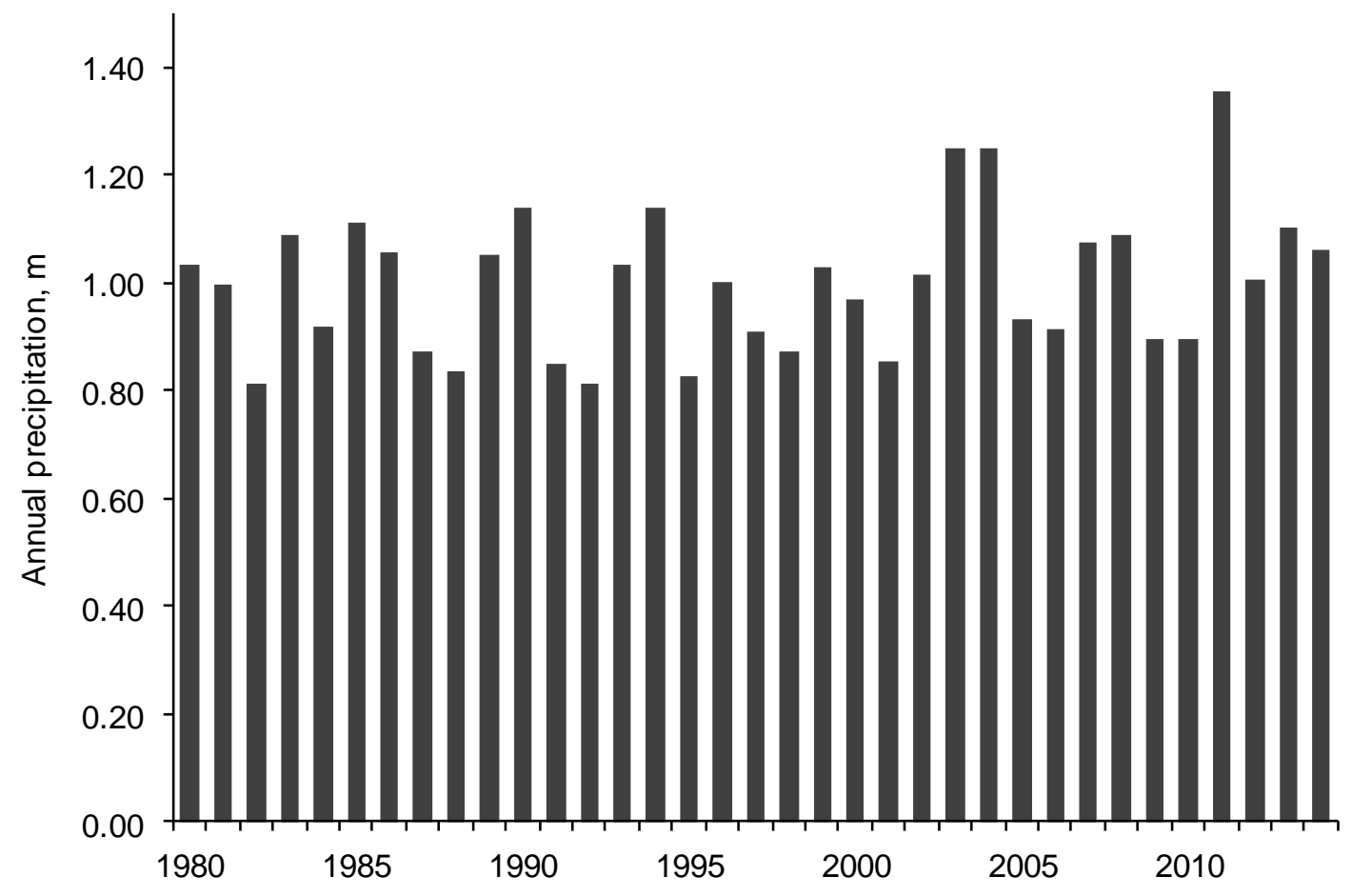

Figure 4.6. Average precipitation from five NCDC weather stations (Charleroi, USC00361377; Donora, USC00362190; Gray's Landing, USC00363451; Greensboro Lock and Dam, USC00363503; and Waynesburg USC00369367. See Figure 4.2 for locations. 
In summary, rapid post-closure flooding of Vesta mine caused $98 \mathrm{~m}$ of water level rise over a 7year period from 1986 to 1993 . This flooding applied high pressures on the Vesta-Clyde barrier and is believed to have increased barrier leakage into Clyde until this mine also filled and reduced the head difference across this barrier. The Vesta pool reached a spill elevation at the crest of the Belle Vernon anticline, overflowing into eastern Clyde via Lyton mine and influenced the later C3 and C4 discharges from Clyde, into the Monongahela River (Fredericktown) and Tenmile Creek (Clarksville marina), respectively. The Vesta pool still fluctuates due to seasonal variations in recharge, barrier leakage, and discharge rate to Tenmile Creek.

\subsubsection{Clyde mine}

Clyde maps and water-level data collected during active operations indicate that, following mining in the late 1960s but prior to 1981, a large pool developed in the vicinity of the Ross Shaft (Figure 4.4A; event 4, Figure 4.5). In 1984, the mine operator stopped pumping to the surface and began diverting all mine-water inflows to the Ross pool, abruptly increasing its flooding rate (event 5, Figure 4.5). Clyde pool elevations interpolated from sparse readings between 4/1989 and 8/1997 (events 6 and 7, Figure 4.5) clearly, but imprecisely, indicate a water level increase of $81 \mathrm{~m}$ between these dates. This increase is partially attributed to a high rate of barrier leakage from Vesta, whose pool elevation ranged from 27 to $76 \mathrm{~m}$ higher than that of Clyde over this period.

Pumping to control the rising western pool of Clyde began on 6/8/1999 at PADEP's new Clyde mine-water treatment plant (location C6, Figure 4.3). For the next 12 years, the Clyde pool was 
maintained by pumping at a control elevation of $230 \mathrm{~m}$ (event 8, Figure 4.5) until 11/14/2011 when failure of a sludge-injection well caused the plant to shut down (event 9, Figure 4.5). From this date, the Clyde pool rose above the surface elevation of its \#2 portal $(236 \mathrm{~m})$, resulting in a spill discharge, (discharge C5, Figure 4.3), which began on 8/6/2012 (event 10, Figure 4.5). Pumping resumed on 5/23/2013, lowering the pool elevation (event 11, Figures 4.5 and 4.7) and terminating the surface discharge.

\subsubsection{Gateway and Pitt Gas mines}

Early post-closure water levels in Gateway (event 12, Figure 4.5) indicate slow initial flooding, followed by a rapid increase in rate starting in 1997 (event 13, Figure 4.5). This is ascribed this to an increase in barrier leakage due to large head difference with respect to the rapidly-filling Clyde pool. The Gateway pool elevation rose steadily until 2003 (event 14, Figure 4.5), when its flooding level reached the Mather barrier at elevation $186 \mathrm{~m}$ (Figure 4.3), then slowed abruptly. This is interpreted as the onset of barrier leakage from Gateway into Mather, which had been hitherto unflooded. Flooding in Gateway accelerated again in 2004 (event 15, Figure 4.5), suggesting that flooding had completed filling Mather, reducing the barrier leakage rate from Gateway.

P1, the Pitt Gas monitoring well (Figure 4.3) showed a nearly constant water level prior to 2007 at $215 \mathrm{~m}$, the elevation of the Pitt Gas-Gateway drains (event 16, Figure 4.5). This is interpreted as the result of spill drainage from Pitt Gas into Gateway, whose pool elevation was far below the drain location. Then starting in 2007, the Pitt Gas pool began rising concurrently with the Gateway pool (event 17, Figure 4.5), indicating a reduction or reversal of flow through the drains 


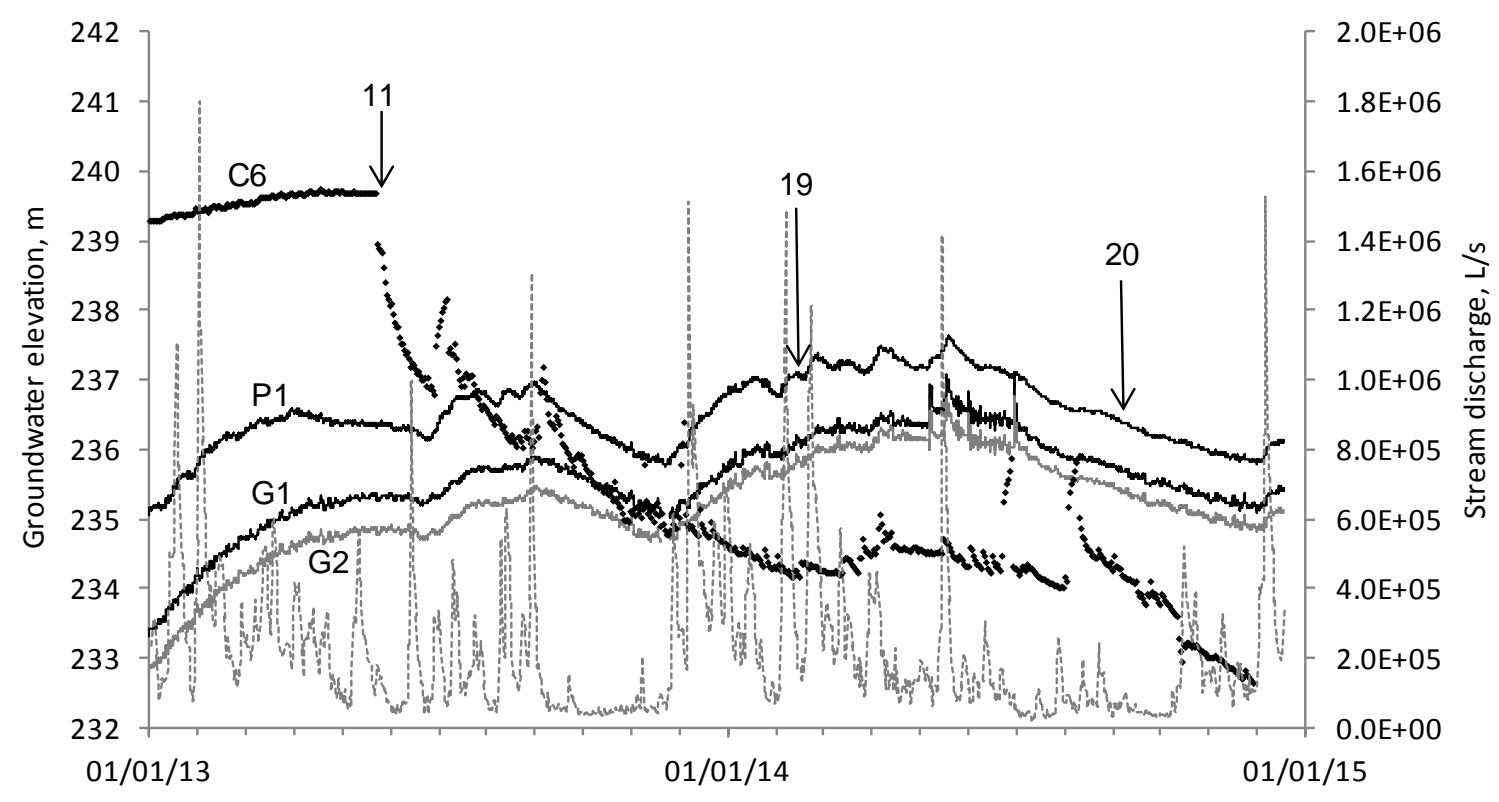

Figure 4.7. Recent (2013-2014) mine pool elevations for Clyde (C6), Gateway (G1, G2), and Pitt Gas (P1) mines. Dashed line is discharge in the Monongahela River. See Table 2 and text for description of annotation. 
between Pitt Gas and Gateway. Thereafter, the Gateway and Pitt gas pools fluctuated in unison, albeit with a slight decline in head from wells P1 to G1 to G2. This decline gradually narrowed from $2.1 \mathrm{~m}$ in 2007 to $0.8 \mathrm{~m}$ in 2014. In 2012, flooding again accelerated in the merged pool, and is attribute to a reduction in the amount of unfilled pore space, as the mine water in Pitt Gas "roofed" (event 18, Figure 4.3).

In February 2014, after Pitt Gas pool had attained a water level approximately $4.3 \mathrm{~m}$ above Tenmile Creek, a discharge was reported and confirmed on the mid-stream bed of the creek (K. Dufalla, personal communication; discharge P2, Figure 4.3). The onset of this discharge is indicated on a detailed hydrograph of the Gateway, Clyde, and Pitt Gas boreholes (event 19, Figure 4.7). Mine maps indicate this discharge location corresponds to that of a crosscut tunnel connecting Pitt Gas and Clyde at elevation $223 \mathrm{~m}$ (Figure 4.4A and C), roughly six m below streambed. The discharge was small $(<10 \mathrm{~L} / \mathrm{s})$, but visually evident due to red iron precipitates, and appeared to originate from a single location on the creek bed. The discharge was no longer detectable in September 2014, when the pool elevation dropped below $236.5 \mathrm{~m}$, still $3.5 \mathrm{~m}$ above the creek level (event 20, Figure 4.7). Recent (2014) abrupt pool fluctuations in Pitt Gas indicate that precipitation events (Figure 4.7) induce recharge from shallow aquifers.

During the 2014 period of this discharge (2/14 to 9/14), the water level in Clyde ranged from 1.7 to $2.1 \mathrm{~m}$ above creek level. This was approximately $4.6 \mathrm{~m}$ below its $2011-2013$ elevation when Clyde spilled at the \#2 portal across Tenmile Creek from Pitt Gas. The 2014 mid-stream discharge into Tenmile Creek was not observed while Clyde was discharging at this time and elevation, and hence the source of the 2014 Tenmile Creek breakout is ascribed to the Gateway- 
Pitt Gas pool, not Clyde. Based on these observations, the mine-water discharge into Tenmile Creek in 2014 is attributed to upward leakage from the Pitt Gas-Gateway pool through a tight fracture in the roof of the Pitt Gas-Clyde crosscut tunnel. The leakage was driven by $4.0-4.3 \mathrm{~m}$ of pressure head, but leakage ceased once the pressure head dropped below $3.5 \mathrm{~m}$.

\subsubsection{Mather and Dilworth mines}

A limited amount of water level data for the Mather mine shows that the mine was partially flooded for decades after closure until 2003. This is inferred to have been related to leakage across the Mather-Dilworth and the Mather-Gateway barriers, which are separated by the crest of an anticline. (Table 4.1, Figures 4.3, 4.4 and 4.5; Light and Donovan, 2015). Mine water is thought to have leaked from Gateway to Mather beginning in 2003 when the Gateway pool reached the barrier separating these mines, interpreted from a plateau in the Gateway hydrograph at this elevation (event 14, Figure 4.5), although no water levels are available from Mather for this period. Dilworth closed in 2004 and flooded to a control elevation of $217 \mathrm{~m}$ by 2007, after which barrier leakage from Mather into Dilworth would have been greatly reduced. It is inferred that, currently (2015), leakage flows from Gateway to Mather and thereby to Dilworth, as evidenced by seasonally-declining summer hydraulic head in Gateway since 2007. There are no mines with sufficiently low pool elevations to accept leakage from Gateway except Mather and Dilworth. Modeling results examining this scenario are presented in Light and Donovan (2015).

\subsubsection{Discussion}

Mine flooding proceeded sequentially in this series of 4 mines, starting with Vesta, the earliest to close; then Clyde; then Gateway; and finally Pitt Gas, the last to close. This sequential flooding 
was controlled, in part, by the timing of closures and, in part, by changes in barrier-flow conditions between adjacent mines. Water-level hydrographs in Vesta, Clyde, Gateway, and Pitt Gas illustrate temporal changes in barrier leakage and spillage between these mines (Figure 4.5).

Flooding hydrographs for all three pools (Vesta, Clyde, and Gateway-Pitt Gas) are sigmoidal in shape, showing slow initial flooding, followed by accelerated flooding, and finally by a reduction in flooding rate prior to re-equilibration. Initial increased flooding rates in both Vesta and Clyde stem from cessation of pumping during active operations, while the later increase in the Clyde pool level is attributed to barrier inflow from Vesta.

This increase in leakage rate is interpreted to have occurred when the Vesta pool attained higher elevations of 240-250 m, where the Vesta-Clyde barrier is especially thin. Similarly, accelerated flooding in Gateway is interpreted to have been caused by an increase in barrier leakage from Clyde. Flooding in Clyde was stopped by pumping at the Clyde treatment plant, while flooding in Gateway slowed due to reduction of barrier leakage from Clyde and vertical infiltration into Pitt Gas as the pool in that mine filled to a high level.

The pool level in Clyde was at a lower elevation than the pool in Gateway/Pitt Gas during 2014 indicating the potential for barrier leakage from Gateway/Pitt Gas into Clyde. However, fluctuations in the Clyde pool level caused by pumping in 2014 showed little or no influence on water levels in Gateway/Pitt Gas (Figure 4.7). This combined with the apparent seasonality of pool levels in Gateway/Pitt Gas indicate that barrier leakage to Mather is the most significant water loss causing this pool to stabilize. 
In summary, pool levels in each of the mines stabilized by different mechanisms. Flooding in Vesta was slowed by barrier leakage to Clyde and later stopped completely due to spillage over the Belle Vernon Anticline. The Clyde pool level was stabilized by pumping starting in 1999. The Gateway/Pitt Gas pool appears to have stabilized since 2013 by a combination of discharge to Tenmile Creek and barrier leakage to adjacent mines (either Clyde or Mather, or both, depending on transient head conditions).

\subsection{Mine porosity and flooding-duration models}

Flooding occurred much more quickly than predicted in Vesta, Clyde, and Gateway/Pitt Gas. In 1988, PADEP used historic pumping rates and estimated pore volumes to conclude that 41 years would be required for the Clyde pool to reach the elevation of the \#2 portal (236 m) near the Clyde treatment plant (location C6, Figure 4.3). Actual, recorded water levels indicate that the pool reached this elevation in June 1999, after only 11 years (Figure 4.5).

Similarly, flooding rates do not appear to correlate with or be controlled by mine geometry and slope. Under constant inflow, flooding rates should show correlation with mine width and dip slope in the vicinity of the mine pool surface. For example, between elevations 165 and $207 \mathrm{~m}$, Clyde significantly increases in width, and mine maps indicate that uniform mining methods were employed in this area; therefore, the flooding rate should have decreased. However, the Clyde hydrograph indicates an acceleration in flooding across this elevation interval (Figures 4.3 and 4.5). These observations imply that using simple assumptions to predict mine flooding timeframes will produce estimates that are substantially in error and suggest that some additional 
factor or factors besides simple mine geometry and constant inflow rates are controlling the flooding timeframe in these mines.

The hydrographic record clearly indicates that rates of flooding vary over time within the four mines, and that barrier leakage between mines plays a major role in the sequence of and ultimate equilibration after flooding. To evaluate these effects, the flooding process was modeled using two different techniques. The simplest model of mine flooding is to assume that inflow to the mine is time-uniform and similar to the rate of pumping during active operations, and to ignore the effects of barrier leakage between adjacent mines. Under these assumptions, the flooding rate depends only on the inflow rate, the hypsometric distribution of porosity in the mine, and the geometry of the mine, e.g. the dip of the mine floor and the width of the mine at the leading edge of the flooding pool. Models of this type were developed by Younger and Adams (1999).

\subsubsection{Hypsometric model of pore volume}

The spatial distribution of porosity within Vesta, Clyde, Gateway, and Pitt Gas mines was estimated using georectified mine maps and interpolated structure contours of the coal bottom elevation. Mined areas in Vesta, Clyde, and Gateway/Pitt Gas were mapped and digitized according to mining type: longwall (LW), high-extraction room-and-pillar (HE), room-and-pillar (RP), main entries (M), and pillars (P; i.e. no extraction) (Figure 4.8). The residual post-mining

pore volume for each mining type was estimated assuming an average Pittsburgh-bed coal thickness of $2.0 \mathrm{~m}$ (Edmunds et al., 1999) and industry rule-of-thumb extraction ratios (LW = $100 \%, \mathrm{HE}=80 \%, \mathrm{RP}=50 \%, \mathrm{M}=30 \%$; Hartman and Mutmansky, 2002). Large coal pillars were estimated to have a porosity of 0.003 (Hobba, 1991). 


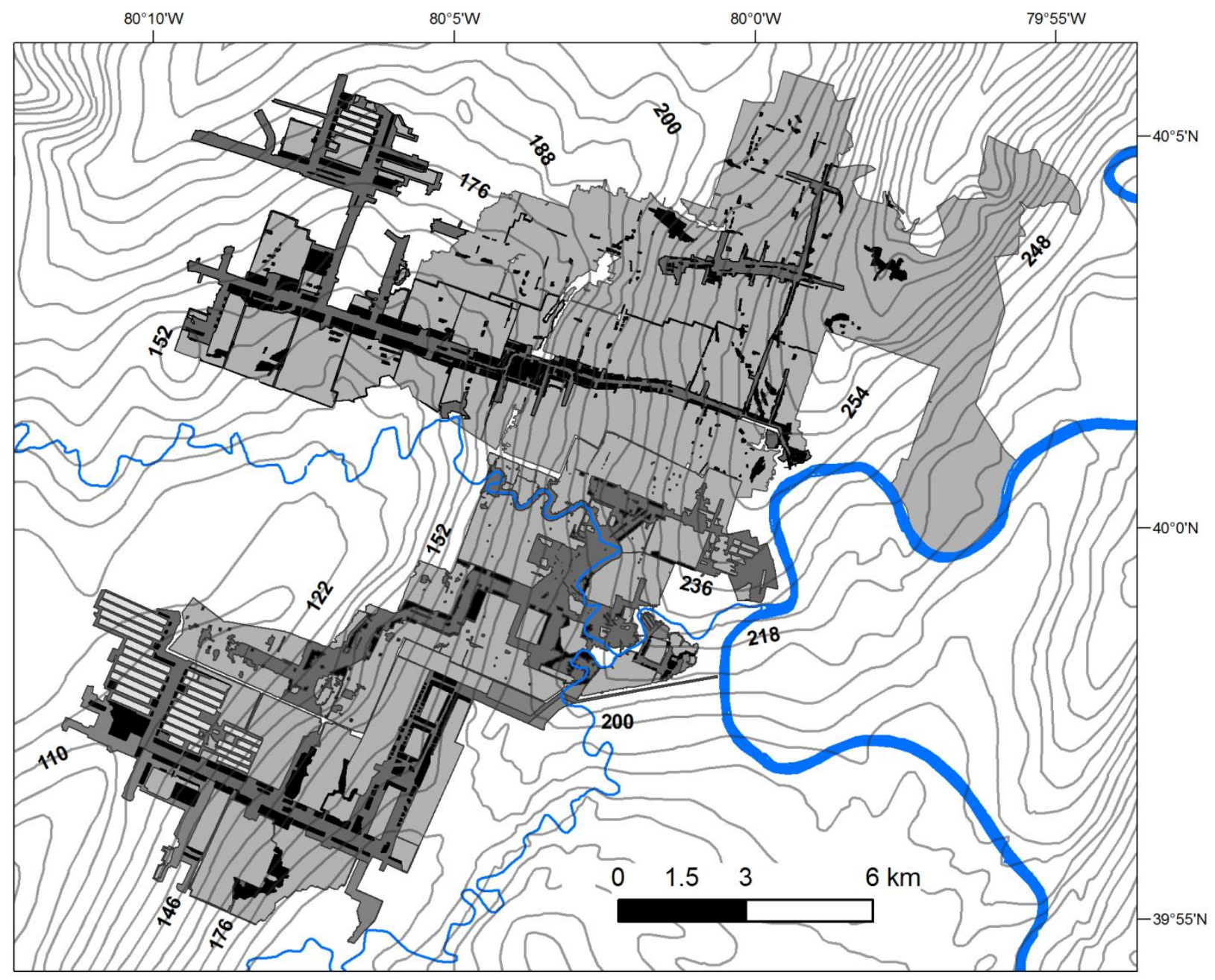

Figure 4.8. Mapped mining type area polygons for Vesta, Clyde, Gateway, and Pitt Gas mines $(10 \%$ shading $=\mathrm{LW} ; 30 \%=\mathrm{HE} ; 50 \%=\mathrm{RP} ; 70 \%=\mathrm{M} ; 100 \%=\mathrm{P})$. Contour interval is six m. 
Each mine was subdivided into spatial intervals between contour lines to determine the hypsometric distribution of average porosity and pore volume. Areas within each interval were estimated for each mining type by intersecting contour-interval polygons with mining-type polygons (Figure 4.8). The porosity within each hypsometric interval is:

$$
\phi_{\mathrm{i}}=\frac{1}{\hat{\mathrm{A}}_{\mathrm{i}}} \sum_{\mathrm{j}=1}^{\mathrm{m}} \varphi_{\mathrm{j}} \mathrm{A}_{\mathrm{ij}}
$$

where $\phi_{\mathrm{i}}=$ spatial-average porosity within the ith hypsometric interval [1]

$$
\begin{aligned}
& \mathrm{m}=\text { mining types }(=5), \\
& \varphi_{\mathrm{i}}=\text { porosity of the } \mathrm{jth} \text { mining type }[1], \\
& \mathrm{A}_{\mathrm{ij}}=\text { area of the jth mining type within the ith hypsometric interval }\left[\mathrm{L}^{2}\right] \text {, and } \\
& \hat{\mathrm{A}}_{\mathrm{i}}=\text { area of the ith hypsometric interval }\left[\mathrm{L}^{2}\right] .
\end{aligned}
$$

Pore volume $\mathrm{V}_{\mathrm{i}}$ within each hypsometric interval is:

$$
\mathrm{V}_{\mathrm{i}}=\mathrm{h}_{\mathrm{i}} \phi_{\mathrm{i}} \mathrm{bW} \mathrm{W}_{\mathrm{i}} \cot \theta_{\mathrm{i}}
$$

where

$h_{i}=$ hypsometric interval [L] (i.e. the contour interval or height over which $V_{i}$ is estimated)

$$
\begin{aligned}
& \mathrm{b}=\text { coal thickness }[\mathrm{L}] \\
& \mathrm{W}_{\mathrm{i}}=\text { average width of hypsometric interval i }[\mathrm{L}] \\
& \theta_{\mathrm{i}}=\text { average dip angle within hypsometric interval i [1]. }
\end{aligned}
$$


Figure 4.9 shows contour intervals and cumulative $V_{i}$ distribution for each mine (Table 4.3).

Roughly $25 \%$ of the pore volume in the Gateway and Pitt Gas mines is associated with longwall panels in the deepest part of Gateway, while $<2.5 \%$ is contained in the room-and-pillar workings of the much smaller Pitt Gas mine (Figures 4.3 and 4.8). Approximately $90 \%$ of the pore volume in the western section of Clyde is filled at its control elevation of $230 \mathrm{~m}$, while $80 \%$ of the pore volume in Vesta is fully-flooded at its spill elevation of $253 \mathrm{~m}$ (Figure 4.4D).

\subsubsection{Flooding duration and rate models}

A hypsometric pore-volume model was used to evaluate flooding in Clyde and Gateway/Pitt Gas. Active-operation pumping rates (Table 4.4) were employed as a time-constant inflow rate, because, during active operations, the surrounding mines were also active and either dry or minimally-flooded so barrier leakage was very low or absent. The rate of flooding $\mathrm{dh} /\left.\mathrm{dt}\right|_{\mathrm{i}}$ associated with this constant-rate inflow $\mathrm{Q}_{\mathrm{AC}}\left[\mathrm{L}^{3} / \mathrm{t}\right]$ is:

$$
\left.\frac{\mathrm{dh}}{\mathrm{dt}}\right|_{\mathrm{i}}=\frac{\tan \theta_{\mathrm{i}}}{\mathrm{b} \mathrm{W}_{\mathrm{i}} \varphi_{\mathrm{i}}} Q_{\mathrm{AC}}
$$

Under these assumptions, Clyde would at constant inflow have required 24 years to flood to its surface-discharge elevation (239 m; Figure 4.10A). Similarly, the Gateway/Pitt Gas mines would have required 56 years to fill to the $232 \mathrm{~m}$ elevation of the mine roof in Pitt Gas, also the approximate Tenmile Creek elevation (Figure 4.10B). However, both mines actually flooded in far shorter times than this, suggesting that actual inflow rates were, on average, far greater than the active-operation pumping rates (Table 4.4). 


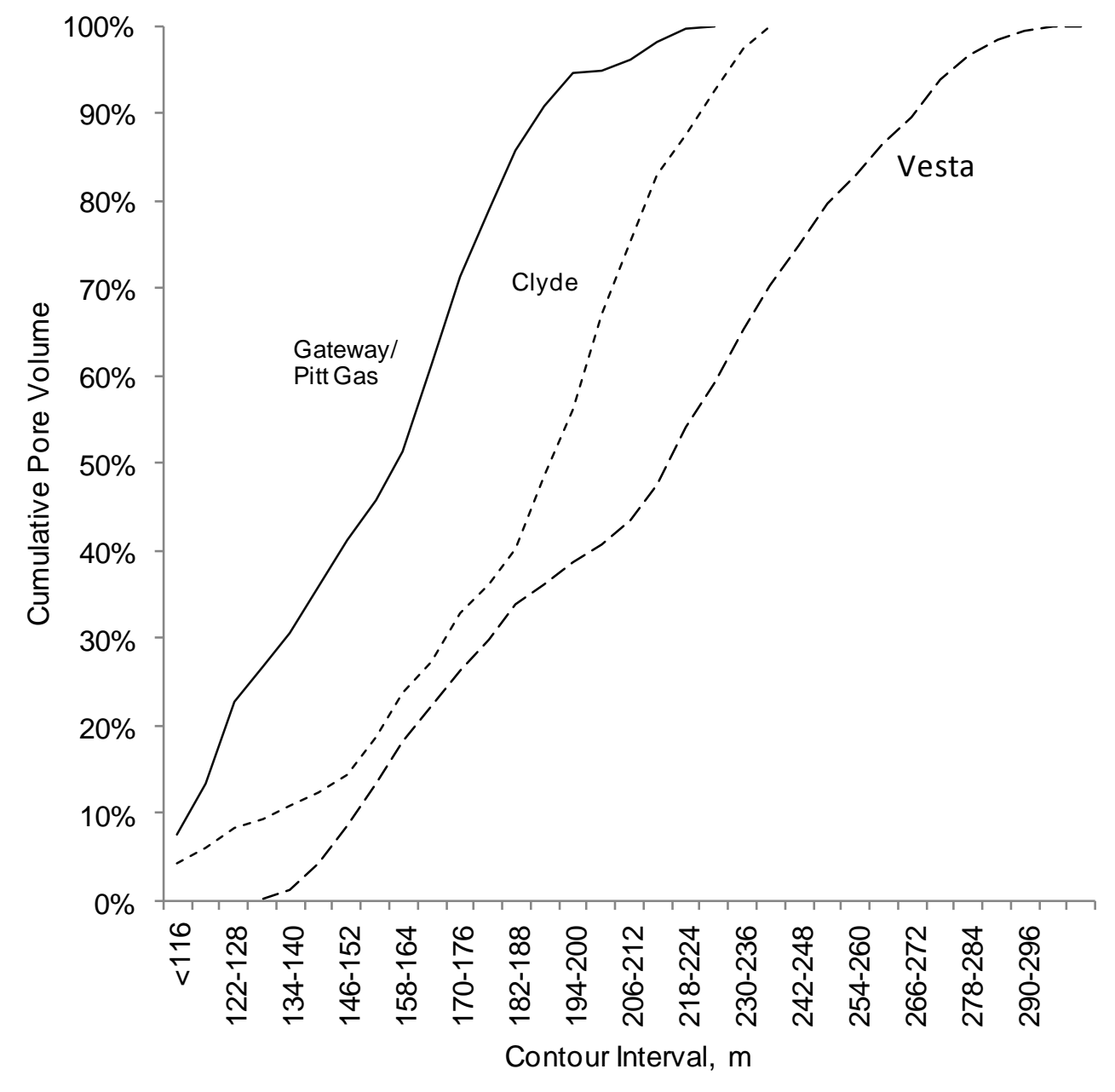

Figure 4.9. Cumulative pore volume distribution by contour interval in Vesta, Clyde, and Gateway/Pitt Gas mines. Contours intervals are in meters. 
Table 4.3. Estimated total pore volumes for Clyde, Gateway/Pitt Gas, and Vesta mines

\begin{tabular}{lc} 
Mine & Estimated pore volume $\left(\mathrm{m}^{3} \times 10^{7}\right)$ \\
\hline Clyde & $3.82^{*}$ \\
Gateway/Pitt Gas & 4.22 \\
Vesta & $9.77^{*}$ \\
\hline
\end{tabular}

Table 4.4. Reported active-operation pumping rates

\begin{tabular}{lccc} 
Mine & Years & Rate (L/s) & Source \\
\hline Clyde & ?-1986 & $44(\mathrm{E})^{*}$ & PADEP \\
Gateway/Pitt Gas & $1981-1987$ & 21 & GCC \\
\hline${ }^{*}$ Area west of Belle Vernon Anticline & \\
$(1 \mathrm{gpm}=0.06 \mathrm{~L} / \mathrm{s})$ & & &
\end{tabular}



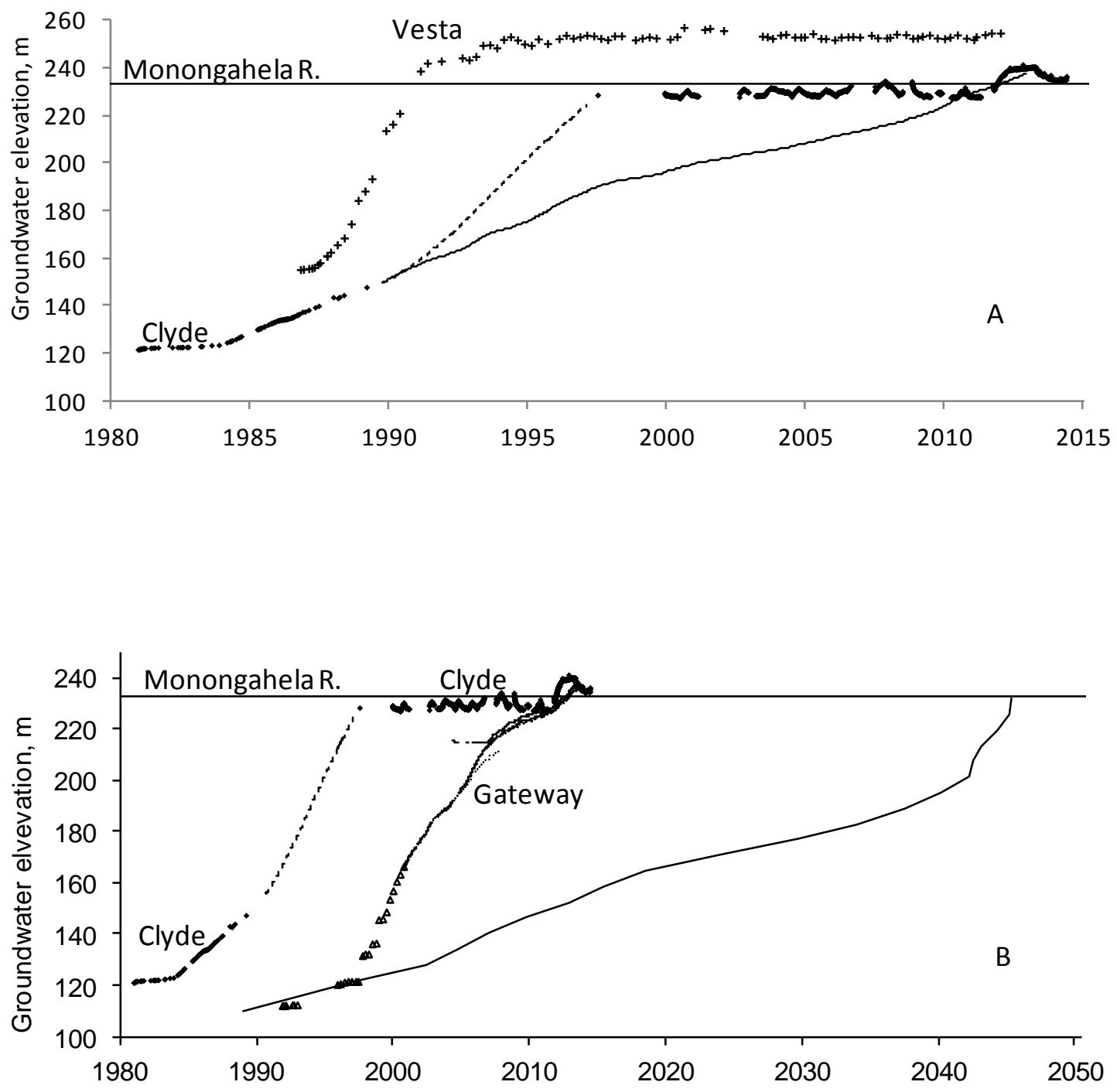

Figure 4.10. Predicted mine pool elevations (solid lines) for Clyde (A) and Gateway/Pitt Gas (B) assuming constant inflow rates. 
The changes in flooding rates observed in Vesta, Clyde, and Gateway/Pitt Gas strongly suggest transient barrier leakage rates between these mines. This violates the assumption of timeconstant $\mathrm{Q}_{\mathrm{AC}}$ used in the hypsometric model. Therefore, another modeled flooding rate was calculated using observed hydrograph flooding rates $(\mathrm{dh} / \mathrm{dt})$ and hypsometric porosity distributions to estimate inflow rates:

$$
\mathrm{Q}_{\mathrm{AV}}=\left.\frac{\mathrm{bW} \varphi_{\mathrm{i}}}{\tan \theta_{\mathrm{i}}} \frac{\mathrm{dh}}{\mathrm{dt}}\right|_{\mathrm{i}}
$$

where $\mathrm{Q}_{\mathrm{AV}}=$ variable rate inflow $\left[\mathrm{L}^{3} / \mathrm{t}\right]$ and other variables are as above.

Estimated inflow rates for Vesta, Clyde, and Gateway/Pitt Gas using this relationship (Figure 4.11) suggests that maximum inflow rates at each mine occurred at different times and in a specific sequence (first Vesta, then Clyde, then Gateway/Pitt Gas). The 1987 increase in Vesta inflow corresponds to mine closure and the cessation of pumping, while the decrease that begins in 1990 coincides with increasing barrier leakage from Vesta to Clyde, perhaps augmented by lower than average precipitation in 1991 and 1992 (Figure 4.11). The Clyde inflow-rate hydrograph shows a similar decrease corresponding to increased barrier leakage to Gateway (Figure 4.11). Decreases in the modeled Gateway/Pitt Gas inflow after 2000 are attributed to barrier leakage into Mather when the Gateway pool reached this barrier, as well as gradual reduction in barrier leakage from Clyde as the gateway Pool rose (Figure 4.11). Inflow to Vesta, Clyde, and Gateway/Pitt Gas is also likely to have been reduced by declining head gradients between surficial aquifers and mine pools.

It is difficult to estimate inflow rates after mine pools reach reequilibration levels, yet fluctuations in pool levels indicate that inflow still occurs. The location and elevation of the 

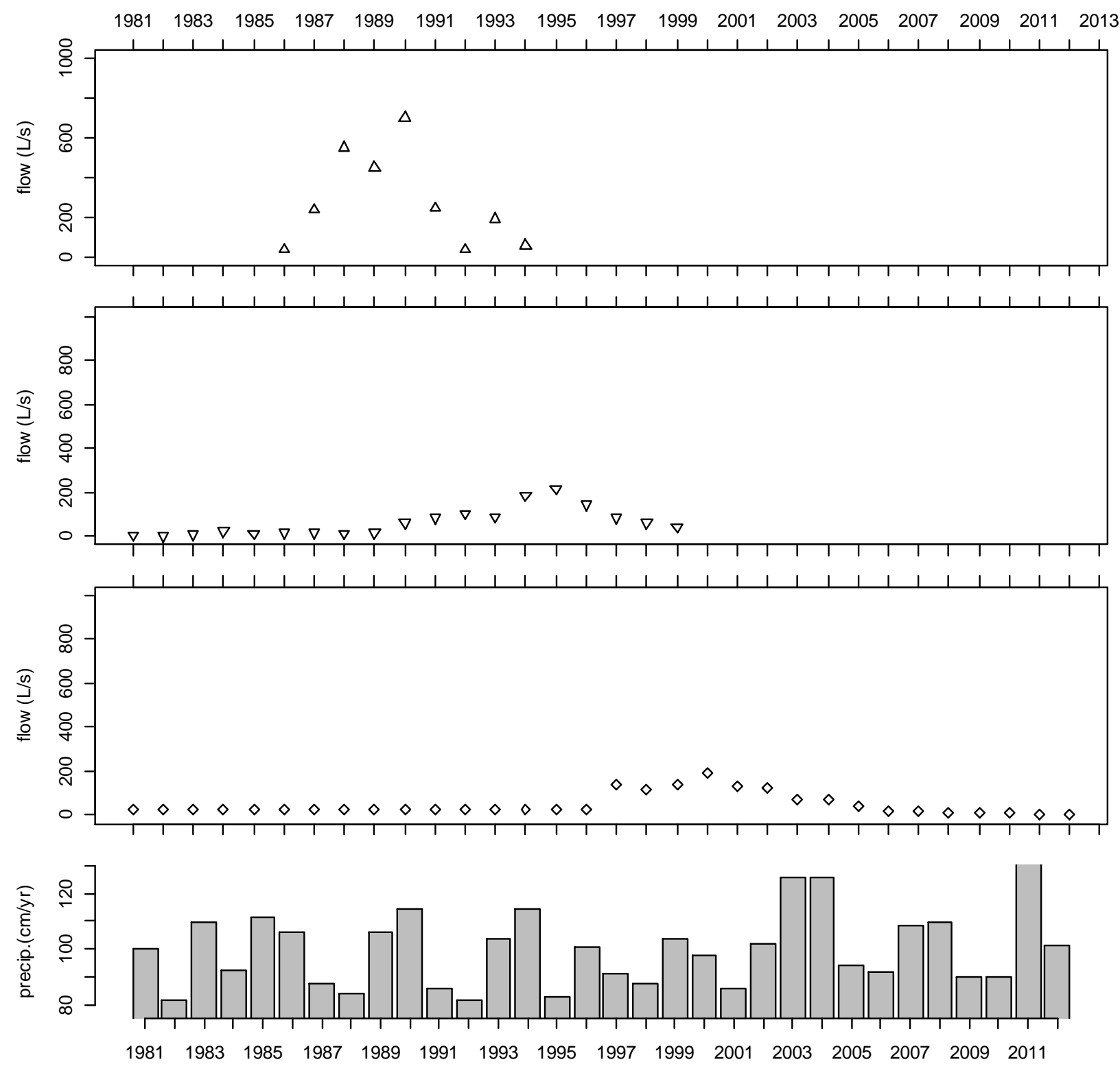

Figure 4.11. Estimated mine inflow rates for Vesta, Clyde, and Gateway/Pitt Gas mines; and average annual precipitation. 
mine pools relative to the most productive recharge areas (overburden thickness $<75 \mathrm{~m}$ similarly suggest continuing vertical infiltration inflow, especially in Vesta and Clyde (Figure 4.12). Sources of potential error in the estimated flooding and mine inflow rates include:

- uncertainty in mining type on the original mine maps,

- uncertainty in the actual volume of coal removed within each mining type area, and

- failure to consider reductions in mine pore volume due to subsidence or floor heave.

There is also some uncertainty associated with the interpolated water levels in Clyde that are due to sparse data. The interpolated water levels may not accurately reflect the timing of changes in flooding within the mine.

\subsection{Chapter Conclusions}

Pool elevations for a group of 5 adjacent contiguous underground below-drainage Pittsburgh bed mines were collected and compared to infer the history of flooding events influencing these mines between 1980 and 2015 (35 years). Pore volumes created by mining were estimated for three of these mines by digitizing areas by mining method and assuming uniform coal thickness of $2.0 \mathrm{~m}$. Hypsometric distributions of porosity were developed using coal-bottom elevation contours, and these were applied to estimate the duration of flooding assuming constant inflow equal to active-operation pumping rates. As an alternative to this constant-inflow estimate, empirical time-variable mine inflow rates during flooding were estimated from the hypsometric porosity distribution and mine pool elevation data.

Key conclusions that may be drawn from the water-level histories of these mines are: 


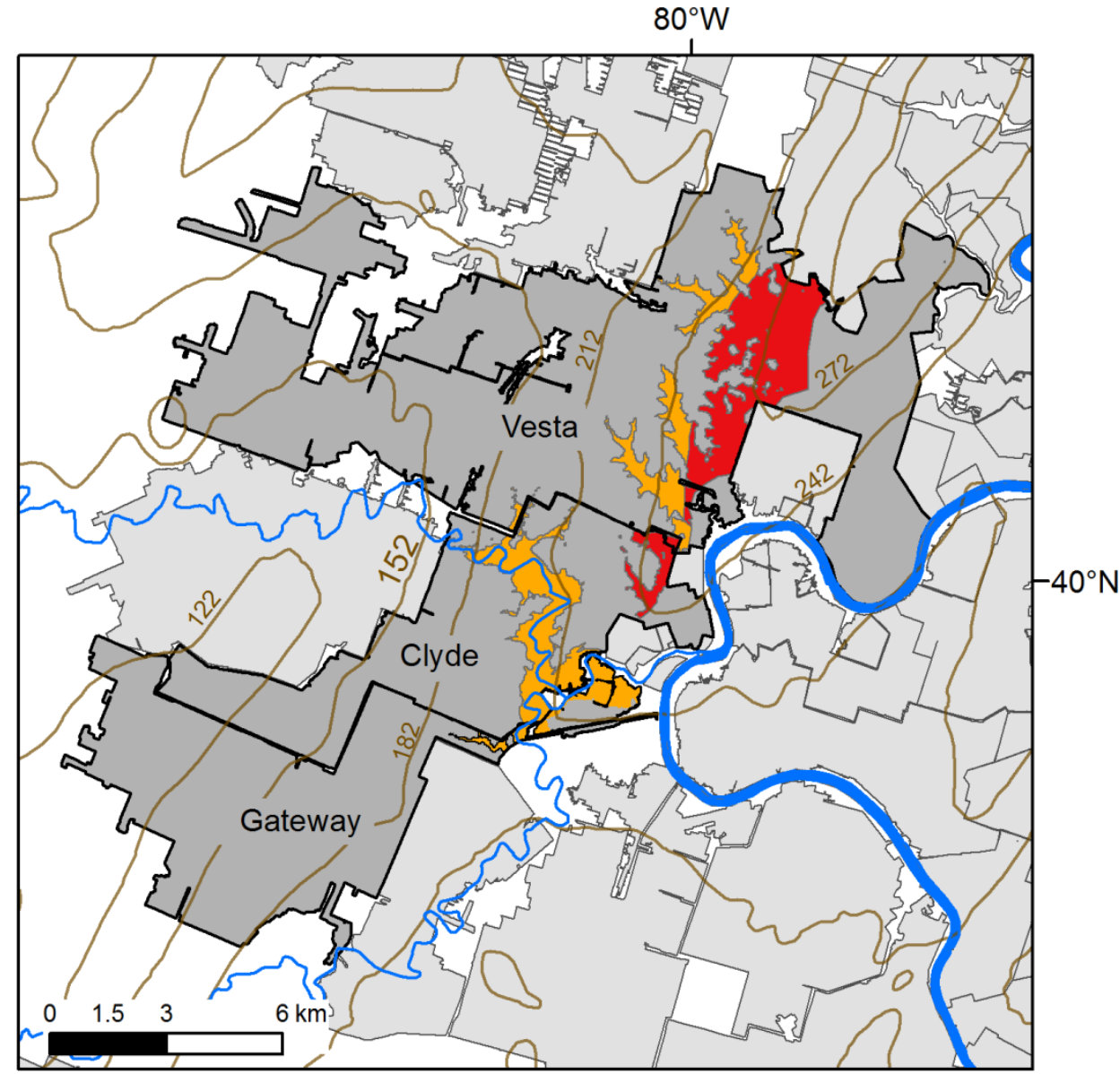

Figure 4.12. Mined areas with overburden thickness less than $75 \mathrm{~m}$ thick (orange and red) in Vesta, Clyde, Gateway, and Pitt Gas mines. The mine floor is up-dip from the mine pool in the red highlighted areas hence head-dependent inflows will be at a maximum in these areas. In areas where the mine floor is below the pool elevation (orange) and the distance between surficial aquifers and the pool surface has decreased, head-dependent inflows will be reduced by the depth of flooding. 
- Mine-pool-elevation hydrographs are typically sigmoidal, with slow initial flooding followed by a period of accelerated flooding and finally a decrease in filling rate prior to reequilibration of water levels.

- Inflection points observed in the flooding curves are thought to represent either coalescence of pools within a single mine, changes in inflow rate caused by barrier leakage (either into or out of a mine), or spillage into adjacent mines, through open barrier sections or, as in Vesta, at crests of anticlines. All of these events represent time variations in the water budget of one or more mines.

- The sequence of flooding in a group of adjacent mines is determined largely by closure order, with a similar rate of flooding in each mine. That is, the first mines to close are generally the first to complete flooding, all other factors equal.

- Mine-pool reequilibration was affected by different mechanisms in these three mines, including spillage to adjacent mines, spillage to the surface, pumping, and barrier leakage. The specific mechanism for equilibration in each mine was determined by barrier conditions, head differences between mines, geometry and openings in shallow workings, and, of course, whether or not intervention by pumping was performed.

- The terminal phase of flooding in two of these mines (Vesta and Pitt Gas/Gateway) appears to show significant slowing of the rapid intermediate inflow rates. It is proposed that this deceleration is related both to barrier leakage to neighboring mines with lower groundwater-head values and to lower vertical infiltration rates caused by gradient 
reduction between shallow overlying aquifers and the mine pool(s). Thus, the net inflow rates observed in the mine during intermediate flooding may be much larger than the net inflow rates observed at re-equilibration. The latter is the rate of inflow that must either be pumped and treated or will discharge to the surface.

All these observations underscore the fact that, to understand and/or predict flooding within a mine adjacent to others that are flooded or flooding, it is necessary to consider concurrent flooding in all neighboring mines and the influence each may have on its neighbors' mine inflow and/or outflow rates. Even in this case, there is some degree of unpredictability related primarily to uncertainty in the degree of hydraulic integrity of perimeter barriers between mines.

Pool elevations in adjacent mines are interdependent and controlled by the location and elevation of groundwater control points such as inter-mine barriers, spill points, and pumps. Thin or compromised barriers can accelerate flooding in adjacent mines, especially when inter-mine head differences are large. Spill points and pumping can stabilize pool levels in mine complexes by discharging water to the surface equal in amount to the net inflow rate -- that is, the sum of vertical infiltration and net barrier leakage.

Hypsometric porosity distributions under constant inflow have been used by others to estimate the duration of flooding (Younger and Adams, 1997). These estimates tend to underpredict the duration of flooding, because they do no account for head-dependent reductions in inflow as the mine pool approaches the surface (Whitworth, 2002). In contrast, this constant-inflow technique significantly overpredicted the duration of flooding for mines in this study. The difference 
between the two outcomes is attributed to barrier leakage associated with the close proximity of contiguous adjacent mines.

Results of this study indicate that accurate prediction of the duration of mine flooding requires explicit consideration of groundwater conditions in adjacent mines. Leaky coal barriers and internal spill points can cause groups of adjacent mines to flood as an interconnected cohort. In such a cohort of mines, a small number of pumping wells or discharge points may be sufficient to equilibrate pool levels in multiple mines, with some mines having no apparent groundwater control mechanism except for barrier leakage. 


\subsection{Chapter References}

Adams, R. and Younger, P. L., 2001, A strategy for modeling ground water rebound in abandoned deep mine systems: Groundwater, Vol. 39, No. 2, pp. 249-261.

Aljoe, W. W. and Hawkins, J. W., 1992, Application of aquifer testing in surface and underground mines: Groundwater Management, Vol. 13, pp. 541-555.

Banks, D.; Younger, P. L.; Arnesen, R.; Iversen, E. R.; and Banks, S. B., 1997, Mine-water chemistry: the good, the bad and the ugly: Environmental Geology, Vol. 32, No. 3, pp. 157174.

Banks, D., 2001, A variable-volume, head-dependent mine water filling model: Groundwater, Vol. 39, No.3, pp. 362-365.

Beardsley, R. W.; Campbell, R. C.; and Shaw, M. A., 1999, Chapter 20 Appalachian Plateaus, In C. H. Shultz (Editor), The Geology of Pennsylvania: Pennsylvania Geological Survey, Harrisburg and Pittsburgh Geological Survey, Pittsburgh, PA, 888 p.

Booth, C. J., 1986, Strata-movement concepts and the hydrogeological impact of underground coal mining: Groundwater, Vol. 24, No. 4, pp. 507-515.

Burke, S. P., and Younger, P. L., 2000, Groundwater rebound in the South Yorkshire coalfield: a first approximation using the GRAM model: Quarterly Journal of Engineering Geology and Hydrogeology, Vol. 33, No. 2, pp. 149-160. 
Donovan, J. J. and Leavitt, B.R., 2004, The future of mine-water discharges from underground coal mines of the Pittsburgh coal basin, WV-PA. In Richard I. Barnhisel, Editor. Proceedings of a Joint Conference of American Society of Mining and Reclamation 21st Annual National Conference and 25th West Virginia Surface Mine Drainage Task Force Symposium, Morgantown, WV p. 518-528.

Dufalla, K., 2015, personal communication, Izaak Walton League of Greene County, Pennsylvania.

Edmunds, W. E.; Skema, V. W.; and Flint, N. K., 1999, Chapter 10 Pennsylvanian, In C. H. Shultz (Editor), The Geology of Pennsylvania: Pennsylvania Geological Survey, Harrisburg and Pittsburgh Geological Survey, Pittsburgh, PA, 888 p.

Fenneman, N. M., 1938, Physiography of eastern United States, McGraw-Hill, New York, NY, 714 p.

Harlow, G. E., Jr. and Lecain, G. D., 1993, Hydraulic Characteristics of, and Groundwater Flow in, Coal Bearing Rocks of Southwestern Virginia: U.S. Geological Survey Water Supply Report 2388, 36 p.

Hartman, H. L. and Mutmansky, J. M., 2002, Introductory Mining Engineering, John Wiley \& Sons, New York, NY, 570 p.

Hennen, R. V. and Reger, D. B., 1913, Marion, Monongalia, and Taylor Counties: West Virginia Geological and Economic Survey, Morgantown, WV, 844 p. 
Hobba, W. A., 1991, Relation of Fracture Systems to Transmissivity of Coal and Overburden Aquifers in Preston County, West Virginia: U.S. Geological Survey Water-Resources Investigations Report 89-4137, 24 p.

Kendorski, F. S., 1993, Effect of high-extraction coal mining on surface and ground waters. In Proceedings, 12th International Conference on Ground Control in Mining, West Virginia University, Morgantown, WV, pp. 412-425.

Kipp, J. A. and Dinger, J. S., 1987, Stress-relief facture control of ground-water movements in the Appalachian Plateaus. Presented at the NWWA Focus Conference on Eastern Regional Ground-water Issues, July 1987, Burlington, VT, 6 p.

Leavitt, B. R., 1999, Mine flooding and barrier pillar hydrology in the Pittsburgh basin. In Proceedings 16th Annual International Pittsburgh Coal Conference, Pittsburgh, PA.

Leavitt, B. R., Donovan, J. J., Morris, A. J., and Werner, E., 2003, Modeling of mine flooding in the Pittsburgh Coal Basin, USA. 6th ICARD, Cairns, Australia, July 2003, p. 1065-1071

Light, D. D. M., 2001, A Hydrogeological and Hydrogeochemical Characterization of the Truetown Mine Discharge: M.S. Thesis, Ohio University, Athens, OH, 271 p.

Light, D. D. M., and Donovan, J. J., 2015, Mine-water flow between contiguous underground coal mines with hydraulically compromised barriers: Environmental \& Engineering Geoscience, Vol. 21, No. 2, pp. 147-164. 
McCoy, K. J.; Donovan, J. J.; and Leavitt, B. R., 2006, Horizontal hydraulic conductivity estimates for intact coal barriers between closed underground mines: Environmental \& Engineering Geoscience, Vol. 12, No. 3, pp. 273-282.

Pigati, E. and Lopez, D. L., 1999, Effect of subsidence on recharge at abandoned mines generating acidic drainage: the Majestic Mine, Athens County, $\mathrm{OH}$ : Mine Water and the Environment, Vol. 18, No. 1, pp. 45-66.

Singh, M. M. and Kendorski, F. S., 1981, Strata disturbance prediction for mining beneath surface water and waste impoundments. In Proceedings of the 1st Conference on Ground Control in Mining: West Virginia University, Morgantown, WV, pp. 76-89.

Stoertz, M. W.; Hughes, M. L.; Wanner, N. S.; and Farley, M. E., 2001, Long-term water quality trends at a sealed, partially flooded underground mine. Environmental \& Engineering Geoscience, Vol. 12, No. 1, pp. 51-65.

Stoner, J. D., 1983, Probable hydrologic effects of subsurface mining: Groundwater Monitoring Review, Vol. 3, No. 1, pp 128-137.

Stoner, J. D.; Williams, D. R.; Buckwalter, T. K.; Felbinger, J. K.; and Pattison, K. L., 1987, Water Resources and the Effects of Coal Mining, Greene County, Pennsylvania, Water Resource Report 63, Pennsylvanian Geological Survey, 4th Series, 166 p.

Williams, D. R.; Felbinger, J. K.; and Squillace, P. J., 1993, Water Resources and the Hydrologic Effects of Coal Mining in Washington County, Pennsylvania, U.S. Geological Survey Open File Report 89-620, 
Whitworth, K. R., 2002, The monitoring and modeling of mine water recovery in UK coalfields. In Younger, P. L., and Robins, N. S. (Editors), Mine Water Hydrogeology and Geochemistry. Geological Society of London Special Publication 198, London, UK, pp. $61-73$

Winters, R. W., and Capo, R. C., 2004, Ground water flow parameterization of an Appalachian coal mine complex. Groundwater, Vol. 42, No. 5, pp. 700-710.

Wyrick, G. G., and Borchers, J. W., 1981, Hydrologic Effects of Stress-Relief Fracturing in an Appalachian Valley, U.S. Geological Survey Water-Supply Paper 2177, 51 p.

Younger, P. L. and Adams, R., 1999, Predicting mine water rebound. Environment Agency R\&D Technical Report W179. Bristol, United Kingdom 


\section{SUMMARY}

Objectives for study included:

i. estimation of mine recharge and barrier leakage rates using barrier geometry, pumping records, and observed water-level data; and

ii. evaluation of mine flooding chronologies using mine-pool hydrographs and estimated mine porosity and inflow rates.

Mine recharge and barrier-leakage rate estimates were evaluated using flow modeling under approximate steady-state conditions, calibrated using observed water-level and pumping data (Chapter 3). Pumping rates from active operations were applied to hypsometric models of mine porosity and compared to observed water-level data, and transient mine-inflow rates were estimated using the porosity models and observed water-level data (Chapter 4).

Results of this study indicate that underground mines in the Pittsburgh coal may form hydraulically interconnected complexes and that the head and leakage relationships between pools may vary during both flooding and reequilibration. These hydraulic interconnections may be maintained by leaky barriers, boreholes, and vertical fractures between different mined beds; their existence may be detected on water-level hydrographs as breaks in slope. In some cases, the degree of interconnection may allow pumping from a single mine to serve as the predominant groundwater sink for a group of adjacent mines, from which no surface discharge is observed. This has implications for not only the capacity and location of mine-water treatment plants, but also long-term treatment costs. 
The duration of flooding may be predicted using inflow rates during active operations and hypsometric distributions of mine porosity. This method usually provides a minimum-duration estimate due to reductions in inflow that result from decreasing head differences between mine pools and source aquifers. However, this method has been shown to overpredict the duration of flooding for mines in the Pittsburgh coal. This discrepancy is attributed to barrier leakage to adjacent mines greatly accelerating flooding. Uncertainty in barrier conditions between adjacent mines makes the accurate prediction of the duration of flooding problematic. An initial flooding-duration estimate can be made using active-operation pumping rates and mine maps with the expectation that the actual duration of flooding will be longer. Yet, continual monitoring of mine pool elevations is essential for refinement of the flooding duration estimate and characterization of barrier conditions between adjacent mines. 


\section{DISSERTATION REFERENCES}

Adams, R. and Younger, P. L., 2001, A strategy for modeling ground water rebound in abandoned deep mine systems: Groundwater, Vol. 39, No. 2, pp. 249-261.

Aljoe, W. W. and Hawkins, J. W., 1992, Application of aquifer testing in surface and underground mines: Groundwater Management, Vol. 13, pp. 541-555.

Banks, D.; Younger, P. L.; Arnesen, R.; Iversen, E. R.; and Banks, S. B., 1997, Mine-water chemistry: the good, the bad and the ugly: Environmental Geology, Vol. 32, No. 3, pp. $157-174$.

Banks, D., 2001, A variable-volume, head-dependent mine water filling model: Groundwater, Vol. 39, No. 3, pp. 362-365.

Beardsley, R. W.; Campbell, R. C.; and Shaw, M. A., 1999, Chapter 20 Appalachian Plateaus, In C. H. Shultz (Editor), The Geology of Pennsylvania: Pennsylvania Geological Survey, Harrisburg and Pittsburgh Geological Survey, Pittsburgh, PA, 888 p.

Becher, A. E., 1971, Ground water in Pennsylvania: Pennsylvania Geological Survey, Harrisburg, PA, 42 p.

Booth, C. J., 1986, Strata-movement concepts and the hydrogeological impact of underground coal mining: Groundwater, Vol. 24, No. 4, pp. 507-515.

Bruhn, R. W., 1986, Influence of deep mining on the groundwater tegime at a mine in Northern Appalachia, In S. S. Peng (Editor) Proceedings of the 2nd Workshop on Surface 
Subsidence due to Underground Mining: West Virginia University, Morgantown, WV, pp. 234-238.

Burke, S. P., and Younger, P. L., 2000, Groundwater rebound in the South Yorkshire coalfield: a first approximation using the GRAM model: Quarterly Journal of Engineering Geology and Hydrogeology, Vol. 33, No. 2, pp. 149-160.

Callaghan, T., Fleeger, G., Barnes, S., and Dalberto, A., 1998, Chapter 2 Groundwater flow on the Appalachian Plateau of Pennsylvania, In Brady, K. B. C., Smith, M. W., Schueck, J. (Editors), Coal Mine Drainage Prediction and Pollution Prevention in Pennsylvania: Pennsylvania Department of Environmental Protection, Harrisburg, PA, pp. 2.1-2.39.

Cross, A. T., 1954, The Geology of the Pittsburgh Coal: West Virginia Geological and Economic Survey, Morgantown, WV: $80 \mathrm{p}$.

Donovan, J. J. and Fletcher, J., 1999, Hydrogeological and Geochemical Response to Mine Flooding in the Pittsburgh Coal Basin, Southern Monongahela River Basin: Project WV132, Report to the U. S. Environmental Protection Agency, 47 p.

Donovan, J.J.; Leavitt, B. R.; and Werner, E., 2003, Long-term changes in water chemistry as a result of mine flooding of the Pittsburgh coal basin, USA, 6th ICARD, Cairns, Australia, July 2003, pp. 869-875.

Donovan, J. J. and Leavitt, B. R., 2004, The future of mine-water discharges from underground coal mines of the Pittsburgh coal basin, WV-PA. In Richard I. Barnhisel, Editor. Proceedings of a Joint Conference of American Society of Mining and Reclamation 21st 
Annual National Conference and 25th West Virginia Surface Mine Drainage Task Force Symposium, Morgantown, WV p. 518-528.

Dufalla, K., 2015, personal communication, Izaak Walton League of Greene County, Pennsylvania.

Edmunds, W. E.; Skema, V. W.; and Flint, N. K., 1999, Chapter 10 Pennsylvanian, In C. H. Shultz (Editor), The Geology of Pennsylvania: Pennsylvania Geological Survey, Harrisburg and Pittsburgh Geological Survey, Pittsburgh, PA, 888 p.

Fenneman, N. M., 1938, Physiography of eastern United States, McGraw-Hill, New York, NY, $714 \mathrm{p}$.

Harbaugh, A. W.; Banta, E. R.; Hill, M. C.; and McDonald, M. G., 2000, The U. S. Geological Survey modular ground-water model -- user guide to modularization concepts and the ground-water flow process: U.S. Geological Survey Open-File Report 00-92, 121 p.

Harlow, G. E., Jr. and Lecain, G. D., 1993, Hydraulic Characteristics of, and Groundwater Flow in, Coal Bearing Rocks of Southwestern Virginia: U.S. Geological Survey Water Supply Report 2388, 36 p.

Hartman, H. L. and Mutmansky, J. M., 2002, Introductory Mining Engineering, John Wiley \& Sons, New York, NY, 570 p.

Hawkins, J. W. and Dunn, M., 2007, Hydrologic characteristics of a 35-year-old underground mine pool: Mine Water and the Environment, Vol. 26, No. 3, pp. 150-159. 
Hennen, R. V. and Reger, D. B., 1913, Marion, Monongalia, and Taylor Counties: West Virginia Geological and Economic Survey, Morgantown, WV, 844 p.

Hobba, W. A., 1991, Relation of Fracture Systems to Transmissivity of Coal and Overburden Aquifers in Preston County, West Virginia: U.S. Geological Survey Water-Resources Investigations Report 89-4137, 24 p.

Kendorski, F. S., 1993, Effect of high-extraction coal mining on surface and ground waters. In Proceedings, 12th International Conference on Ground Control in Mining, West Virginia University, Morgantown, WV, pp. 412-425.

Kipp, J. A. and Dinger, J. S., 1987, Stress-relief facture control of ground-water movements in the Appalachian Plateaus. Presented at the NWWA Focus Conference on Eastern Regional Ground-water Issues, July 1987, Burlington, VT, 6 p.

Kozar, M. D., and Mathes, M. V., 2001, Aquifer-Characteristics Data for West Virginia: U.S. Geological Survey Water-Resources Investigations Report 01-4036, 74 p.

Leavitt, B. R., 1999, Mine flooding and barrier pillar hydrology in the Pittsburgh basin. In Proceedings 16th Annual International Pittsburgh Coal Conference, Pittsburgh, PA.

Leavitt, B. R., Donovan, J. J., Morris, A. J., and Werner, E., 2003, Modeling of mine flooding in the Pittsburgh Coal Basin, USA. 6th ICARD, Cairns, Australia, July 2003, p. 1065-1071

Light, D. D. M., 2001, A Hydrogeological and Hydrogeochemical Characterization of the Truetown Mine Discharge: Unpublished M.S. Thesis, Department of Geological Sciences, Ohio University, Athens, OH, $271 \mathrm{p}$. 
Light, D. D. M., and Donovan, J. J., 2015, Mine-water flow between contiguous underground coal mines with hydraulically compromised barriers: Environmental \& Engineering Geoscience, Vol. 21, No. 2, pp. 147-164.

Matetic, R. J.; Liu, J.; and Elsworth, D., 1995, Modeling the effects of longwall mining on the ground water system: U. S. Bureau of Mines Report of Investigations 9516, 14 p.

McCoy, K. J., 2002, Estimation of Vertical Infiltration into Deep Pittsburgh Coal Mines of WVPA: A Fluid Mass Balance Approach: Unpublished M.S. Thesis, Department of Geology and Geography, West Virginia University, Morgantown, WV, 151 p.

McCoy, K. J.; Donovan, J. J.; and Leavitt, B. R., 2006, Horizontal hydraulic conductivity estimates for intact coal barriers between closed underground mines: Environmental \& Engineering Geoscience, Vol. 12, No. 3, pp. 273-282.

McDonough, K. M.; Lambert, D. C.; Mugunthan, P.; and Dzombak, D. A., 2005, Hydrologic and geochemical factors governing chemical evolution of discharges from an abandoned, flooded, underground coal mine network: Journal of Environmental Engineering, Vol. 131, No. 4, pp. 643-650.

Miller, L., 2000, Warwick Coal Mines: Greene County, Pennsylvania, Rita Miller Publishing, $256 \mathrm{p}$.

Palchik, V., 2002, Influence of physical characteristics of weak rock mass on height of caved zone over abandoned subsurface coal mines: Environmental Geology, Vol. 42, No. 1, pp 92-101. 
Palchik, V., 2003, Formation of fractured zones in overburden due to longwall mining: Environmental Geology, Vol. 44, No. 1, pp. 28-38.

Peng, S. S., and Chiang, H. S., 1984, Longwall Mining: Wiley, New York, NY, 708 p.

Peng, S. S., 1986, Coal Mine Ground Control, 2nd Ed., John Wiley \& Sons, New York, NY, 491 p.

Peng, S. S., 2006, Longwall Mining, 2nd Ed., Department of Mining Engineering, West Virginia University, Morgantown, WV, $621 \mathrm{p}$.

Pigati, E. and Lopez, D. L., 1999, Effect of subsidence on recharge at abandoned mines generating acidic drainage: the Majestic Mine, Athens County, $\mathrm{OH}$ : Mine Water and the Environment, Vol. 18, No. 1, pp. 45-66.

Rossi, T., 1999, Chapter 43 Climate, In C. H. Shultz (Editor), The Geology of Pennsylvania: Pennsylvania Geological Survey, Harrisburg and Pittsburgh Geological Survey, Pittsburgh, PA, 888 p.

Sahu, P., and Lopez, D. L., 2009, Using time series analysis of coal mine hydrographs to estimate storage, retention time, and mine-pool interconnection: Mine Water and the Environment, Vol. 28, No. 3, pp. 194-205.

Schubert, J. P., 1980, Fracture-flow of groundwater in coal-bearing strata, In Graves, D. H. and De Vore, R. W. (Editors) Proceedings of the Symposium on Surface Mining Hydrology, Sedimentology, and Reclamation: University of Kentucky, Lexington, KY. pp 61-73. 
Singh, M. M. and Kendorski, F. S., 1981, Strata disturbance prediction for mining beneath surface water and waste impoundments. In Proceedings of the 1st Conference on Ground Control in Mining: West Virginia University, Morgantown, WV, pp. 76-89.

Smith, M. W., 1986, Evaluating ground-water recharge in the Valley and Ridge region of the Central Appalachians using a digital-overlay technique, M. S. Thesis, Pennsylvania State University, University Park, PA, 289 p.

Stoertz, M. W.; Hughes, M. L.; Wanner, N. S.; and Farley, M. E., 2001, Long-term water quality trends at a sealed, partially flooded underground mine. Environmental \& Engineering Geoscience, Vol. 12, No. 1, pp. 51-65.

Stoner, J. D., 1983, Probable hydrologic effects of subsurface mining: Groundwater Monitoring Review, Vol. 3, No. 1, pp 128-137.

Stoner, J. D.; Williams, D. R.; Buckwalter, T. K.; Felbinger, J. K.; and Pattison, K. L., 1987, Water Resources and the Effects of Coal Mining, Greene County, Pennsylvania, Water Resource Report 63, Pennsylvanian Geological Survey, 4th Series, 166 p.

Williams, D. R.; Felbinger, J. K.; and Squillace, P. J., 1993, Water Resources and the Hydrologic Effects of Coal Mining in Washington County, Pennsylvania, U.S. Geological Survey Open File Report 89-620, 242 p.

Whitworth, K. R., 2002, The monitoring and modelling of mine water recovery in UK coalfields. In Younger, P. L., and Robins, N. S. (Editors), Mine Water Hydrogeology and 
Geochemistry. Geological Society of London Special Publication 198, London, UK, pp. $61-73$.

Winters, R. W., Capo, R. C., Wolinsky, M. W., Weaver, T. J., and Hedin, R. S, 1999, Geochemical and hydrogeologic evolution of alkaline discharges from abandoned coal mines. In Proceedings of the 16th Annual International Pittsburgh Coal Conference: University of Pittsburgh, Pittsburgh, PA, pp. 1-36.

Winters, R. W., and Capo, R. C., 2004, Ground water flow parameterization of an Appalachian coal mine complex. Groundwater, Vol. 42, No. 5, pp. 700-710.

Wunsch, D. R., 1993, Ground-water Geochemistry and its Relationships to the Flow System at an Unmined Site in the Eastern Kentucky Coal Field: Ph.D. Thesis, University of Kentucky, Kentucky Geological Survey, Thesis Series 5, Lexington, KY. 135 p.

Wyrick, G. G., and Borchers, J. W., 1981, Hydrologic Effects of Stress-Relief Fracturing in an Appalachian Valley, U.S. Geological Survey Water-Supply Paper 2177, 51 p.

Younger, P. L., and Adams, R., 1999, Predicting Mine Water Rebound, Environment Agency R \& D Technical Report W179, Bristol, UK, 109 p. 